\title{
Wnt signaling in breast cancer: biological mechanisms, challenges and opportunities
}

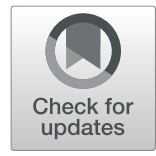

\author{
Xiufang $\mathrm{Xu}^{1+}$, Miaofeng Zhang ${ }^{2+}$, Faying $\mathrm{Xu}^{1+}$ and Shaojie Jiang ${ }^{1 *}$ (D
}

\begin{abstract}
Wnt signaling is a highly conserved signaling pathway that plays a critical role in controlling embryonic and organ development, as well as cancer progression. Genome-wide sequencing and gene expression profile analyses have demonstrated that Wnt signaling is involved mainly in the processes of breast cancer proliferation and metastasis. The most recent studies have indicated that Wnt signaling is also crucial in breast cancer immune microenvironment regulation, stemness maintenance, therapeutic resistance, phenotype shaping, etc. Wnt/ $\beta$-Catenin, Wnt-planar cell polarity (PCP), and $\mathrm{Wnt}-\mathrm{Ca}^{2+}$ signaling are three well-established Wnt signaling pathways that share overlapping components and play different roles in breast cancer progression. In this review, we summarize the main findings concerning the relationship between Wnt signaling and breast cancer and provide an overview of existing mechanisms, challenges, and potential opportunities for advancing the therapy and diagnosis of breast cancer.
\end{abstract}

Keywords: Canonical/noncanonical Wnt signaling, Breast cancer, Epithelial-mesenchymal transition, Drug resistance, Phenotype shaping, Immune microenvironment, Tumoral heterogeneity

\section{Background}

Breast cancer was the most commonly diagnosed cancer (24.2\% of the total cancer cases) and the leading cause of cancer-related death (15\% of the total cancer deaths) among females worldwide in 2018 [1]. Metastatic disease accounts for more than $90 \%$ of breast cancer-related deaths [2]. Increasing evidence suggests that the genetic mutation-driven activation of Wnt signaling is the key factor in breast cancer metastasis [3].

Wnt signaling is an evolutionarily conserved pathway in metazoan animals [4]. The name 'Wnt' is a fusion of the name of the vertebrate homolog Integrated (Int-1) $[5,6]$ and the name of the Drosophila segment polarity gene Wingless $[7,8]$. It has been almost four decades since the discovery of the Int-1 proto-oncogene, now known as $W n t-1$, which was identified as an integration site for mouse mammary tumor

* Correspondence: jsj1983@hmc.edu.cn

${ }^{+}$Xiufang $\mathrm{Xu}$, Miaofeng Zhang and Faying Xu contributed equally to this work.

${ }^{1}$ School of Medical Imaging, Hangzhou Medical College, Hangzhou 310053, Zhejiang, China

Full list of author information is available at the end of the article virus (MMTV) [5]. Breast cancer, on the other hand, is the first cancer to be associated with Wnt signaling.

In recent decades, a growing number of studies have demonstrated that Wnt signaling involves the proliferation [9], metastasis [3, 10,11], immune microenvironment regulation [3, 12], stemness maintenance [13], therapeutic resistance [14], and phenotype shaping [15, 16] of breast cancer. Various Wnt signaling inhibitors that act on different targets have been developed, and many of them exhibit potent anticancer potential [17]. However, no Wnt inhibitors have been approved for breast cancer treatment to date.

This review describes the three well-established Wnt signaling pathways, summarizes the main findings between Wnt signaling and breast cancer based on biological mechanisms, elaborates the challenges in drugging Wnt signaling, and provides potential solutions for both basic research and the clinical treatment of breast cancer.

\section{An overview of the Wnt signaling pathway}

There are $19 \mathrm{Wnt}$ genes in the human genome, all of which encode secreted lipoglycoproteins that have fundamental

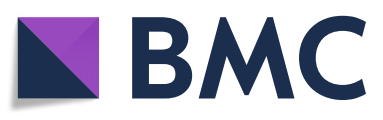

(C) The Author(s). 2020 Open Access This article is licensed under a Creative Commons Attribution 4.0 International License, which permits use, sharing, adaptation, distribution and reproduction in any medium or format, as long as you give appropriate credit to the original author(s) and the source, provide a link to the Creative Commons licence, and indicate if changes were made. The images or other third party material in this article are included in the article's Creative Commons licence, unless indicated otherwise in a credit line to the material. If material is not included in the article's Creative Commons licence and your intended use is not permitted by statutory regulation or exceeds the permitted use, you will need to obtain permission directly from the copyright holder. To view a copy of this licence, visit http://creativecommons.org/licenses/by/4.0/ The Creative Commons Public Domain Dedication waiver (http://creativecommons.org/publicdomain/zero/1.0/) applies to the data made available in this article, unless otherwise stated in a credit line to the data. 
roles in controlling cell specification, cell-cell interactions, stem cell self-renewal, and tissue patterning during embryonic development $[18,19]$. Wnt proteins (Wnts) couple to various receptors and thereby activate different downstream pathways [20]. Canonical Wnt signaling is a $\beta$-Catenindependent and $\mathrm{T}$ cell factor (TCF)/lymphoid enhancer factor (LEF)-involved pathway that is responsible mainly for breast cancer cell proliferation and 'stemness' maintenance [21]. Increasing evidence indicates that Wnt-PCP and Wnt- $\mathrm{Ca}^{2+}$ signaling, the two well-established $\beta$-Cateninindependent noncanonical Wnt pathways, are responsible for breast cancer cell metastasis [22, 23]. The processes of immune microenvironment regulation, therapeutic resistance, and phenotype shaping of breast cancer seem complicated and are always mediated by cooperation and crosstalk between canonical and noncanonical Wnt pathways.

\section{Canonical Wnt signaling pathway}

Canonical Wnt signaling (also known as Wnt/ $\beta$-Catenin signaling) is the best-characterized pathway and is generally triggered by Wnt1, Wnt2, Wnt3, Wnt3a, Wnt8b, Wnt10a, Wnt10b, and so on (Table 1) $[18,19,79]$. In the endoplasmic reticulum (ER), the conserved cysteine of Wnts is palmitoylated by Porcupine to a lipid-bound form that is also an active form [80]. The ER-to-Golgi trafficking of Wnts is mediated by the p24 protein family (such as TMED2/ CHOp24, TMED4/éclair, and TMED5/opossum) [81-83]. Then, lipid-modified Wnts are transported by GPR177 (also known as Wntless/Evenness/Interrupted/Sprinter) [84-87] in an endosome-dependent manner [88-90] and secreted into the extracellular matrix using exosomes as potent carriers [10,91-93]. Notum is a deacetylase that acts as a lipid eraser of Wnts and can inactivate Wnts [94, 95].

Frizzleds (Fzds) are 7-transmembrane (7-TM) proteins that act as the primary receptors for Wnts [96-98], while low-density lipoprotein receptor-related proteins (LRPs) are single-pass transmembrane proteins that act as coreceptors for Fzds [99-101]. Wnt signaling is inhibited by endogenous inhibitors, such as Wnt inhibitory factor 1 (WIF-1) [102], Cerberus [103], and secreted Fzd-related proteins (sFRPs) [104] that interact with Wnts directly, Wise/SOST [105-107] and dickkopf proteins (Dkks) [108, 109] that bind to LRPs and block Fzds-LRP heterodimer formation, and insulin-like growth factor-binding protein 4. (IGFBP4) physically interacts with Fzd8 and LRP6 and inhibits Wnt3a binding [110]. Of note, sFRPs can also interact with Fzds and inhibit Wnt signaling [111, 112]. Additionally, Rnf43 and Znrf3 are two single-pass transmembrane E3 ligases that specifically mediate the multiubiquitination of Fzds $[113,114]$.

Wnt signaling is maintained in an off state in the absence of extracellular Wnts. $\beta$-Catenin is the core component of canonical Wnt signaling and binds to the cytoplasmic tail of E-cadherin for cell-cell adhesion [115-118]. In the cytoplasm, $\beta$-Catenin is hijacked by the 'destruction complex', which comprises adenomatous polyposis coli (APC) $[119,120]$, Axin [121-124], glycogen synthase kinase $3 \beta$ (GSK-3 $\beta)$ [125, 126], casein kinase $1 \alpha(C K 1 \alpha)[127,128]$, protein phosphatase 2A (PP2A) [129], and Wilms tumor gene on X chromosome (WTX) [130], thereby being ubiquitinated by the Skp1, Cullin1 and F-box protein $\beta$ $\operatorname{TrCP}\left(\mathrm{SCF}^{\beta-\operatorname{TrCP}}\right)$ ubiquitin ligase and degraded $[131,132]$. $\beta$-Catenin is first phosphorylated by CK1 $\alpha$ at Ser45, followed by GSK-3 $\beta$ phosphorylation at the Thr41, Ser37, and Ser33 residues [90]. The phosphorylation of Ser33 and Ser37 creates the recognition site for $\beta$ - $\operatorname{TrCP}$ [127] for subsequent degradation. Tankyrase $1 / 2$ (TNKS1/2) destabilizes Axin, making it an attractive target for Wnt signaling regulation [133]. In addition, Siah-1 interacts with APC and promotes the degradation of $\beta$-Catenin independent of GSK- $3 \beta$-mediated phosphorylation and $\beta$-TrCP-mediated ubiquitin [134].

In the nucleus, TCF $[135,136]$ and C-terminal binding protein (CTBP) [137] interact with Transducin-like enhancer/Groucho (TLE/GRG), while histone deacetylases (HDACs) interact with TCF and LEF1 [138, 139]. These proteins form a repressor complex that represses the expression of Wnt target genes [140]. In addition, $\beta$-Catenin is inhibited from binding to TCF/LEF by inhibitors of $\beta$ Catenin and TCF (ICAT) [141] and Chibby (CBY) [142].

The canonical Wnt signaling cascade is initiated from the binding of lipid-modified Wnts to the receptor complex. Norrin binds to Fzd4 and activates the canonical Wnt pathway, although it is structurally unrelated to Wnts [143-145]. On the other hand, R-spondin binds to leucine-rich repeat-containing $G$ protein-coupled receptor 5 (LGR5) and induces the membrane clearance of Rnf43/ Znrf3, which removes the ubiquitylation of Fzd4 [113, 114]. LRP6 is phosphorylated by GSK-3 and CK1 [146, 147], which recruits the scaffold protein Axin [148], while Fzds recruit Dishevelled (Dvl) [149] to the plasma membrane, thereby disrupting the destruction complex [150].

$\beta$-Catenin is phosphorylated at Ser191 and Ser605 by Jun $\mathrm{N}$-terminal kinase 2 (JNK2), which facilitates its nuclear localization mediated by Rac1 [151]. In the nucleus, $\beta$ Catenin serves as a scaffold for the LEF $[152,153]$ and TCF [154-156] families, recruiting coactivators such as CREBbinding protein (CBP)/p300 [157], Pygopus (PYGO) and B cell lymphoma 9 (BCL9) $[158,159]$ and leading to the transcription of a large set of target genes (Fig. 1).

\section{Wnt-PCP signaling pathway}

Wnt-PCP signaling does not involve $\beta$-Catenin, LRP, or TCF molecules and is generally triggered by Wnt4, Wnt5a, Wnt5b, Wnt7b, and Wnt11 [160-162] (Table 1). These Wnts can also be inhibited by directly binding to endogenous inhibitors, including sFRPs, WIF, and 
Table 1 Wnt ligands and related factors in breast cancer

\begin{tabular}{|c|c|c|c|}
\hline Ligand & Signaling pathway & Alterations in breast cancer & Ref. \\
\hline$\overline{\text { Wnt1 }}$ & Canonical & $\begin{array}{l}\text { Activated by MMTV integration in breast cancer; } \\
\text { Activated by TP53 loss in breast cancer; } \\
\text { Highly expressed in breast cancer }\end{array}$ & {$[3,5,24-26]$} \\
\hline Wnt2 & Canonical & Expressed at a high level in breast cancer & [27-32] \\
\hline Wnt2b & Canonical & - & {$[33,34]$} \\
\hline Wnt3 & Canonical & $\begin{array}{l}\text { Overexpressed in trastuzumab-insensitive breast cancer cells; } \\
\text { Activated by TGF } \beta \text { in breast cancer cells }\end{array}$ & [35-37] \\
\hline Wnt3a & Canonical & Amplified in breast cancer & [16] \\
\hline Wnt4 & Noncanonical & Driven by estrogen and progesterone in breast cancer & {$[25,27,38,39]$} \\
\hline Wnt5a & Canonical/noncanonical & Highly expressed in BLBC & {$[15,16,22,40]$} \\
\hline Wnt5b & Canonical/noncanonical & Highly expressed in BLBC & {$[16,22,41-43]$} \\
\hline Wnt6 & Canonical & Activated by TP53 loss in breast cancer & [3] \\
\hline Wnt7a & Canonical/noncanonical & $\begin{array}{l}\text { Activated by TP53 loss in breast cancer; } \\
\text { Secreted exclusively by aggressive breast cancer cells }\end{array}$ & {$[3,44,45]$} \\
\hline Wnt7b & Canonical/noncanonical & Activated by TGF $\beta$ in breast cancer cells & {$[27,45,46]$} \\
\hline Wnt8a & Noncanonical & - & [47] \\
\hline Wnt8b & Canonical & - & [48] \\
\hline Wnt9a & Canonical & Amplified in breast cancer & {$[16,49]$} \\
\hline Wnt9b & Canonical/noncanonical & - & {$[50-52]$} \\
\hline Wnt10a & Canonical & $\begin{array}{l}\text { Expressed in mouse ALDH-negative breast cancer cells in } \\
\text { a time-dependent manner }\end{array}$ & [53] \\
\hline Wnt10b & Canonical & Highly expressed in TNBC & {$[9,54-56]$} \\
\hline Wnt11 & Canonical/noncanonical & Induced by ERa and $\beta$-Catenin & {$[57,58]$} \\
\hline Wnt16 & Canonical/noncanonical & - & [59-62] \\
\hline Porcupine & Canonical/noncanonical & - & [63] \\
\hline p24 proteins & Canonical/noncanonical & TMED2 is increased in breast cancer & [64] \\
\hline GPR177 & Canonical/noncanonical & Markedly increased in breast cancer & [65] \\
\hline Notum & Canonical/noncanonical & - & - \\
\hline Norrin & Canonical/noncanonical & Significantly decreased in breast cancer & [66] \\
\hline R-spondin & Canonical/noncanonical & R-spondin-1 is secreted by differentiated mammary luminal cells & {$[67,68]$} \\
\hline Cerberus & Canonical/noncanonical & - & - \\
\hline sFRPs & Canonical/noncanonical & $\begin{array}{l}\text { SFRP1, sFRP2, and SFRP5 are aberrantly methylated or epigenetically } \\
\text { suppressed in breast cancer }\end{array}$ & [69-74] \\
\hline WIF & Canonical/noncanonical & WIF-1 is epigenetically silenced or lost in breast cancer & {$[75,76]$} \\
\hline SOST & Canonical & Induced expression by Runx $2 / C B F \beta$ in metastatic breast cancer cells & [77] \\
\hline Dkks & Canonical/noncanonical & Dkk1 is epigenetically inactivated in breast cancer & [69] \\
\hline IGFBP4 & Canonical & Protease-resistant IGFBP4 is expressed in murine breast cancer & [78] \\
\hline
\end{tabular}

Cerberus, and sFRPs may also inhibit Wnt-PCP signaling by binding to Fzds [163].

The complementary and mutually exclusive distribution of transmembrane complexes is the key feature of planar polarization, which results in the asymmetric enrichment of proximal and distal transmembrane complexes in cells (Fig. 2a). The proximal transmembrane complex is composed of Vang-like 2 (Vangl2), cadherin EGF LAG seven-pass G-type receptor 1 (Celsr1), Prickle, inturned (Intu) and Dvl [164], while the distal transmembrane complex is composed of Fzds,
Celsr1, Inversin (Invs) and Dvl. On the proximal side, Vangl2 recruits Prickle, which competes with Invs for Dvl binding and therefore disrupts the localization of Invs towards the proximal side. Intriguingly, noncanonical Wnt binding to Fzds leads to Dvl phosphorylation and distal side localization of the Invs [165] and DvlPar6 complex, and Smurf is recruited by phosphorylated Dvl to Par6, thereby ubiquitinating and degrading Par6bound Prickle on the distal side and antagonizing the inhibitory action of Prickle on Wnt-PCP signaling [166] (Fig. 2b). This asymmetric cell patterning, in turn, directs 


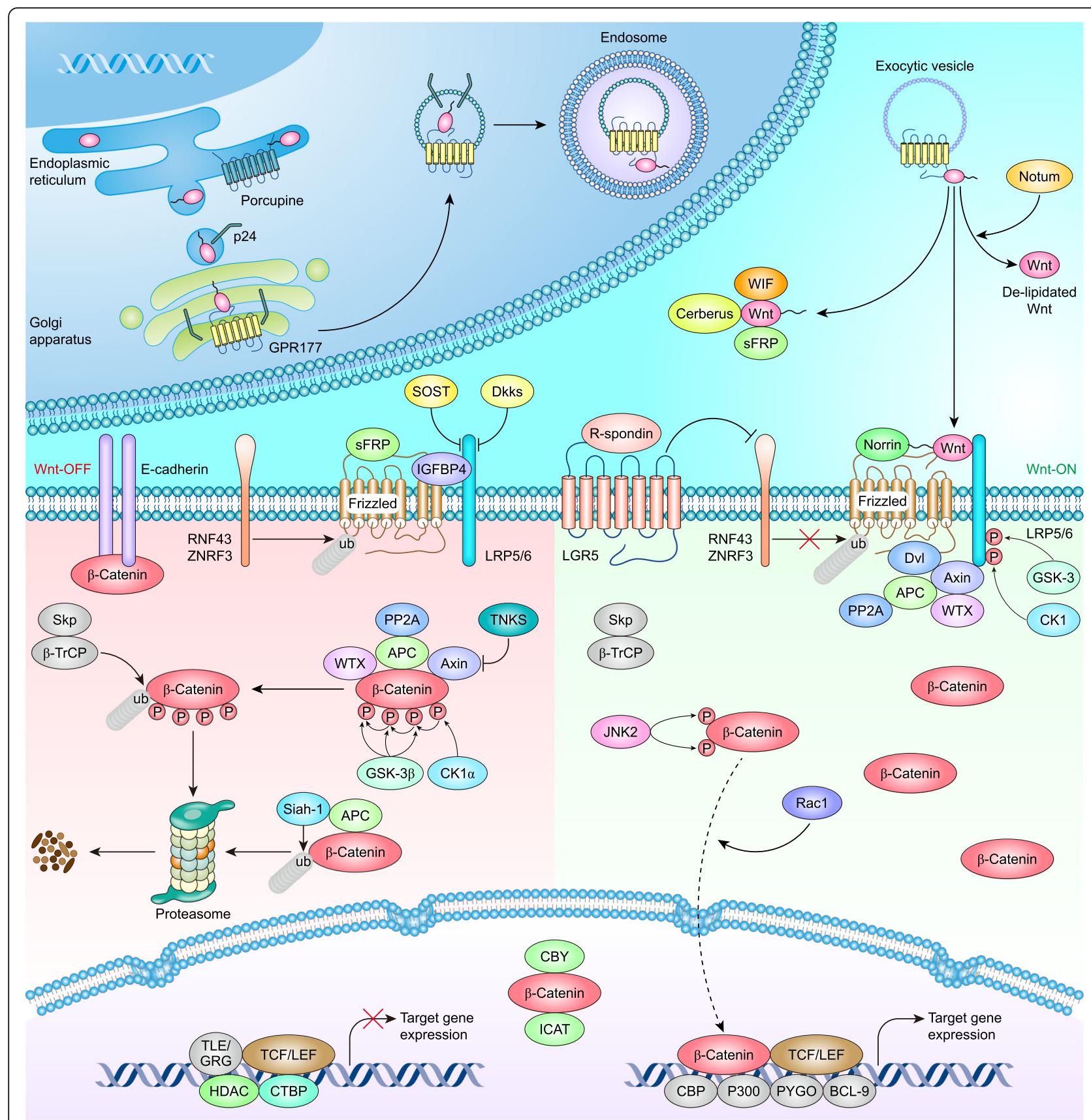

Fig. 1 Canonical Wnt signaling pathway in mammals

the orientation of subcellular structures and cell behaviors through the regulation of cytoskeletal elements and cellular adhesions [161].

Fzds [167-170], Celsr1 [171-173], and Vangl2 [174-179] are core receptors in Wnt-PCP signaling. Fzds are still the primary receptors for Wnts, while receptor-like tyrosine kinase (RYK) [180], muscle-skeletal receptor Tyr kinase (MUSK) [181-183], protein tyrosine kinase 7 (PTK7) [184], receptor Tyr kinase-like orphan receptor $1 / 2$ (ROR1/2) [162], Syndecan [185, 186] and Glypican [187] act as coreceptors for Fzds. However, the ligand-receptor binding interaction between Wnts and Celsr1 [188] or Vangl2 [189] has not been clarified to date.

The formation of the Fzds-Celsr1-Invs-Dvl complex and the interaction between Dvl and Dvl-associated activator of morphogenesis (DAAM) activate the small GTPases Rac1 [190] and Ras homologue gene-family member A (RHOA) [191, 192]. Rac1 activates JNK [193], which further phosphorylates c-Jun at Ser63 and Ser73, thereby activating c-Jun [194]. RHOA subsequently activates diaphanous 1 


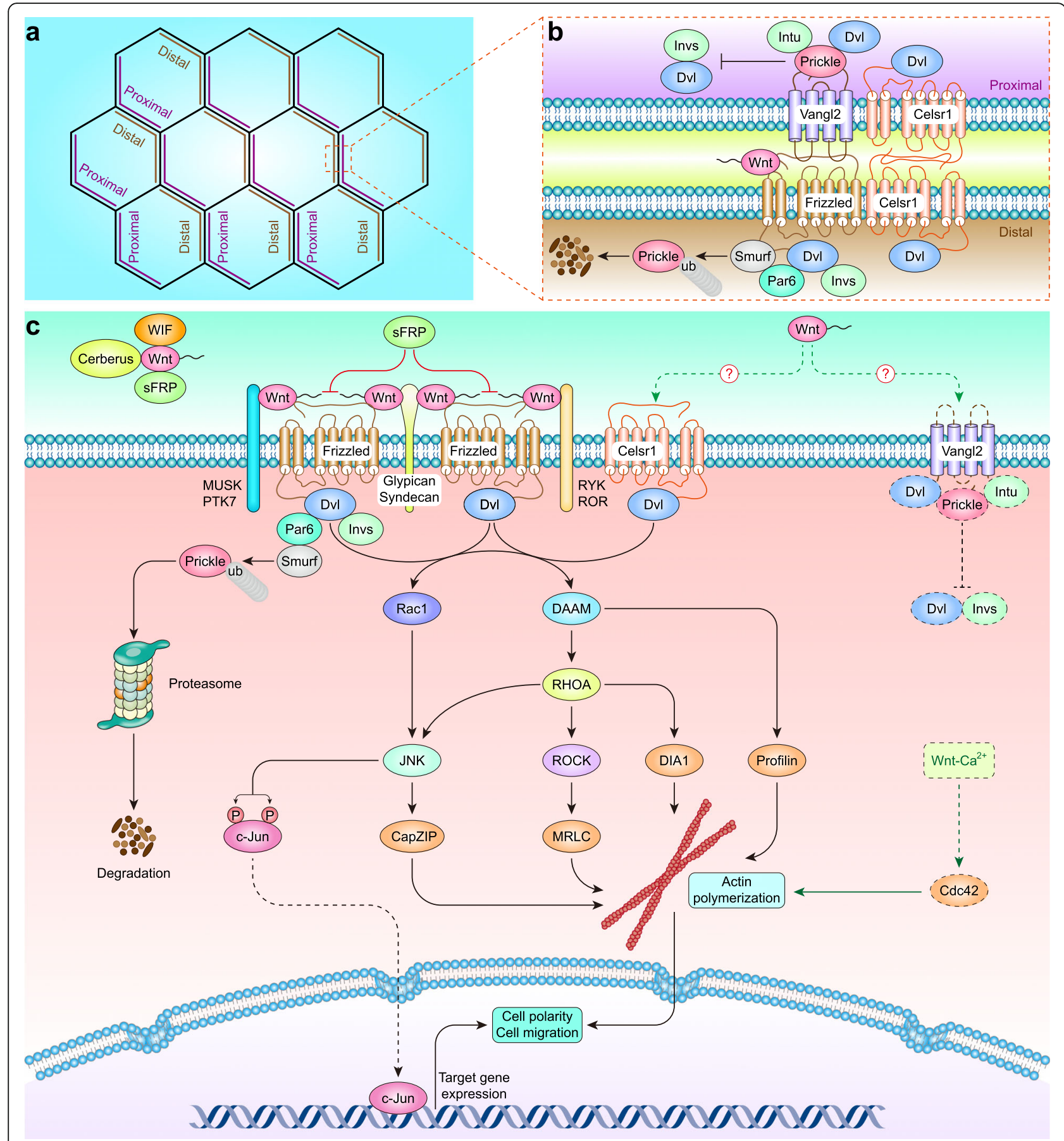

Fig. 2 Wnt-PCP signaling pathway in mammals. a Planar cell polarity of the asymmetric transmembrane complexes. b Asymmetric PCP signaling components form transmembrane complexes. c Wnt-PCP signaling pathway in mammals

(DIA1) and RHO-associated coiled-coil-containing protein kinase (ROCK) [195]. Then, JNK activates CapZ-interacting protein (CapZIP) [196], ROCK activates mitogen-activated protein kinase (MRLC) [197], and DAAM activates Profilin [198]. These PCP effectors lead to the development of lateral asymmetry in epithelial sheets and other structures
[199], as well as cell polarity and migration by remodeling the cytoskeleton [200] (Fig. 2c).

\section{Wnt- $-\mathrm{Ca}^{2+}$ signaling pathway}

Wnt- $\mathrm{Ca}^{2+}$ signaling is a less focused noncanonical Wnt pathway but plays a central role in cell fate during early embryogenesis [201], cancer progression [202-204], interneural 
communication [205], the inflammatory response [206], and so on. Wnt $-\mathrm{Ca}^{2+}$ signaling is initiated mostly by Wnt5a and Fzd2, and pertussis toxin-sensitive heterotrimeric $G$ protein subunits [207] are required for the activation of phospholipase C (PLC). Activated PLC cleaves phosphatidylinositol-4, 5-bisphosphate (PtdInsP $\mathrm{P}_{2}$ ), a membrane-bound inositol lipid, into diacylglycerol (DAG) and inositol-1,4,5-trisphosphate $\left(\mathrm{InsP}_{3}\right)$. DAG, together with $\mathrm{Ca}^{2+}$, activates protein kinase $\mathrm{C}(\mathrm{PKC})$, which further stimulates cell-division cycle 42 (Cdc42) and promotes actin polymerization. On the other hand, InsP $\mathrm{P}_{3}$ binds to inositol-1,4,5-trisphosphate receptors (InsP ${ }_{3} \mathrm{Rs}$ ) [208] on the ER membrane, opening calcium channels for $\mathrm{Ca}^{2+}$ release and increasing cytoplasmic $\mathrm{Ca}^{2+}$ levels [209]. The decrease in $\mathrm{Ca}^{2+}$ levels within the ER lumen is sensed by stromal interaction molecule $1 / 2$ (STIM1/2), which gains an extended conformation to trap and activate ORAI proteins at the plasma membrane and induce store-operated $\mathrm{Ca}^{2+}$ entry (SOCE) $[210,211]$. In addition, sarcoplasmic/ER $\mathrm{Ca}^{2+}$ ATPases (SERCAs) act as $\mathrm{Ca}^{2+}$ ion pumps that pump $\mathrm{Ca}^{2+}$ from the cytosol to the ER. An increased $\mathrm{Ca}^{2+}$ concentration activates the phosphatase calcineurin and several calcium-dependent kinases, including PKC and calcium calmodulin mediated kinase II (CAMKII). The increased activity of calcineurin, in turn, activates the nuclear factor of activated T cells (NFAT) [212]. In contrast, CAMKII stimulation activates TGF $\beta$-activated protein kinase 1 (TAK1), which subsequently activates nemo-like kinase (NLK), resulting in the phosphorylation of TCF and the inhibition of $\beta$-Catenin/TCF signaling [213, 214]. The Wnt-Fzd-Dvl complex also activates cyclic guanosine monophosphate (cGMP)-specific phosphodiesterase 6 (PDE6), thereby depleting cellular cGMP and inactivating protein kinase G (PKG), which in turn increases the cellular concentration of $\mathrm{Ca}^{2+}$. The $\mathrm{G}$ protein-induced activation of $\mathrm{p} 38$ via mitogen-activated protein kinase 3/6 (MKK3/6) is required for the activation of PDE6. Moreover, the p38-induced phosphorylation of activating transcription factor 2 (ATF2) on Thr69 and Thr71 is important for its transcription [215, 216] (Fig. 3).

\section{Wnt signaling alterations in breast cancer}

Numerous studies have shown that the constitutive components of Wnt signaling are altered in breast cancer cells. These alterations include mutations, amplifications, deletions, and methylations that occur at the DNA level, posttranscriptional modifications that occur at the mRNA level, and posttranslational modifications that occur at the protein level. These alterations also include changes in subcellular localization, especially for $\beta$-Catenin. Mutation of CTNNB1, which encodes $\beta$-Catenin, is rare in breast cancer [217]. However, the activation of Wnt signaling is nonetheless thought to play an essential role in breast tumorigenesis [69]. This is mainly due to the epigenetic activation of Wnts and the inactivation of Wnt inhibitors (Table 1). Nonetheless, it has been reported that Wnt5a is lost in breast cancer [75, 218-220]. Foxy-5, a Wnt5a mimicking hexapeptide, impairs the migration and invasion of breast cancer without affecting apoptosis or proliferation by reconstituting Wnt5a signaling [221] and has entered phase I clinical trials (NCT02020291 and NCT02655952) for metastatic breast, colorectal and prostate cancer treatment and a phase II clinical trial (NCT03883802) for Wnt5a-low colon cancer neoadjuvant therapy. In addition, most canonical and noncanonical Wnt receptors are elevated in breast cancer, especially in triple-negative breast cancer (TNBC) and basal-like breast cancer (BLBC). Ecadherin, as an interacting protein of $\beta$-Catenin, is frequently mutated or silenced in BLBC and TNBC, which leads to the release of $\beta$-Catenin from the cytomembrane into the cytoplasm [222-224] (Table 2).

Cytoplasmic $\beta$-Catenin should be carefully controlled by the destruction complex in the cytoplasm. However, the destruction complex components are frequently mutated, deleted, hypermethylated, or reduced in breast cancer, which increases the stability of cytoplasmic $\beta$-Catenin and the probability of $\beta$-Catenin entering the nucleus. Most coactivators are highly expressed in breast cancer, as expected. However, it is interesting that some corepressors (e.g., TLE/ GRG and CTBP) are elevated in breast cancer [254, 255] (Table 3). These studies suggest that the activation of canonical Wnt signaling in breast cancer is induced mainly by epigenetic alterations in the constitutive components rather than the mutation of $\beta$-Catenin or APC. Noncanonical Wnt signaling is preferentially activated in TNBC/BLBC and is induced mainly by the epigenetic activation of noncanonical Wnts and their receptors (Tables 1 \& 2). Cytoplasmic components of noncanonical Wnt signaling are commonly involved in various signaling pathways and are challenging to define as exclusive components of noncanonical Wnt signaling (Figs. $2 \& 3$ ).

\section{Wnt signaling in breast cancer classification}

Invasive ductal carcinoma no-special-type (IDC-NST) and invasive lobular carcinoma (ILC) are the most common histological subtypes of breast carcinoma, accounting for $70 \sim 75 \%$ and $10 \sim 14 \%$, respectively [272]. $\beta$-Catenin expression is significantly correlated with histological type. The majority of IDCs display a regular pattern of $\beta$-Catenin expression, with membranous expression (80.6\%) and nuclear expression (12.5\%), whereas ILCs lack membranous expression (14.7\%) and nuclear expression (0\%) [256]. Additionally, E-cadherin and $\beta$-Catenin expression is largely preserved in ductal carcinoma in situ (DCIS) [273]. However, lobular carcinoma in situ (LCIS) shows the simultaneous loss of E-cadherin and $\beta$-Catenin expression [274]. This may explain why IDCs have a worse prognosis than ILCs [275] (Fig. 4a). 


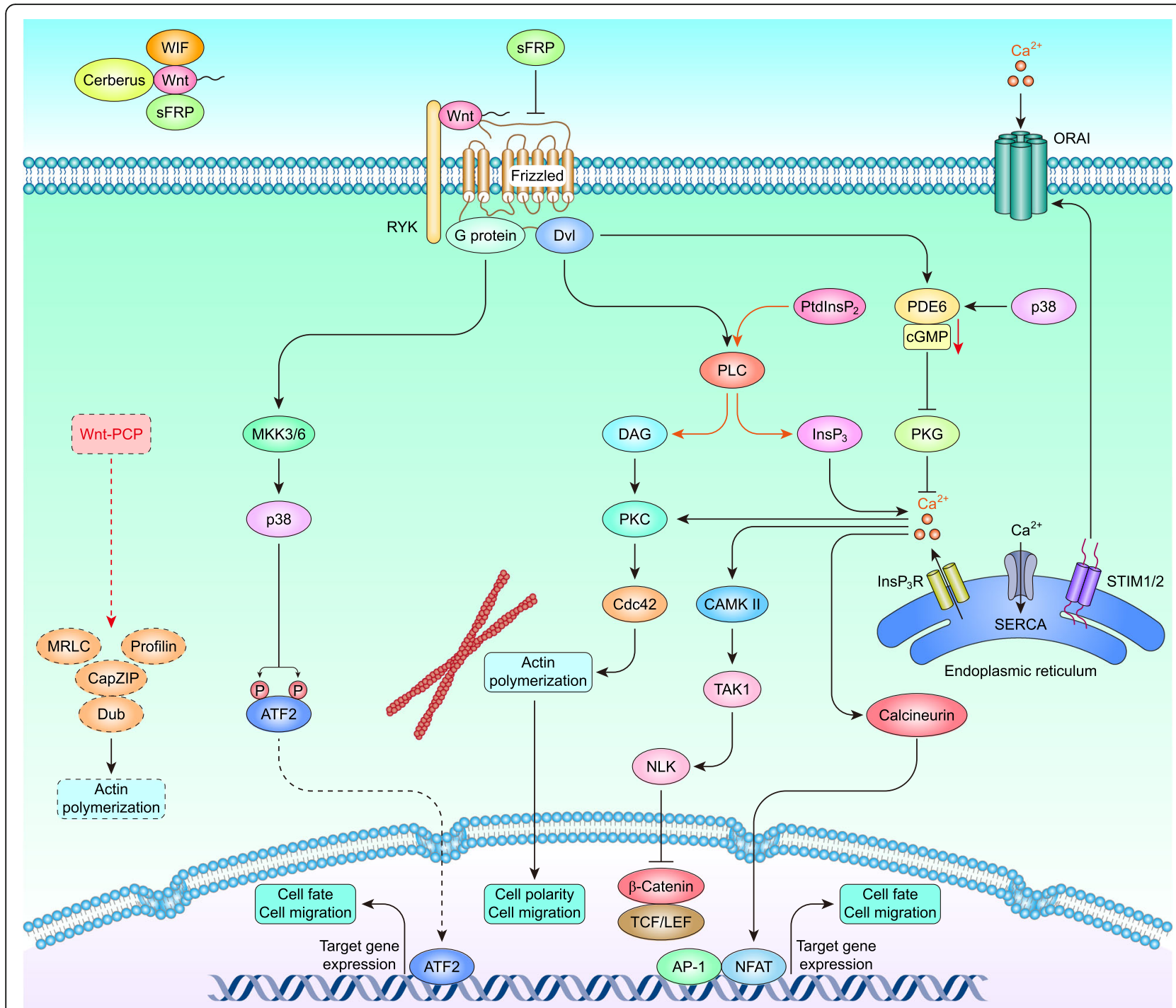

Fig. 3 Wnt-Ca ${ }^{2+}$ signaling pathway in mammals

Furthermore, breast cancer can be classified into five intrinsic subtypes: luminal A, luminal B, Her-2 enriched, normal-like, and BLBC [276-278]. However, the normallike subtype is controversial, potentially due to normal tissue contamination and low tumor cellularity [279]. Claudin-low was initially considered a breast cancer subtype $[280,281]$ and later redefined as a breast cancer phenotype [282].

Surrogate intrinsic subtypes are based on the immunohistochemistry of estrogen receptor (EsR), progesterone receptor $(\mathrm{PgR})$, human epidermal growth factor receptor 2 (Her-2), and Ki67 and consist of luminal A-like, luminal B-like, Her-2 enriched, and TNBC [283]. The majority of BLBCs and claudin-low intrinsic subtypes are TNBCs [272, 284]. TNBCs can be further divided into basal-like 1 (BL-1), basal-like 2 (BL-2), immunomodulatory (IM), luminal androgen receptor (LAR), mesenchymal (M), and mesenchymal stem-like (MSL) [285].

The claudin-low subtype is composed mostly of the M and MSL subtypes of TNBC [286], which, together with the BL-2 subtype of TNBC, are linked to Wnt signaling activation [285]. Intriguingly, the majority of claudin-low cancers are metaplastic breast cancers [281]. This is consistent with the previous description that Wnt signaling activation is enriched in metaplastic breast cancers [287], BLBCs [257], and TNBCs [256]. Specifically, Wnt signaling activation in metaplastic breast cancers is caused mainly by genetic changes, such as CTNNB1 and APC mutations [287], whereas Wnt signaling activation in BLBCs and TNBCs is associated mainly with the strong expression of nuclear $\beta$ Catenin $[256,257]$. This may be the main reason for the worst prognosis of TNBCs among all subtypes. Notably, 
Table 2 Wnt receptors and coreceptors in breast cancer

\begin{tabular}{|c|c|c|c|}
\hline Receptor & Signaling pathway & Alterations in breast cancer & Ref. \\
\hline$\overline{\text { Fzd1 }}$ & Canonical & Upregulated in breast cancer & {$[225,226]$} \\
\hline Fzd2 & Noncanonical & Elevated in metastatic breast cancer & {$[22,225]$} \\
\hline Fzd3 & - & - & - \\
\hline Fzd4 & - & - & - \\
\hline Fzd5 & - & - & - \\
\hline Fzd6 & Noncanonical & Genomically amplified in TNBC & [227] \\
\hline Fzd7 & Canonical & Elevated in BLBC/TNBC & [228-230] \\
\hline Fzd8 & - & - & - \\
\hline Fzd9 & - & Relatively hypermethylated in breast cancer & [231] \\
\hline Fzd10 & - & - & - \\
\hline LRP5 & Canonical & - & - \\
\hline LRP6 & Canonical & $\begin{array}{l}\text { Markedly upregulated in breast cancer; } \\
\text { Overexpressed in TNBC }\end{array}$ & {$[229,232]$} \\
\hline RNF43 & Canonical & - & - \\
\hline ZNRF3 & Canonical & - & - \\
\hline E-cadherin & Canonical & Mutated or silenced in $\mathrm{BLBC} / \mathrm{TNBC}$ & [222-224] \\
\hline LGR5 & Canonical & Overexpressed in breast cancer & {$[233,234]$} \\
\hline Celsr1 & Noncanonical & Highly expressed in luminal breast cancer & [235] \\
\hline Vangl2 & Noncanonical & Highly expressed in BLBC & [189] \\
\hline ROR1 & Noncanonical & $\begin{array}{l}\text { Highly expressed in TNBC, BLBC, and } \\
\text { aggressive/metastasis-prone breast cancer }\end{array}$ & [236-240] \\
\hline ROR2 & Canonical/noncanonical & Highly expressed in breast cancer & [241] \\
\hline RYK & Noncanonical & Reduced in primary breast cancer & [220] \\
\hline PTK7 & Noncanonical & Elevated in TNBC and BLBC & [242-244] \\
\hline MUSK & Noncanonical & - & - \\
\hline Syndecan & Noncanonical & $\begin{array}{l}\text { Syndecan-1 is overexpressed in breast cancer; } \\
\text { Induced expression in stromal fibroblasts of breast cancer }\end{array}$ & [245-248] \\
\hline Glypican & Noncanonical & Glypican-3 is silenced in human breast cancer & [249] \\
\hline ORAI & Noncanonical & $\begin{array}{l}\text { ORAI1 is elevated in BLBC; } \\
\text { ORAI3 is elevated in breast cancer }\end{array}$ & {$[250-253]$} \\
\hline
\end{tabular}

both basal and luminal tumor cells are found in MMTVWnt1 mammary tumors, implying that they are derived from a bipotent malignant progenitor cell [24, 288]. Based on these studies, Wnt signaling is the critical pathway for phenotype shaping in both histological subtypes and molecular subtypes of breast cancer (Fig. $4 \mathrm{~b}$ ).

\section{Wnt signaling in the breast cancer immune microenvironment}

All breast cancers arise in the terminal duct lobular units (the functional unit of the breast) of the collecting duct [272] (Fig. 5 a). Breast cancer cells commonly reside in a complicated tumor microenvironment that is composed mainly of genetically abnormal cells surrounded by blood vessels, fibroblasts, immune cells, stem cells and the extracellular matrix (ECM), and dynamic crosstalk among these various components ultimately determines the fate of breast cancer [289] (Fig. 5 b).

The reciprocal crosstalk between breast cancer cells and immune cells is initiated by the neoantigens [272] that arise from nonsynonymous mutations and other genetic alterations [290]. These neoantigens are presented by antigen-presenting cells (APCs) on major histocompatibility complex class I (MHC I) or MHC II molecules [272], resulting in the activation of $\mathrm{CD}^{+}$ (cytotoxic) [291] and $\mathrm{CD}^{+}$(helper) T cells [292]. Activated $\mathrm{CD}^{+} \mathrm{T}$ cells directly induce premalignant breast cell lysis by releasing cytolytic perforin and granzyme B [293] and promote the apoptosis of premalignant breast cells by expressing Fas ligand (FasL) and TNF-related apoptosis-inducing ligand (TRAIL) on their cell surface [272, 294]. This may explain why high breast tumorinfiltrating $\mathrm{CD}^{+} \mathrm{T}$ cell counts are associated with 
Table $3 \beta$-Catenin and its related factors in breast cancer

\begin{tabular}{|c|c|c|c|}
\hline Protein & Function & Alterations in breast cancer & Ref. \\
\hline$\beta$-Catenin & Key mediator & $\begin{array}{l}\text { Increased nuclear accumulation in TNBC and BLBC; } \\
\text { Activation is enriched in BLBC }\end{array}$ & {$[256,257]$} \\
\hline APC & Destruction complex & Mutated, deleted, hypermethylated or reduced in breast cancer & [258-262] \\
\hline PP2A & & Reduced activity in breast cancer & [263] \\
\hline WTX & & Reduced in breast cancer & [264] \\
\hline Axin & & Mutated in breast cancer & [265] \\
\hline GSK-3ß & & Reduced in BLBC cells & [16] \\
\hline CK1a & & Reduced in BLBC cells & [16] \\
\hline Siah-1 & & - & - \\
\hline TNKS & Destabilizer of Axin & Overexpressed in breast cancer & [266] \\
\hline JNK2 & Transcriptional cofactor & - & - \\
\hline Rac1 & & Mutated and overexpressed in breast cancer & [267] \\
\hline TLE/GRG & Corepressor & TLE1 is selectively upregulated in invasive breast cancer & [254] \\
\hline HDAC & & - & - \\
\hline СТВP & & Elevated in TNBC and BLBC & [255] \\
\hline CBY & & - & - \\
\hline ICAT & & - & - \\
\hline TCF & Coactivator & TCF1/7 is overexpressed in BLBC cells & [16] \\
\hline LEF & & LEF1 is highly expressed in Her-2-negative breast cancer & [268] \\
\hline CBP & & - & - \\
\hline P300 & & Highly expressed in breast cancer & [269] \\
\hline PYGO & & PYGO2 is highly expressed in breast cancer cells & [270] \\
\hline$B C L-9$ & & Significantly amplified in BLBC & [271] \\
\hline
\end{tabular}

improved clinical outcomes [295]. CD $4^{+} \mathrm{T}_{\mathrm{H}} 1$ cells arise from naive $\mathrm{T}$ cells that are activated by interleukin (IL)12 (provided by dendritic cells and macrophages) and interferon (IFN)- $\gamma$ (provided by natural killer (NK) cells) [296] and amplify the anticancer effect of $\mathrm{CD}^{+} \mathrm{T}$ cells by secreting IFN- $\gamma$, IL-2, and tumor necrosis factor (TNF)- $\alpha$. NK T cells recognize MHC I-like molecule CD1d on dendritic cells and are further activated by IL12 that is expressed by dendritic cells. Activated NK T cells also recognize CD1d expressed by breast cancer cells [297] and recruit NK cells by releasing IFN- $\gamma$, which kills breast cancer cells directly (Fig. 5 c).

However, Wnt/ $\beta$-catenin signaling activation suppresses the antitumor immune response [298]. Malignant breast cells with activated Wnt signaling develop several strategies to avoid immune recognition and destruction. They express CD24 [299] and CD47 [300302] as 'don't eat me' signals to prevent phagocytosis from macrophages by interacting with Siglec-10 and SIRP- $\alpha$, respectively, expressed by macrophages. Remarkably, CD24 is a direct target of Wnt1 in breast cancer [303], while CD47 is an indirect target of Wnt signaling mediated by SNAI1 and ZEB1 in breast cancer [304]. In addition, CD47 and programmed death-ligand
1 (PD-L1) are controlled by $M y c$, a well-documented target of Wnt/ $\beta$-catenin signaling [305]. In addition, TNBCs upregulate PD-L1 through Wnt signaling activity, thereby blocking $\mathrm{CD}^{+} \mathrm{T}$ cell activation [306]. Cytotoxic T lymphocyte antigen 4 (CTLA-4) is expressed at a low level in naive $\mathrm{T}$ cells but is rapidly induced after activation. Coincidentally, CTLA-4 is also a direct target of Wnt $/ \beta$-catenin signaling [307]. Tumor-associated macrophages (TAMs) [308] and forkhead box protein P3 (FoxP3) ${ }^{+} \mathrm{T}_{\text {reg }}$ cells [309-311] are commonly associated with a poor clinical outcome. TAMs directly inhibit $\mathrm{T}$ cell functions by expressing checkpoint ligands (such as PD-L1, PD-L2, B7-1/CD80, and B7-2/CD86) [312] and inhibit $\mathrm{CD}^{+} \mathrm{T}_{\mathrm{H}} 1, \mathrm{~T}_{\mathrm{H}} 2$, and $\mathrm{CD} 8^{+} \mathrm{T}$ cells by secreting immunosuppressive cytokines (such as IL-10 and TGF $\beta$ ) [313]. TAMs also inhibit cytotoxic $\mathrm{T}$ cells by releasing arginase 1 and indoleamine 2,3-dioxygenase (IDO). In addition, TAMs secrete Wnt7b, which mediates the angiogenic switch and metastasis in breast cancer [46]. FoxP3 $^{+} \mathrm{T}_{\text {reg }}$ cells exert their immunosuppressive effect by consuming IL-2, secreting immunosuppressive cytokines (such as IL-10, IL-35, and TGF $\beta$ ), converting ATP into adenosine, and secreting perforin and/or granzyme $\mathrm{B}$, thereby limiting, inhibiting or destroying effector cells 


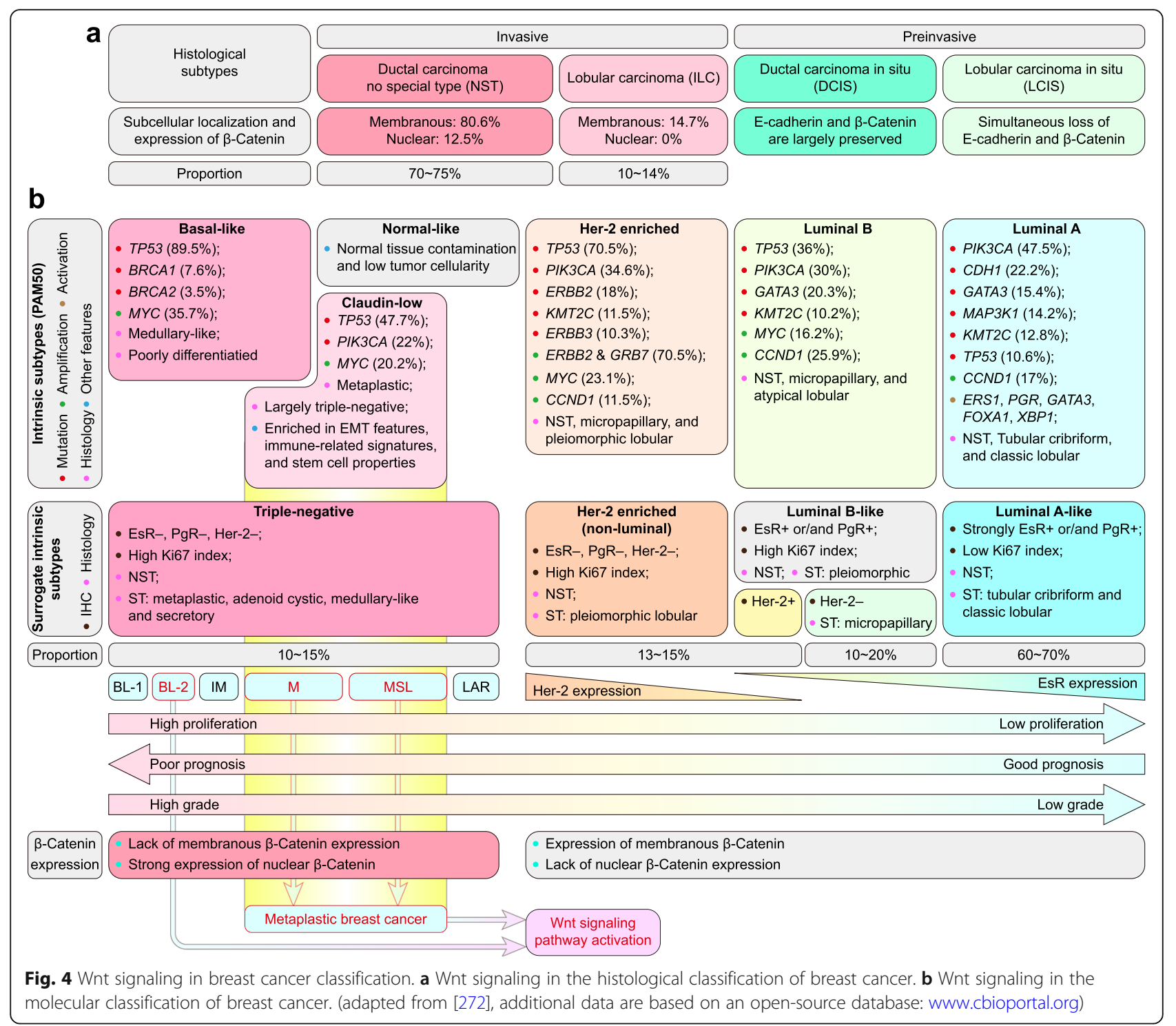

and attenuating the functions of APCs mediated by CTLA-4 [314]. Intriguingly, TAMs and FoxP3 ${ }^{+} \mathrm{T}_{\text {reg }}$ cells express IL-10 and TGF $\beta$, which induces reciprocal activation. Based on these studies, atezolizumab, an antiPD-L1 monoclonal antibody, has been approved by the Food and Drug Administration (FDA) for advanced or metastatic TNBC with PD-L1 expression [315]. T cell exhaustion mediated by Wnt signaling is a strategy that was developed for the immune escape of malignant breast cells (Fig. $5 \mathrm{~d}$ ).

TP53 is the most frequently altered gene in metastatic breast cancers [316]. The loss of TP53 in breast cancer cells triggers the secretion of Wnt1, Wnt6, and Wnt7a. These Wnts bind to Fzd7 and Fzd9 on the surface of TAMs, stimulating TAMs to produce IL- $1 \beta$ [3]. IL-1 $\beta$ elicits IL-17 expression from $\gamma \delta \mathrm{T}$ cells, resulting in the systemic, granulocyte colony-stimulating factor (G-CSF)- dependent expansion and polarization of neutrophils. Phenotypically altered neutrophils produce inducible nitric oxide synthase (iNOS), which suppresses the activity of antitumor $\mathrm{CD}^{+} \mathrm{T}$ cells and thereby induces systemic inflammation and drives breast cancer metastasis [317]. FoxP3 $^{+} \mathrm{T}_{\text {reg }}$ cells express receptor activator of nuclear factor- $\mathrm{kB}$ (RANK) ligand (RANKL), which stimulates the pulmonary metastasis of $\mathrm{RANK}^{+}$breast cancer cells [318]. Cancer-associated fibroblasts (CAFs) promote tumor immunosuppression by releasing IL-6, which increases the number of FoxP3 ${ }^{+} \mathrm{T}_{\text {reg }}$ cells [319]. Malignant breast cells acquire invasive properties and become invasive breast cancer cells through an epithelialmesenchymal transition (EMT)-dependent process that is mediated mostly by the Wnt signaling pathway [320323] (see below). FoxP3 ${ }^{+} \mathrm{T}_{\text {reg }}$ cells and invasive breast cancer cells secrete matrix metalloproteinases (MMPs) 

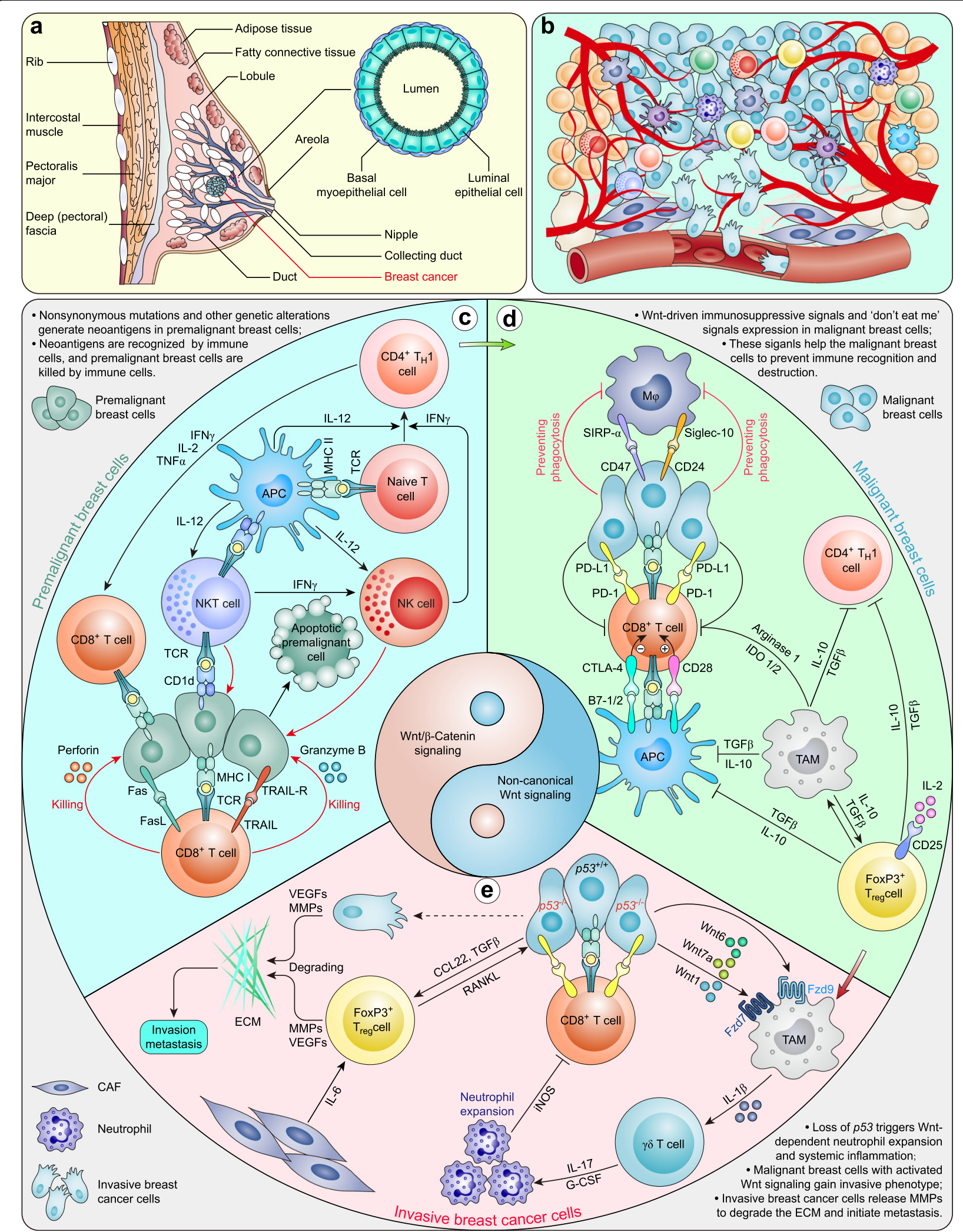

Fig. 5 Wnt signaling in the immune microenvironment of breast cancer. a Schematic representation of the human mammary gland, breast cancer, and an enlarged cross-section of the duct (adapted from [272]). b Tumor microenvironment of breast cancer. $\mathbf{c}$ Wnt signaling in the immune microenvironment of breast cancer 
and vascular endothelial growth factors (VEGFs) to degrade the ECM and promote angiogenesis, resulting in breast cancer metastasis (Fig. 5 e). Of note, MMPs and VEGFs are classic targets of Wnt signaling [324]. Collectively, these findings show that Wnt-driven systemic inflammation and the immunosuppressive niche provide an immune microenvironment for breast cancer metastasis.

\section{Wnt signaling in the EMT-dependent metastasis of breast cancer}

The immune microenvironment is an external factor in breast cancer metastasis, while genetic alteration-driven cell transformation is the internal factor in breast cancer metastasis [325]. Increasing evidence suggests that EMT contributes to the primary cause of breast cancer metastasis, especially for BLBCs [326]. The term EMT refers to a complicated and highly regulated molecular and cellular process by which epithelial cells shed their differentiated characteristics and acquire mesenchymal features [327]. Snai1 (Snail), Snai2 (Slug), Twist1, ZEB1, and ZEB2 (also known as Sip-1 and Zfhx1b) are core EMT transcription factors (EMT-TFs) [328]. These core EMT-TFs are mechanically activated by TGF $\beta$-Smads, Wnt/ $\beta$-Catenin signaling, epidermal growth factor (EGF)/fibroblast growth factor (FGF)-receptor tyrosine kinase (RTK) signaling, Notch signaling, and the MAPK pathway, further initiating EMTassociated changes in gene expression, such as the suppression of E-cadherin and ZO-1 and the activation of $\mathrm{N}$ Cadherin, MMPs, integrins, and fibronectin [329].

The overexpression of core EMT-TFs has been observed in primary invasive breast cancer and is usually associated with a poor prognosis [327, 330-333]. Specifically, Snail [224], Slug [16, 334], Twist1 [15], ZEB1, and ZEB2 [333] are commonly overexpressed in BLBCs. While Snail [322, 331], Slug [321], Twist1 [335], and ZEB1 [336] are direct targets of $\mathrm{Wnt} / \beta$-Catenin signaling in breast cancer, ZEB2 is inclined to be an upstream factor of $\mathrm{Wnt} / \beta$-Catenin signaling [337, 338]. Twist1, ZEB1, and ZEB2 are also induced by the MAPK pathway and may be mediated through TGF $\beta$ and noncanonical Wnt signaling [329] (Fig. 6). Overexpressed EMT-TFs suppress the expression of E-cadherin, leading to the release of $\beta$-Catenin from the cytomembrane into the cytoplasm (Fig. 1). Free $\beta$-Catenin, in turn, promotes the expression of EMT-TFs, thereby forming a positive feedback loop. In addition, Wnt5a/b and Fzd2 drive EMT through a noncanonical Wnt pathway that includes Fyn and Stat3 [22]. The early dissemination and metastasis of Her- $2^{+}$breast cancer are also driven by the noncanonical Wnt (Wnt5a, Wnt5b, and Wnt11)-dependent EMT-like pathway [11]. Wnt-driven EMT-TF expression further regulates the morphogenesis of breast cancer cells [341] (such as the formation of lamellipodia [342]) and directly secretes MMPs, thereby acquiring migratory and invasive properties. Indeed, EMT also contributes to chemoresistance [343], stem cell properties [344], and immunosuppression [345].

\section{Wnt signaling in the inter- and intratumoral heterogeneity of breast cancer}

Extensive molecular and cellular heterogeneity exists in human breast cancer tissues [312, 346] and determines the diversity of pathological features, prognoses, and responses to available therapy [347]. The heterogeneity of breast cancer involves complicated concepts, termed intertumoral heterogeneity (tumors from different patients), mammary epithelial differentiation hierarchy, intertumoral heterogeneity (within a single tumor), and breast cancer stem cells (BCSCs) [348].

The intertumoral heterogeneity of breast cancer can be explained by a mammary epithelial differentiation hierarchy theory by which different mammary epithelial cell subpopulations that reside in mammary ducts provide a repertoire for intertumoral heterogeneity. Two hypothetical models of mammary epithelial differentiation hierarchy have been established based on gene expression profiling, and the difference lies in whether adult quiescent mammary stem cells (MaSCs) exist [349]. Cumulative evidence indicates that adult bipotent or multipotent quiescent MaSCs, such as LGR5 ${ }^{+}$Tspan8high MaSCs [350], may reside within the adult mammary gland [351, 352].

Wnt signaling executes cardinal roles in maintaining the phenotype of MaSCs [349]. Mouse MaSCs are identified by the surface marker $\operatorname{Lin}^{-} \mathrm{CD} 24^{+} \mathrm{CD} 29^{\text {high }}$ subpopulation, which is expanded in MMTV-Wnt1-induced premalignant mammary tissue [353]. On the other hand, human stem-like cells identified by the surface marker $\mathrm{Lin}^{-} \mathrm{CD} 10^{-} \mathrm{CD} 24^{-}$ProCr ${ }^{+} \mathrm{CD} 44^{+}$subpopulation have been identified in both normal human mammary epithelium and breast carcinomas [21]. Notably, both protein $\mathrm{C}$ receptor (ProCr) and CD44 are targets of Wnt/ $\beta$-catenin signaling $[21,354]$. LRG5 is not only a coreceptor (Fig. 1) but also a target of $\mathrm{Wnt} / \beta$-catenin signaling [355]. LRG5 ${ }^{+}$mammary epithelial cells contribute to the reconstitution of an entire mammary gland, suggesting that LRG5 is a potent biomarker of MaSCs [356]. MMP3, as an extracellular regulator of the Wnt signaling pathway, is necessary for the phenotype and activity maintenance of MaSCs [41]. Axin2 is not only a target but also a negative feedback regulator of Wnt signaling (Fig. 1) and is therefore sensitized to Wnt signals. The Wnt-responsive cell population with Axin $2^{+}$is enriched for MaSCs in the adult mammary gland [357, 358]. In addition, the macrophages that receive the Notch pathway ligand Dll1 from MaSCs, together with $\mathrm{Gli}^{+}$stromal cells, govern MaSCs by secreting Wnts and other paracrine factors [359, 360]. These data demonstrate 


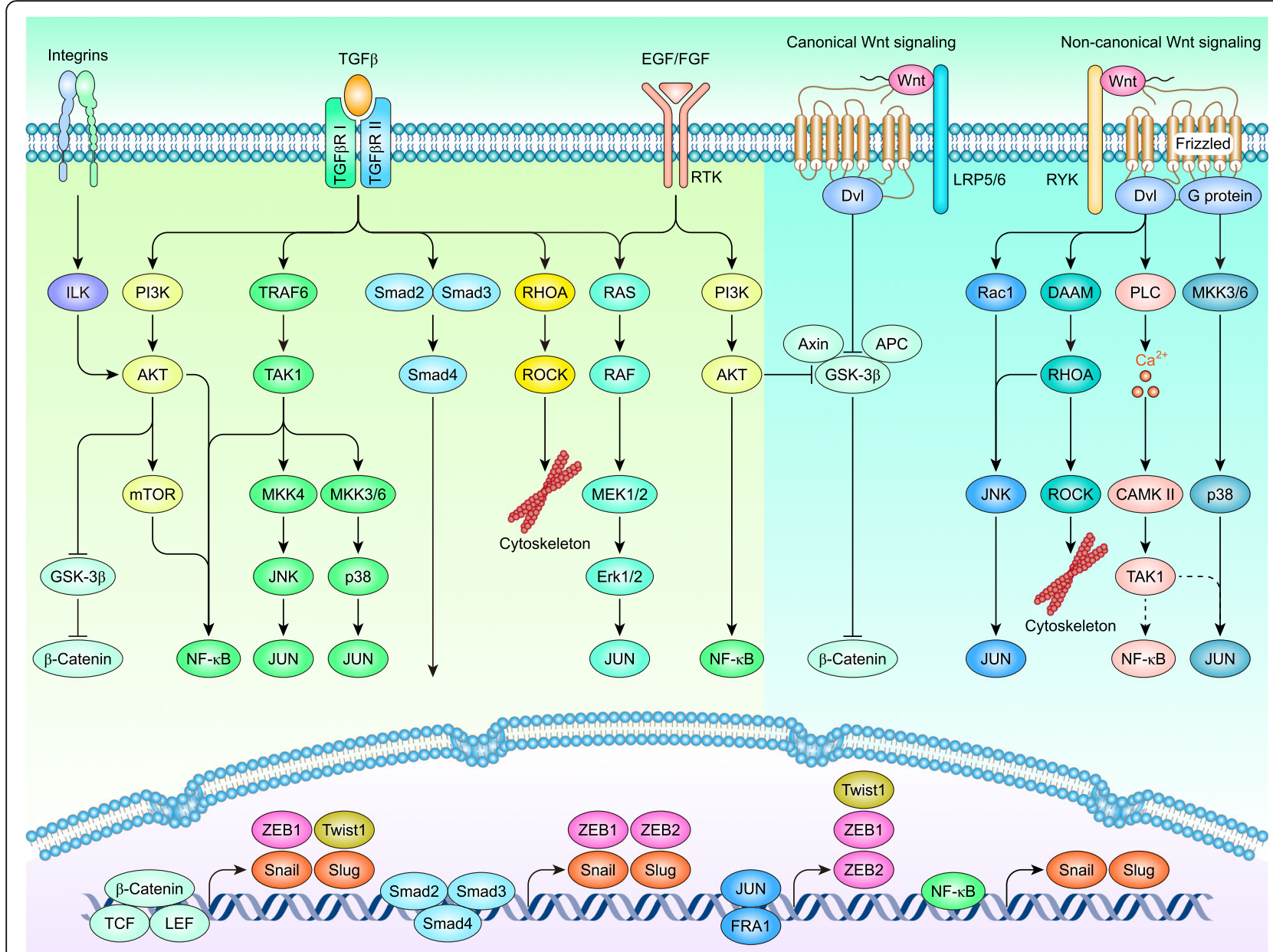

Fig. 6 Wnt signaling in the EMT-dependent metastasis of breast cancer. (adapted from $[329,339,340]$ )

that Wnt signaling is essential for MaSCs to maintain their phenotype and self-renewal.

A comparison of the gene signatures between normal mammary epithelial subpopulations and breast cancer subtypes implied that the claudin-low cancer subtype is remarkably similar to LGR $^{+}$Tspan $8^{\text {high }}$ MaSCs [349, 350]. In contrast, the basal-like cancer subtype shares great similarity to the luminal progenitor subpopulation $[361,362]$. The Her- $2^{+}$, luminal B, and luminal A cancer subtypes reflect different cell subtypes within the luminal lineage and in turn gradually lose differentiation capacity. Therefore, the luminal A subtype is closest to mature luminal cells, while the $\mathrm{Her}-2^{+}$and luminal B subtypes likely originate in cells restricted to the luminal lineage [349]. These findings suggest a hypothesis that various breast cancer subtypes (intertumoral heterogeneity) are derived from different mammary epithelial cell subpopulations [363] (Fig. 7). Although Wnt signaling controls various aspects of mammary gland development and differentiation during both embryogenesis and postnatal life [358], this hypothesis is derived from the conjecture of comparative genomics rather than facts. More sophisticated lineage tracing systems may be required to address this question in the future.

Two models have been proposed to account for the intratumoral heterogeneity of breast cancer. The clonal evolution model explains intratumor heterogeneity as a result of natural selection and uses stochastic mutations as a platform. Advantageous clones differ in time and space within an individual tumor and thereby contribute to the intratumoral heterogeneity of breast cancer [348]. The cancer stem cell model hypothesizes that the intratumoral heterogeneity is derived from common malignant self-renewing cells that can generate the full repertoire of tumor cells (i.e., BCSCs). BCSCs are hypothesized to be breast cancer-initiating cells (BCICs) that undergo a second oncogenic event by which BCSCs gain the ability of sustained propagation, whereas BCICs are hypothesized to be MaSCs that undergo one oncogenic event [364]. BCSCs were initially identified by surface markers as $\mathrm{Lin}^{-} \mathrm{CD} 44^{+} \mathrm{CD} 24^{- \text {low }}$ [365]. Subsequently, an aldehyde dehydrogenase 1 (ALDH1) ${ }^{+}$BCSC population capable of 


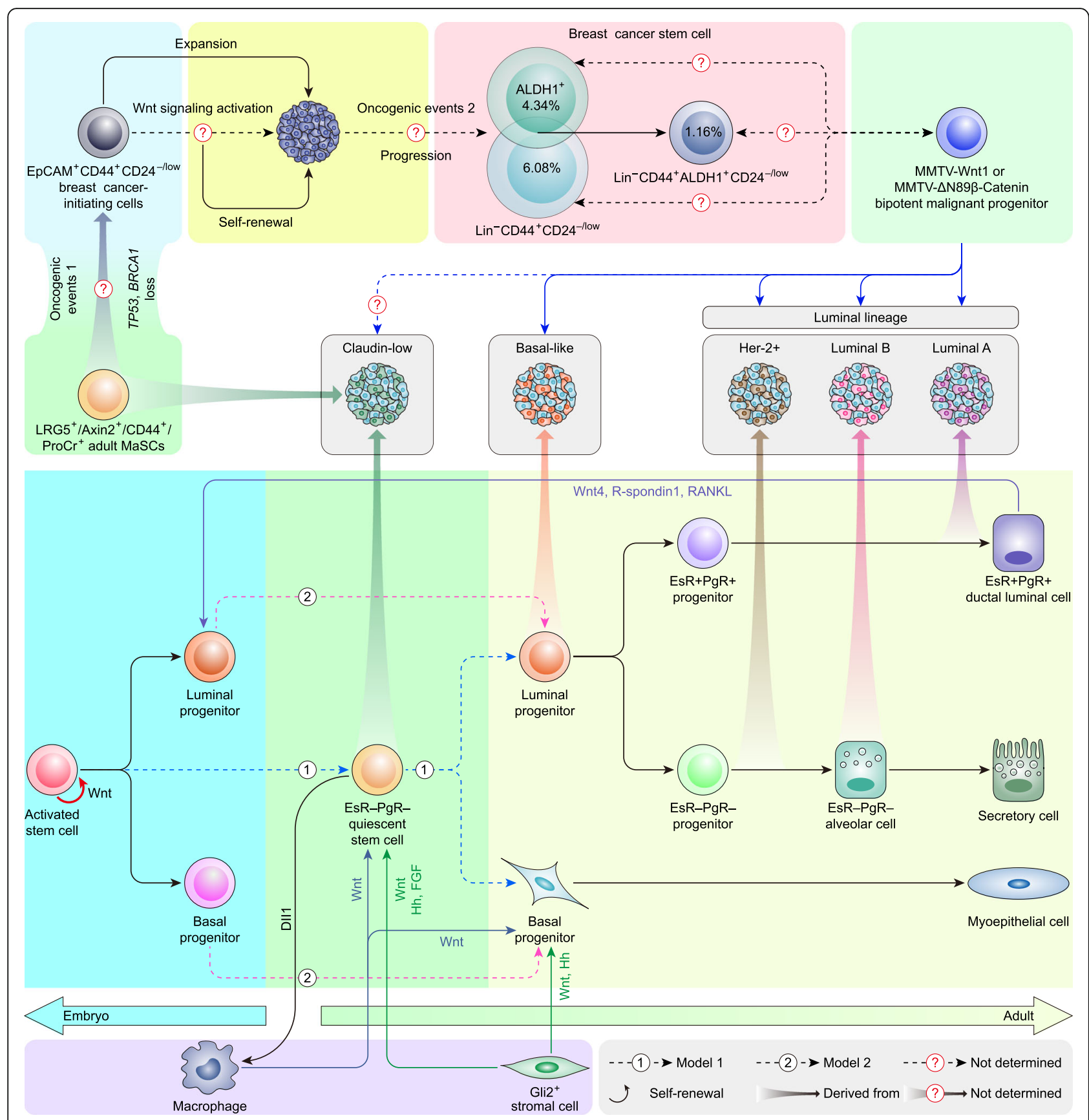

Fig. 7 Wnt signaling in the inter- and intratumoral heterogeneity of breast cancer. (adapted from [349])

self-renewal and of generating tumors that recapitulate the heterogeneity of the parental tumor was identified [366]. Of note, a portion of $\mathrm{Lin}^{-} \mathrm{CD} 44^{+} \mathrm{CD} 24^{-/ \text {low }} \mathrm{BCSCs}$ overlap with $\mathrm{ALDH} 1^{+} \mathrm{BCSCs}$, and $\mathrm{Lin}^{-} \mathrm{CD} 44^{+} \mathrm{CD} 24^{-/ \mathrm{lo}-}$ ${ }^{\mathrm{w}} \mathrm{ALDH}^{+}{ }^{+}$BCSCs display a more tumorigenic feature [366] (Fig. 7).

Wnt signaling is critical not only to the phenotypic maintenance of BCSCs but also to MaSC-BCSC transformation. CD44 is a well-known target of Wnt/ $\beta$-catenin signaling and contributes the 'stemness' properties to BCSCs [21].
The depletion of CD44 effectively prevents aggregation, blocks lung metastasis, and impairs the 'stemness' of circulating breast tumor cells [367]. ProCr is another target of Wnt/ $\beta$-catenin signaling, and $\mathrm{ProCr}^{+} \mathrm{MaSCs}$ represent one of the origins of BCSCs [354]. Intriguingly, $100 \%$ of CD44 $4^{+}$ breast tumor cells are positive for ProCr [21]. Indeed, the expression level of CD44 is also controlled by noncanonical Wnt5a [15] and Wnt5b [16]. As discussed above, ALDH1 ${ }^{+}$ BCSCs represent another important subpopulation of BCSCs [366]. ALDH1 is not a direct target of Wnt/ß- 
catenin signaling; however, its activity is controlled by syndecan-1, a coreceptor of noncanonical Wnt-PCP signaling (Fig. $2 \mathrm{c}$ ), and the BCSC phenotype that is characterized by ALDH1 activity and $\mathrm{CD} 44^{+} \mathrm{CD} 24^{-/ \text {low }}$ is reduced upon Syndecan-1 knockdown [248]. These findings suggest that the phenotypic maintenance of BCSCs is governed jointly by both canonical and noncanonical Wnt signaling.

The constitutive overexpression of Wnt1 in the mammary gland directly gives rise to tumors [5], suggesting that Wht signaling activation is an independent oncogenic event. MMTV-Wnt1- and MMTV- $\triangle$ N893-Catenin-induced tumors contain differentiated cells of both luminal and basal lineages, suggesting that the precursor of Wnt1and $\Delta$ N89 $\beta$-Catenin-induced tumors is a bipotential stem cell $[24,368]$. The loss of Pten accelerates the dysregulation of this subpopulation during tumor initiation [288]. Intriguingly, MMP3, as a regulator of Wnt signaling, maintains the phenotype of MaSCs on one side [41] and promotes mammary carcinogenesis on the other [369]. Additionally, the $\mathrm{Lin}^{-} \mathrm{CD} 24^{+} \mathrm{CD} 29^{\text {high }}$ MaSC subpopulation is expanded in MMTV-Wnt1-induced premalignant mammary tissue [353]. These findings indicate that Wnt signaling is the principal driver in MaSC-BCSC transformation. However, the relationship between Wnt $1 / \Delta \mathrm{N} 89 \beta$-Catenin-induced bipotential stem cells and $\mathrm{Lin}^{-} \mathrm{CD} 44^{+} \mathrm{CD} 24^{-/ \text {low }}$ or $\mathrm{ALDH}^{+}{ }^{+} \mathrm{BCSC}$ remains obscure (Fig. 7).

\section{Wnt signaling in breast cancer drug resistance}

Drug resistance in cancer is considered to be a multifaceted problem involving tumoral heterogeneity, drug efflux/inactivation, survival pathway activation, etc. [370]. The Goldie-Coldman hypothesis explains drug resistance as a result of directed selection and uses heterogeneous tumor cell clones with various mutations as a platform [371, 372]. Drug-resistant clones survive and expand under toxic drug stress; on the other hand, Wnt signaling inactivation causes BCSCs to enter a quiescent state that is insensitive to drugs [352, 373], thereby leading to multidrug resistance. The Wnt signaling-mediated mammary epithelial differentiation hierarchy and the formation and selfrenewal of BCSCs are drivers of the tumoral heterogeneity of breast cancer (Fig. 8 a).

Drug efflux from cancer cells mediated by ATPbinding cassette $(\mathrm{ABC})$ transporters is another vital pathway in the drug resistance of breast cancer. Pglycoprotein (P-gp, also known as MDR1, encoded by $A B C B 1$ ), multidrug resistance protein 1-5 (MRP1-5, encoded by $A B C C 1-5)$, and breast cancer resistance protein (BCRP, encoded by $A B C G 2$ ) are well-defined $A B C$ transporters that are involved in the transport of clinically relevant drugs [375]. PYGO2 is a coactivator in Wnt/ $\beta$-catenin signaling (Fig. 1) that mediates chemoresistance by activating MDR1 expression in breast cancer
[376]. Caveolin 1 is overexpressed and amplified in a subset of basal-like and metaplastic breast carcinomas $[377,378]$ and promotes drug resistance by increasing ABCG2 expression in a Wnt/ $\beta$-catenin signalingdependent manner [379, 380] (Fig. 8 b).

EsR-positive breast cancers account for nearly $80 \%$ of all breast cancer cases [1], and approximately $50 \%$ of mortalities arise from EsR-positive breast tumors [381]. EsR is a ligand-inducible transcription factor that contains a central DNA binding domain, an intrinsically disordered $\mathrm{N}$-terminal activation function 1 (AF1) domain, and a C-terminal ligand-binding domain (LBD) [381]. Tamoxifen was the first clinically approved EsR-targeted drug and competes with $17 \beta$-estradiol (E2) for EsR binding and prevents LBD-mediated coactivator recruitment, thereby impairing the transcriptional activity of EsR [381]. The primary (4-hydroxytamoxifen) and secondary (endoxifen) metabolites of tamoxifen mediated by the cytochrome P450 system are more potent than tamoxifen itself [374]. Cytochrome P450 2D6 (CYP2D6) is undoubtedly the key enzyme for endoxifen generation. One-third of women treated with tamoxifen for 5 years experience recurrence within 15 years, and endocrineresistant disease may account for $25 \%$ of all breast cancers [382]. Inactive CYP2D6 that fails to convert tamoxifen to endoxifen and the lack of $E R \alpha$ expression are primary mechanisms of endocrine resistance [383]. Intriguingly, both canonical and noncanonical Wnt signaling pathways are activated in tamoxifen-resistant breast cancer cells, and Wnt3a increases the resistance of EsR ${ }^{+}$breast cancer cells to tamoxifen treatment [384]. Furthermore, Sox 2 is increased in tamoxifen-resistant breast cancer cells and negatively correlated with ER $\alpha$ expression. Sox 2 also maintains the phenotype of breast cancer stem/progenitor cells by activating Wnt signaling, thereby rendering EsR ${ }^{+}$breast cancer cells insensitive to tamoxifen treatment [14]. Although there is no direct evidence to prove the relationship between Wnt signaling and CYP2D6 activity or tamoxifen metabolism, some studies indicate that such a relationship may exist. Endoxifen levels are 20\% lower during winter months than return to mean levels across seasons and are associated with low vitamin D3 levels; thus, vitamin D3 may maintain endoxifen levels by increasing CYP2D6 activity [385]. Indeed, vitamin D3 can regulate intestinal CYP3A4 expression through the binding of the vitamin $\mathrm{D}$ receptor (VDR)-retinoid $\mathrm{X}$ receptor (RXR) heterodimer to the ER6 motif of the CYP3A4 promoter [386, 387]. On the other hand, vitamin D3 increases tamoxifen sensitivity by inhibiting Wnt/ $\beta$-catenin signaling [388] (Fig. 8 c). Of note, vitamin D3 has been proven to be a potent disruptor of $\beta$-Catenin/TCF [389, 390]. Endoxifen is also a substrate of the efflux transporter MDR1 [391], a target of Wnt signaling, as we discussed above [376]. 


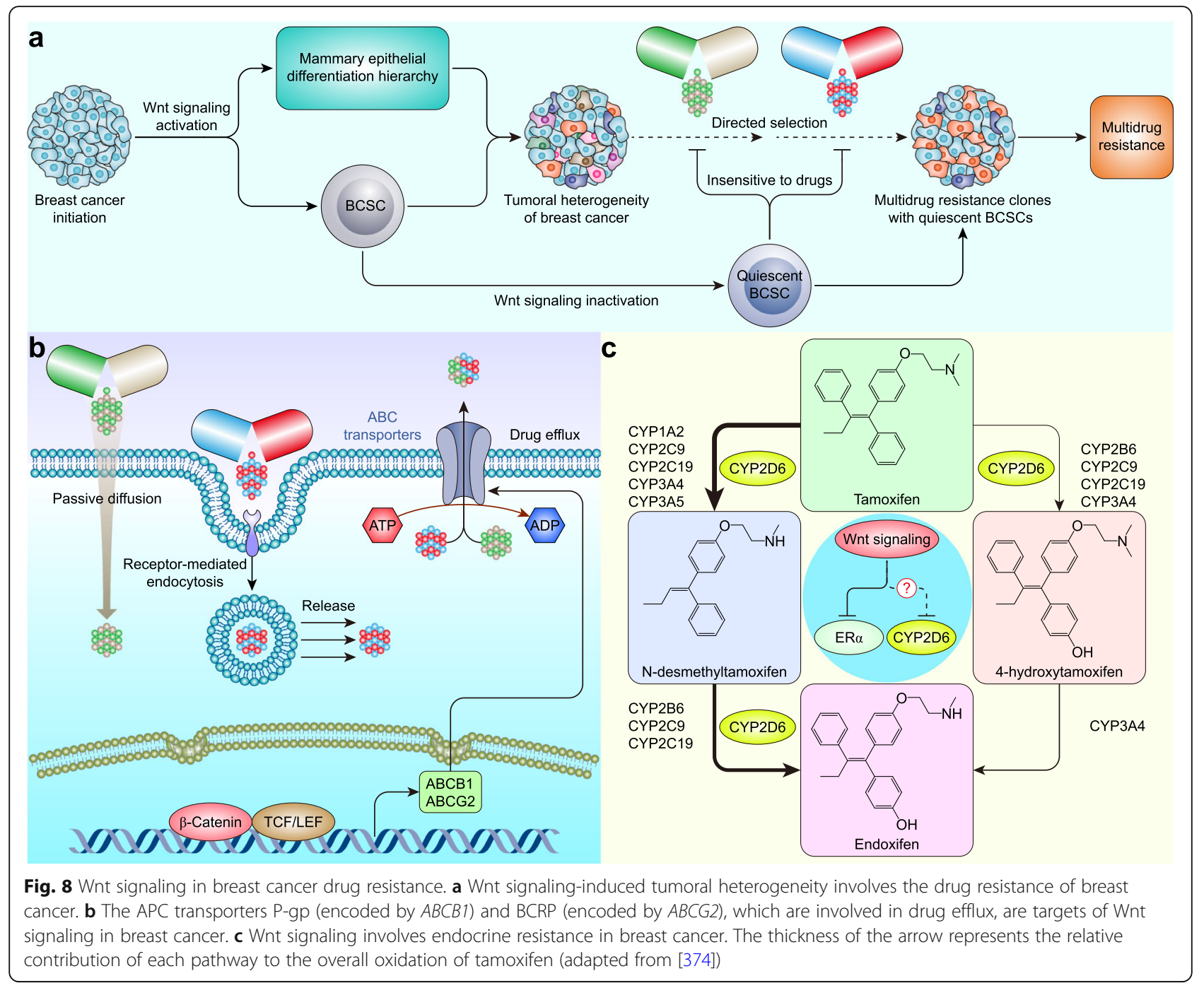

These findings indicate that Wnt signaling is involved in endocrine therapy resistance in breast cancer.

Immunotherapy for breast cancer has attracted wide attention and interest, and immune checkpoint blockade is the most investigated form in more than 290 ongoing clinical trials of breast cancer immunotherapy [392]. Undoubtedly, PD-1/PD-L1 and CTLA-4 are the most attractive targets among immune checkpoint inhibitors [393]. Indeed, more than $40 \%$ of TNBCs are PD-L1 positive, and the anti-PD-L1 monoclonal antibody atezolizumab has been approved by the FDA for advanced or metastatic PD-L1-positive TNBC [394]. Nevertheless, approximately $40 \%$ of PD-L1-positive TNBCs exhibit a poor response to atezolizumab plus nab-paclitaxel treatment. Given the $10.3 \%$ complete response rate in PDL1-positive TNBC, much more effort may be needed [394]. Wnt signaling not only controls the expression of PD-L1 [306] and CTLA-4 [307] but also blocks the tumor-immune cycle at all steps [395]. $\beta$-Catenin/STT3- dependent PD-L1 N-glycosylation stabilizes and upregulates PD-L1, which promotes breast cancer immune evasion [396]. Moreover, MMTV-Wnt1 breast tumors are classified as 'cold tumors', suggesting that Wnt signaling mediates immunotherapy resistance [397]. Thus, targeting Wnt signaling is a potential strategy to enhance the efficacy of cancer immunotherapy (Fig. $5 \mathrm{~d}$ ).

\section{Molecular agents targeting the Wnt signaling pathway in breast cancer}

Hundreds of inhibitors have been developed over the past few decades. These inhibitors are generally focused on targeting Porcupine, Fzds, DVLs, TNKS $1 / 2$, and $\beta$ Catenin/TCF or $\beta$-Catenin/coactivators.

Porcupine inhibitors have recently received great attention because of their broad-spectrum Wnt-targeted and anticancer activity. LGK974, a representative Porcupine inhibitor, is being tested in a phase I clinical trial in patients with TNBC and other Wnt-driven cancers [16, 


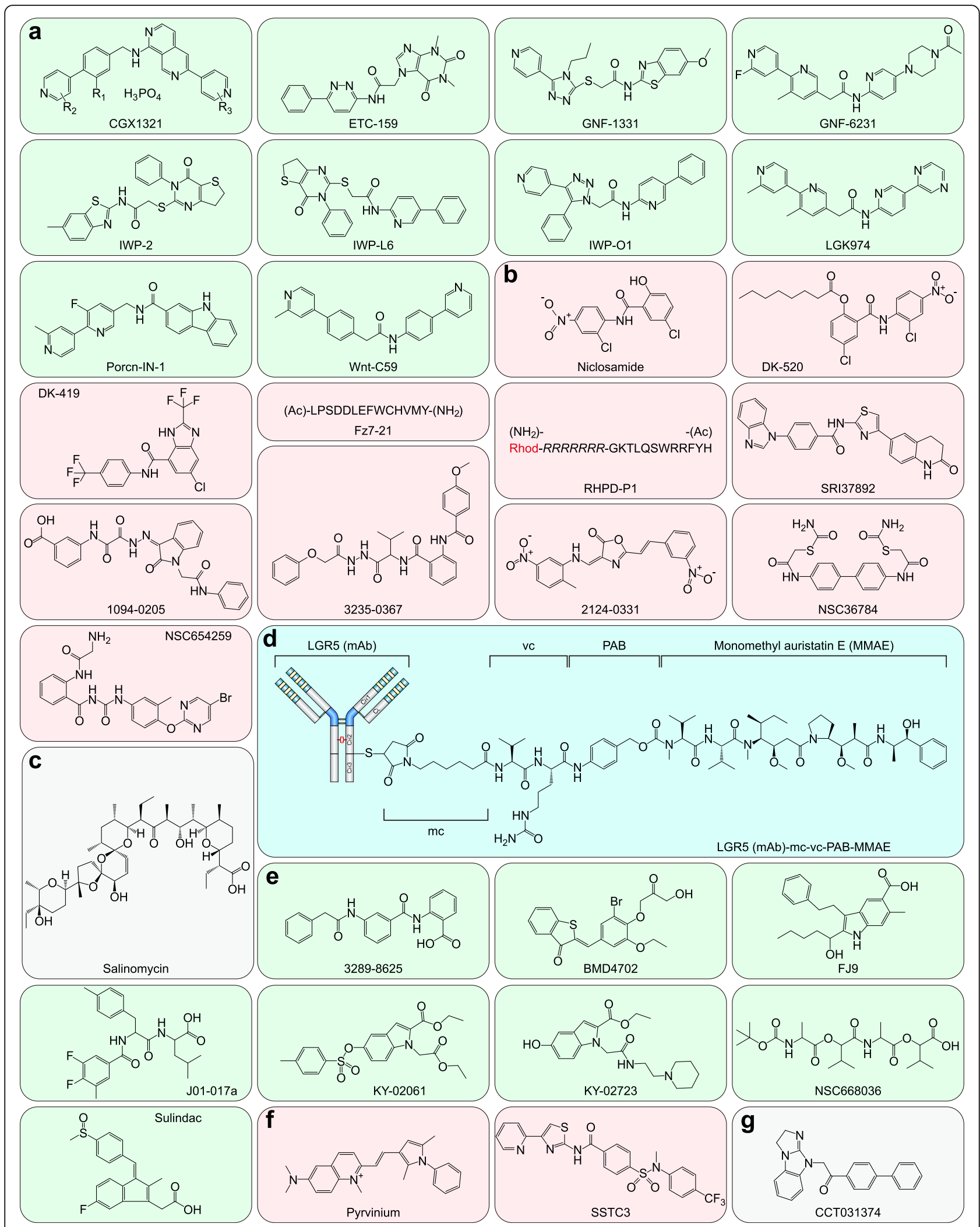

Fig. 9 Selected Wnt signaling inhibitors (Part 1). a Porcupine inhibitors. b Fzd inhibitors. c Wnt/Fzd/LRP inhibitor. d LGR5-specific antibody-drug conjugate. e Dvl inhibitors. $\mathbf{f}$ CK1a agonists. g GSK-3ß agonist 
63, 398]. Of note, GNF-6231, Porcn-IN-1, and Wnt-C59 are LGK974 analogs (Fig. 9 a and Table 4). Perturbation of Wnt-Fzd interactions is another strategy to block Wnt signaling transduction. OMP-54F28 is an Fc fusion protein that contains the extracellular N-terminal cysteine-rich domain (CRD) of Fzd8 and serves as a decoy receptor, competing with Fzd8 for all Wnts [17, $408,409]$. R-spondins are indirect activators of Wnt signaling; OMP-131R10, an anti-R-spondin-3 antibody, has entered a phase I clinical trial for solid tumor treatment (Table 5).

Targeting Fzds is also a mainstream strategy to block Wnt signaling. Niclosamide is an FDA-approved antihelminth. As an inhibitor of Fzd1, it has entered phase I/II clinical trials and could be the most promising Fzd inhibitor [411]. OMP-18R5, an antibody that targets multiple Fzds, binds to 5 of the 10 Fzds and is a potential drug for breast cancer and other solid tumors [414]. In addition, OTSA101-DTPA- ${ }^{111}$ In and OTSA101DTPA- ${ }^{90} \mathrm{Y}$ are humanized chimeric anti-Fzd10 antibodies (named OTSA-101) that are radiolabeled with Indium 111 and Yttrium 90, respectively. OTSA101DTPA- ${ }^{111}$ In is a promising Fzd10-targeted single-photon emission computed tomography (SPECT) imaging agent, while OTSA101-DTPA- $-{ }^{90} \mathrm{Y}$ is a potent Fzd10-targeted agent for metastatic synovial sarcoma radiotherapy [420, 421]. Salinomycin is an FDA-approved supplement in poultry feed and kills BCSCs selectively [424]. It was subsequently proven to block Wnt-induced LRP phosphorylation [422]. LGR5 (mAb)-mc-vc-PAB-MMAE is an LGR5-specific antibody-drug conjugate (ADC). Monomethyl auristatin E (MMAE) is a tubulininhibiting cytotoxic drug that kills LGR5-positive cancer cells selectively [423] (Fig. 9 b-d and Table 5).

Dvls, as the main intracellular effectors of the Wnt/ Fzd/LRP complex, are ideal targets. Quite a few smallmolecule inhibitors have been developed for Dvl inhibition. Sulindac is the most promising Dvl inhibitor among these small-molecule inhibitors. It is an FDAapproved nonsteroidal anti-inflammatory drug that has been shown to have clinically significant anticancer effects. Sulindac is an inhibitor of not only cyclooxygenase $1 / 2(\mathrm{COX} 1 / 2)$ [425] but also Dvl in the PDZ domain [426]. It is hypothesized to suppress tumor growth by blocking Dvl activity rather than prostaglandin synthesis [427, 428] (Fig. 9 e and Table 6).

$\beta$-Catenin is the key to canonical Wnt signaling. The direct inhibition or degradation of $\beta$-Catenin is assuredly an effective strategy. Only two small molecules (MSAB [435] and NRX-252262 [436]) that directly target $\beta$ Catenin have been identified to date. Other small molecules that target $\beta$-Catenin by enhancing the formation of the destruction complex, such as activating CK1 $\alpha$ [437-439], GSK-3 $\beta$ [440], and Axin [441], have also received full attention. Another destruction complexindependent strategy is activating Siah-1-induced $\beta$ Catenin degradation with hexachlorophene [442]. Given the critical function of Axin degradation mediated by TNKS1/2, various small-molecule inhibitors have been developed to inhibit TNKS1/2. 2X-121 (also known as E7449), the most promising TNKS1/2 inhibitor, has entered phase I/II clinical trials for breast cancer and ovarian cancer treatment [443, 444] (Fig. 9 f-g, Fig. 10 a-c and Table 7).

Nuclear $\beta$-Catenin serves as a scaffold for its coactivators to bind rather than as an independent transcription factor. Thus, disrupting the interaction between $\beta$ Catenin and its coactivators is also a potent strategy to block Wnt signaling transduction. $\beta$-Catenin/TCF becomes the primary target for disruption. However, vitamin D3, as a potent $\beta$-Catenin/TCF disruptor [389, 390], has been proven to be invalid for cancer prevention and treatment [460, 461]. Disrupting the interaction between $\beta$-Catenin and BCL9 or CBP is an optional strategy to block the transcription of Wnt target genes. PRI-724, as a $\beta$-Catenin/CBP disruptor, has en-

Table 4 Inhibitors of Porcupine

\begin{tabular}{|c|c|c|c|}
\hline Compound & $\mathrm{IC}_{50}$ & Development stage & Ref. \\
\hline$\overline{C G X 1321}$ & $1.0 \mathrm{nM}$ & $\begin{array}{l}\text { Phase I (NCT03507998): Gastrointestinal tumors; } \\
\text { Phase I (NCT02675946): Solid tumors }\end{array}$ & {$[399,400]$} \\
\hline ETC-159 & $2.9 \mathrm{nM}$ & Phase I (NCT02521844): Advanced solid tumors & {$[401]$} \\
\hline LGK974 & $0.1 \mathrm{nM}$ & Phase I (NCT01351103): TNBC and other cancers & {$[16,63,398]$} \\
\hline GNF-1331 & $12 \mathrm{nM}$ & Preclinical & {$[402]$} \\
\hline GNF-6231 & $0.8 \mathrm{nM}$ & Preclinical & {$[402]$} \\
\hline IWP2 & $27 \mathrm{nM}$ & Preclinical & {$[384,403,404]$} \\
\hline IWP-L6 & $0.5 \mathrm{nM}$ & Preclinical & {$[405]$} \\
\hline IWP-O1 & 80 pM & Preclinical & {$[406]$} \\
\hline Porcn-IN-1 & $0.5 \pm 0.2 \mathrm{nM}$ & - & {$[407]$} \\
\hline Wnt-C59 & $74 \mathrm{pM}$ & Preclinical & [398] \\
\hline
\end{tabular}


Table $\mathbf{5}$ Inhibitors of Fzds and related factors

\begin{tabular}{|c|c|c|c|c|}
\hline Compound & Target & $\mathrm{IC}_{50}$ & Development stage & Ref. \\
\hline $\begin{array}{l}\text { OMP-54F28 } \\
\text { (Fzd8-Fc fusion) }\end{array}$ & Wnts & ND & $\begin{array}{l}\text { Phase I (NCT02069145): Hepatocellular cancer; } \\
\text { Phase I (NCT02092363): Ovarian cancer; } \\
\text { Phase I (NCT02050178): Pancreatic cancer; } \\
\text { Phase I (NCT01608867): Solid tumors }\end{array}$ & {$[408]$} \\
\hline OMP-131R10 (mAb) & R-spondin3 & ND & Phase I (NCT02482441): Solid tumors & [410] \\
\hline Niclosamide & Fzd1 & $0.5 \pm 0.05 \mu \mathrm{M}$ & $\begin{array}{l}\text { FDA-approved antihelminth; } \\
\text { Phase I (NCT03123978): Prostate cancer; } \\
\text { Phase II (NCT02519582): Colorectal cancer; } \\
\text { Phase II (NCT02807805): Prostate cancer }\end{array}$ & [411] \\
\hline DK-520 & Fzd1 & $0.23 \pm 0.06 \mu \mathrm{M}$ & Preclinical & [412] \\
\hline DK-419 & Fzd1 & $0.19 \pm 0.08 \mu \mathrm{M}$ & Preclinical & [413] \\
\hline OMP-18R5 (mAb) & Fzd1/2/5/7/8 & ND & $\begin{array}{l}\text { Phase I (NCT01345201): Solid tumors; } \\
\text { Phase I (NCT02005315): Pancreatic cancer; } \\
\text { Phase I (NCT01957007): NSCLC; } \\
\text { Phase I (NCT01973309): Breast cancer }\end{array}$ & [414] \\
\hline $\operatorname{lgG}-2919$ (mAb) & Fzd5/8 & ND & Preclinical & {$[415]$} \\
\hline Fz7-21 & Fzd7 & $50-100 \mathrm{nM}$ & Preclinical & [416] \\
\hline RHPD-P1 & & $7-40 \mu \mathrm{M}$ & Preclinical & [417] \\
\hline SRI37892 & & $0.66 \mu \mathrm{M}$ & Preclinical & [418] \\
\hline 1094-0205 & Fzd8 & $5.0 \pm 1.1 \mu \mathrm{M}$ & Preclinical & [419] \\
\hline 2124-0331 & & $10.4 \pm 2.0 \mu \mathrm{M}$ & Preclinical & [419] \\
\hline $3235-0367$ & & $7.1 \pm 1.4 \mu \mathrm{M}$ & Preclinical & [419] \\
\hline NSC36784 & & $6.5 \pm 0.9 \mu \mathrm{M}$ & Preclinical & [419] \\
\hline NSC654259 & & $5.7 \pm 1.2 \mu \mathrm{M}$ & Preclinical & [419] \\
\hline OTSA101-DTPA- ${ }^{111}$ In; OTSA101-DTPA-90 Y & Fzd10 & ND & Phase I (NCT04176016): Synovial sarcoma & {$[420,421]$} \\
\hline Salinomycin & Wnt/Fzd/LRP & $163 \mathrm{nM}$ & Preclinical & [422] \\
\hline LGR5 (mAb)-mc-vc-PAB-MMAE & LGR5 & ND & Preclinical & [423] \\
\hline
\end{tabular}

ND not determined

Table 6 Inhibitors of Dvls

\begin{tabular}{llll}
\hline Compound & IC $_{\mathbf{5 0}}$ & Development stage & Ref. \\
\hline $3289-8625$ & $12.5 \mu \mathrm{M}$ & Preclinical & {$[429]$} \\
BMD4702 & $\mathrm{ND}$ & Preclinical & {$[430]$} \\
FJ9 & $\mathrm{ND}$ & Preclinical & {$[431]$} \\
J01-017a & $1.5 \pm 0.2 \mu \mathrm{M}$ & Preclinical & {$[432]$} \\
KY-02061 & $24 \mu \mathrm{M}$ & Preclinical & {$[433]$} \\
KY-02327 & $3.1 \mu \mathrm{M}$ & Preclinical & {$[433]$} \\
NSC668036 & $\mathrm{ND}$ & Preclinical & {$[434]$} \\
Sulindac & $\mathrm{ND}$ & FDA-approved nonsteroidal & {$[426]$} \\
& & anti-inflammatory drug; & \\
& & Phase I (NCT00245024): & \\
& & Breast cancer; & \\
& & Phase II (NCT00039520): & \\
& & Breast cancer; & \\
& & Colorectal neoplasms & \\
\end{tabular}

tered a phase I clinical trial for advanced solid tumor treatment [462]. Transducin $\beta$-like protein 1 (TBL1)TBL1-related protein (TBLR1) and $\beta$-Catenin recruit each other, displacing the corepressors TLE and HDAC1 and resulting in the stimulation of Wnt target gene transcription [463]. BC2059 is a $\beta$-Catenin/ TBL1 disruptor and has entered a phase I clinical trial for desmoid tumor treatment [464]. Intriguingly, apicularen $\mathrm{A}$ and bafilomycin $\mathrm{A} 1$, as vacuolar $\mathrm{H}^{+}$-adenosine triphosphatase (V-ATPase) inhibitors, effectively inhibit Wnt signaling [465]. In addition, although the direct targets of KY02111 [466] and SM04690 remain unknown, SM04690 has entered a phase II clinical trial for knee osteoarthritis treatment [467] (Fig. $10 \mathrm{~d}-\mathrm{i}$ and Table 8).

\section{Challenges and opportunities}

Wnt signaling activation in colorectal cancer is induced mainly by $A P C(73 \%)$ and CTNNB1 (5\%) mutations [217], suggesting that canonical $\mathrm{Wnt} / \mathrm{\beta}$-Catenin signaling is the leading form of Wnt signaling in colorectal cancer. By 


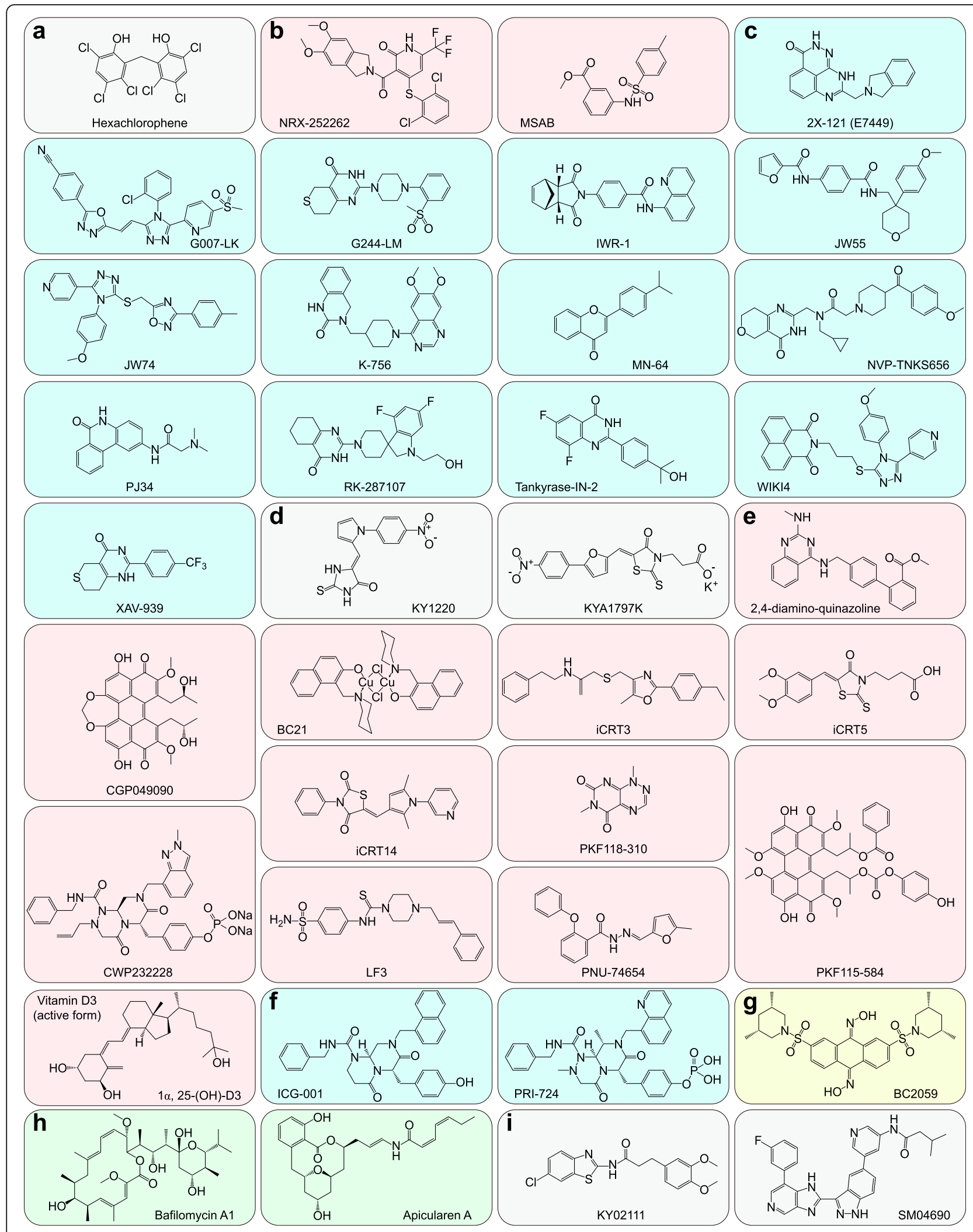

Fig. 10 Selected Wnt signaling inhibitors (Part 2). a Siah-1 agonist. b $\beta$-Catenin destabilizers. c TNKS1/2 inhibitors. d Axin stabilizers. e $\beta$ - Catenin/ TCF disruptors. $\mathbf{f} \beta$-Catenin/CBP disruptors. $\mathbf{g} \beta$-Catenin/TBL1 disruptor. $\mathbf{h}$ V-ATPase inhibitors. i Wnt signaling inhibitors with an unknown target 
Table 7 Small molecules that degrade $\beta$-Catenin at the cytoplasmic level

\begin{tabular}{|c|c|c|c|c|}
\hline Compound & Target & $\mathrm{IC}_{50} / \mathrm{EC}_{50}$ & Development stage & Ref. \\
\hline Pyrvinium & CK1a & $10 \mathrm{nM}$ & FDA-approved antihelminth & {$[437]$} \\
\hline SSTC3 & & $30 \mathrm{nM}$ & Preclinical & [438] \\
\hline ССТ031374 & GSK-3ß & $6.1 \mu \mathrm{M}$ & Preclinical & [440] \\
\hline Hexachlorophene & Siah-1 & $7.03 \mu \mathrm{M}$ & Preclinical & {$[442]$} \\
\hline MSAB & $\beta$-Catenin & $0.583 \mu \mathrm{M}$ & Preclinical & [435] \\
\hline NRX-252262 & & $3.8 \pm 0.2 \mathrm{nM}$ & Preclinical & [436] \\
\hline $2 X-121(E 7449)$ & TNKS1/2 & $50 \mathrm{nM}$ & $\begin{array}{l}\text { Phase II (NCT03562832): Breast cancer; } \\
\text { Phase II (NCT03878849): Ovarian cancer; } \\
\text { Phase I/II (NCT01618136): } \\
\text { TNBC and other cancers; }\end{array}$ & {$[443,444]$} \\
\hline G007-LK & & $0.08 \mu \mathrm{M}$ & Preclinical & {$[445,446]$} \\
\hline G244-LM & & $0.11 \mu \mathrm{M}$ & Preclinical & [445] \\
\hline IWR-1 & & $0.18 \mu \mathrm{M}$ & Preclinical & {$[403,447]$} \\
\hline JW55 & & $470 \mathrm{nM}$ & Preclinical & [448] \\
\hline JW74 & & $420 \mathrm{nM}$ & Preclinical & [449] \\
\hline$K-756$ & & $\begin{array}{l}31 \mathrm{nM} \text { (TNKS1), } \\
36 \mathrm{nM} \text { (TNKS2) }\end{array}$ & Preclinical & [450] \\
\hline MN-64 & & $\begin{array}{l}6 \mathrm{nM}(\text { (TNKS1), } \\
72 \mathrm{nM}(\text { TNKS2) }\end{array}$ & Preclinical & {$[451]$} \\
\hline NVP-TNKS656 & & $6 \mathrm{nM}(\mathrm{TNKS} 2)$ & Preclinical & {$[452]$} \\
\hline PJ34 & & $1 \mu \mathrm{M}(\mathrm{TNKS} 1)$ & Preclinical & [453] \\
\hline RK-287107 & & $\begin{array}{l}14.3 \mathrm{nM} \text { (TNKS1), } \\
10.6 \mathrm{nM}(\mathrm{TNKS2})\end{array}$ & Preclinical & {$[454]$} \\
\hline Tankyrase-IN-2 & & $\begin{array}{l}10 \mathrm{nM} \text { (TNKS1), } \\
7 \mathrm{nM} \text { (TNKS2) }\end{array}$ & Preclinical & [455] \\
\hline WIKI4 & & 26 nM (TNKS2) & Preclinical & {$[456,457]$} \\
\hline XAV939 & & $\begin{array}{l}5 \mathrm{nM} \text { (TNKS1), } \\
2 \mathrm{nM} \text { (TNKS2) }\end{array}$ & Preclinical & {$[133,451,458,459]$} \\
\hline KY1220 & Axin & $2.1 \mu \mathrm{M}$ & Preclinical & [441] \\
\hline KYA1797K & & $0.75 \mu \mathrm{M}$ & Preclinical & [441] \\
\hline
\end{tabular}

contrast, Wnt signaling activation in breast cancer is more complicated and often involves dual effects of canonical and noncanonical Wnt signaling [22, 189, 479]. Although extensive research has been carried out, it is still unclear whether Wnt signaling can be druggable successfully for the therapeutic purposes of breast cancer.

The safety and effectiveness of Wnt signaling-targeted drugs is the most concerning issue that we have to face. Abrogation of the aberrant 'dark side' of Wnt signaling in breast cancer without interfering with its crucial role in tissue homeostasis and repair is undoubtedly the most desirable clinical outcome [17]. However, the majority of available Wnt inhibitors (such as LGK974) are broad spectrum, and it is challenging to achieve balance by controlling the dosage or appropriate time of drug administration. In addition, the effectiveness of Wnt signaling-targeted drugs needs to be further confirmed in clinical trials. Of note, very few inhibitors of noncanonical Wnt signaling have been identified or developed. Extensive crosstalk between noncanonical Wnt signaling and many other signaling pathways exists, making it difficult to specifically target Wnt signaling. ROCK, as a critical component of Wnt-PCP signaling (Fig. 2c), can be inhibited by the small molecule fasudil, thereby blocking Wnt-PCP signaling [480].

Furthermore, the mechanism of balance between canonical and noncanonical Wnt signaling should be addressed. For example, Wnt5a antagonizes canonical Wnt/ $\beta$-Catenin signaling and exhibits tumor-suppressive activity in some circumstances [221, 481-483], but other studies have reported that Wnt5a controls both canonical and noncanonical Wnt signaling [15, 16, 484]. Nusse et al. explained that Wnt5a activates or inhibits $\beta$-Catenin-TCF signaling depending on the receptor context [485]. However, the switch and balance between canonical and noncanonical Wnt signaling may involve 
Table 8 -Catenin inhibitors in cancers

\begin{tabular}{|c|c|c|c|c|}
\hline Compound & Target & $\mathrm{IC}_{50} / \mathrm{EC}_{50}$ & Development stage & Ref. \\
\hline 2,4-diamino-quinazoline & \multirow{12}{*}{$\begin{array}{l}\beta \text {-Catenin/ } \\
\text { TCF }\end{array}$} & $0.6 \mu \mathrm{M}$ & Preclinical & {$[468]$} \\
\hline $\mathrm{BC} 21$ & & $15 \mu \mathrm{M}$ & Preclinical & [469] \\
\hline CGP049090 & & $8.7 \mu \mathrm{M}$ & Preclinical & {$[470,471]$} \\
\hline CWP232228 & & $0.8 \sim 2 \mu \mathrm{M}$ & Preclinical & {$[472]$} \\
\hline iCRT3 & & $8.2 \mathrm{nM}$ & Preclinical & {$[473]$} \\
\hline iCRT5 & & $18.7 \mathrm{nM}$ & Preclinical & {$[473]$} \\
\hline iCRT14 & & $40.3 \mathrm{nM}$ & Preclinical & [473] \\
\hline LF3 & & $1.65 \mu \mathrm{M}$ & Preclinical & {$[474]$} \\
\hline PKF115-584 & & $3.2 \mu \mathrm{M}$ & Preclinical & {$[470,471]$} \\
\hline PKF118-310 & & $0.8 \mu \mathrm{M}$ & Preclinical & {$[470,471]$} \\
\hline PNU-74654 & & ND & Preclinical & {$[475]$} \\
\hline Vitamin D3 & & ND & $\begin{array}{l}\text { Phase II (NCT01948128): Breast cancer; } \\
\text { Phase III (NCT01169259): Cancer and cardiovascular disease; } \\
\text { Phase III (NCT02786875): Breast cancer }\end{array}$ & {$[389,390]$} \\
\hline SAH-BCL9 & $\begin{array}{l}\beta \text {-Catenin/ } \\
\text { BCL9 }\end{array}$ & ND & Preclinical & {$[476]$} \\
\hline ICG-001 & \multirow{2}{*}{$\begin{array}{l}\beta \text {-Catenin/ } \\
\text { CBP }\end{array}$} & $3.0 \mu \mathrm{M}$ & Preclinical & {$[477]$} \\
\hline PRI-724 & & ND & Phase I (NCT01302405): Advanced solid tumors & [462] \\
\hline BC2059 & $\begin{array}{l}\beta \text {-Catenin/ } \\
\text { TBL1 }\end{array}$ & ND & Phase I (NCT03459469): Desmoid tumor & [464] \\
\hline Apicularen A & \multirow[t]{2}{*}{ V-ATPase } & $20 \mathrm{nM}$ & Preclinical & {$[465,478]$} \\
\hline Bafilomycin A1 & & $0.44 \mathrm{nM}$ & Preclinical & {$[465]$} \\
\hline KY02111 & \multirow[t]{2}{*}{ Unknown } & ND & Preclinical & {$[466]$} \\
\hline SM04690 & & $19.5 \mathrm{nM}$ & Phase II (NCT03706521): Knee osteoarthritis & {$[467]$} \\
\hline
\end{tabular}

more profound mechanisms. We propose a bipolar seesaw model to illustrate this ebb and flow: various Wnt ligands and their receptors form a unique combination, and the activation of canonical or noncanonical Wnt signaling depends on this unique combination.
Fzds-Dvls complex-guided downstream kinase cascades differ in canonical and noncanonical Wnt signaling. The switch mechanism may exist not only for the Wnts-Fzds complex but also for downstream kinase cascades (Fig. 11).
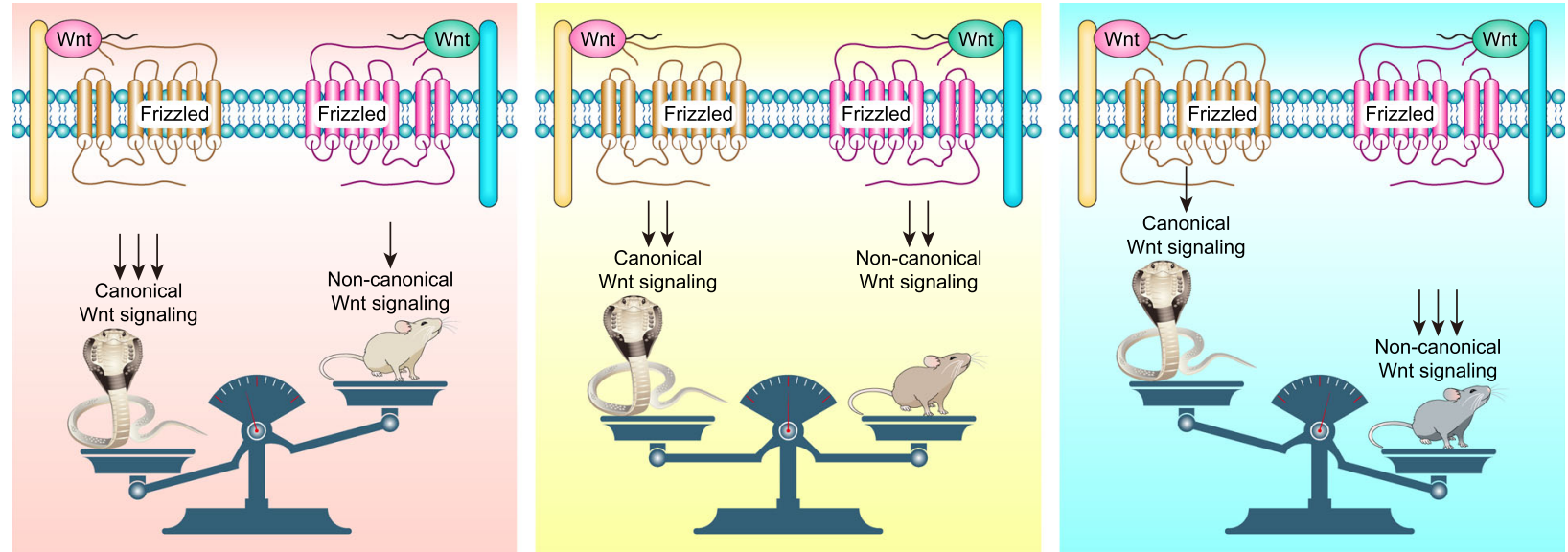

Fig. 11 The bipolar seesaw model between canonical and noncanonical Wnt signaling. (some compositional elements of this figure were obtained from https://www.16pic.com and reference [486]) 
Despite the potential safety and effectiveness concerns regarding the therapeutic targeting of Wnt signaling in breast cancer, constantly emerging novel inhibitors and ongoing clinical trials may ameliorate these issues. Additionally, the application of small-molecule libraries such as Pfizer compounds and molecular docking algorithms based on structural information may accelerate this process. The decryption of underlying mechanisms, including the molecular subtype, tumor stage, and microenvironment context-dependent Wnt signaling activation, as well as the switch and balance between canonical or noncanonical Wnt signaling, is undoubtedly the rationale to ameliorate the safety and effectiveness of Wnt-targeted therapy, especially for breast cancer and other Wnt-driven cancers.

\section{Conclusions}

Accumulating evidence corroborates that the aberrant activation of Wnt signaling exists from breast tumor initiation to distant metastasis. An increasing number of Wnt-targeted small molecules and biologics have entered clinical trials for breast cancer treatment, suggesting that Wnt signaling is an attractive target. The identification of accurate targets and the development of safe and effective drugs are rationales for subsequent clinical trials to determine the appropriate dosage and time of drug administration. Regarding the evolution of Wnt inhibitors, monoclonal antibodies and ADCs will be the mainstream drugs in the future, which is in line with the trend of precision medicine and personalized treatment. Given the unique roles of the noncanonical Wnt pathway in breast cancer, more specific inhibitors should be developed in the future.

Although numerous studies have verified that both canonical and noncanonical Wnt signaling pathways are involved in the progression of breast cancer, there are still no available Wnt-targeted inhibitors for breast cancer treatment in a variety of clinical contexts. Efforts to seek suitable means to regulate Wnt signaling in breast cancer and other Wnt-driven cancers are still ongoing, but emerging discoveries suggest that Wnt-targeted therapy will translate soon into real therapies [90].

\footnotetext{
Abbreviations

7-TM: 7-Transmembrane; ABC transporters: ATP-binding cassette transporters; ADC: Antibody-drug conjugate; AF1: Activation function 1; ALDH1: Aldehyde dehydrogenase 1; AP1: Activator protein 1; APC: Adenomatous polyposis coli; APCs: Antigen-presenting cells; ATF2: Activating transcription factor 2; BCICs: Breast cancer-initiating cells; BCL9: B cell lymphoma 9; BCRP: Breast cancer resistance protein; BCSCs: Breast cancer stem cells; BLBC: Basal-like breast cancer; BL-1: Basal-like 1; BL-2: Basal-like 2; CAFs: Cancer-associated fibroblasts; CAMK II: Calcium calmodulin mediated kinase II; CapZIP: CapZinteracting protein; CBP: CREB-binding protein; CBY: Chibby; Cdc42: Celldivision cycle 42; Celsr1: Cadherin EGF LAG seven-pass G-type receptor 1; CGMP: Cyclic guanosine monophosphate; CK1a: Casein kinase 1a; COX1/ 2: Cyclooxygenase 1/2; CRD: Cysteine-rich domain; CTBP: C-terminal binding protein; CTLA-4: Cytotoxic T lymphocyte antigen 4; CYP2D6: Cytochrome
}

P450 2D6; DAAM: Dishevelled-associated activator of morphogenesis; DAG: Diacylglycerol; DCIS: Ductal carcinoma in situ; Dkks: Dickkopf proteins; DIA1: Diaphanous 1; Dvl: Dishevelled; ECM: Extracellular matrix; EGF: Epidermal growth factor; EMT: Epithelial-mesenchymal transition; EMTTFs: EMT transcription factors; ER: Endoplasmic reticulum; EsR: Estrogen receptor; FasL: Fas ligand; FDA: Food and Drug Administration; FGF: Fibroblast growth factor; FoxP3: Forkhead box protein P3: Fzds: Frizzleds; G-CSF: Granulocyte colony-stimulating factor; GRG: Groucho;

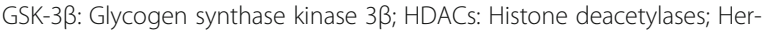
2: Human epidermal growth factor receptor 2; LBD: Ligand-binding domain; ICAT: Inhibitor of $\beta$-Catenin and TCF; IDC-NST: Invasive ductal carcinoma nospecial-type; IDO: Indoleamine 2,3-dioxygenase; IFN- $\gamma$ : Interferon $\gamma_{\text {; }}$ IGFBP4: Insulin-like growth factor-binding protein 4; IL: Interleukin; ILC: Invasive lobular carcinoma; IM: Immunomodulatory; iNOS: Inducible nitric oxide synthase; Ins $\mathrm{P}_{3}$ : Inositol-1, 4, 5-trisphosphate; InsP $\mathrm{P}_{3} \mathrm{Rs}$ : Inositol-1,4,5trisphosphate receptors; Intu: Inturned; Invs: Inversin; JNK: Jun N-terminal kinase; LAR: Luminal androgen receptor; LCIS: Lobular carcinoma in situ; LEF1: Lymphoid Enhancer Factor 1; LGR5: Leucine-rich repeat-containing G protein-coupled receptor 5; LRPs: Low-density lipoprotein receptor-related proteins; M: Mesenchymal; MaSCs: Mammary stem cells; MHC I: Major histocompatibility complex class I; MKK3/6: Mitogen-activated protein kinase 3/6; MMAE: Monomethyl auristatin E; MMPs: Matrix metalloproteinases; MMTV: Mouse mammary tumor virus; MRLC: Mitogen-activated protein kinase; MRP1-5: Multidrug resistance protein 1-5; MSL: Mesenchymal stemlike; MUSK: Muscle skeletal receptor Tyr kinase; NFAT: Nuclear factor of activated T cells; NLK: Nemo-like kinase; PCP: Planar cell polarity; PDE6: Phosphodiesterase 6; PD-L1: Programmed death-ligand 1; PKG: Protein kinase G; P-gp: P-glycoprotein; PgR: Progesterone receptor; PKC: Protein kinase C; PLC: Phospholipase C; PP2A: Protein phosphatase 2A; ProCr: Protein C receptor; Ptdlns $P_{2}$ : Phosphatidylinositol-4,5-bisphosphate; PTK7: Protein Tyr kinase 7; PYGO: Pygopus; RANK: Receptor activator of nuclear factor-kB; RANK $\mathrm{L}$ : Receptor activator of nuclear factor-kB ligand; RHOA: RAS homologue gene-family member A; ROCK: RHO-associated coiled-coil-containing protein kinase; ROR1/2: Receptor Tyr kinase-like orphan receptor 1/2; RTKs: Receptor tyrosine kinases; RXR: Retinoid X receptor; RYK: Receptor-like tyrosine kinase; SCF ${ }^{\beta-T r C P}:$ Skp1, Cullin1 and F-box protein $\beta$-TrCP; SERCAs: Sarcoplasmic/ER $\mathrm{Ca}^{2+}$ ATPases; sFRPs: Secreted Frizzled-related proteins; SOCE: Store-operated $\mathrm{Ca}^{2+}$ entry; SPECT: Single-photon emission computed tomography; STIM1/ 2: Stromal interaction molecule 1/2; TAK1: TGF $\beta$-activated protein kinase 1; TAMs: Tumor-associated macrophages; TBL1: Transducin $\beta$-like protein 1; TBLR1: TBL1-related protein; TCF: T cell factor; TLE: Transducin-like enhancer; TNBC: Triple-negative breast cancer; TNKS1/2: Tankyrase 1/2; TNF-a: Tumor necrosis factor a; TRAIL: TNF-related apoptosis-inducing ligand; $V$ -

ATPase: Vacuolar $\mathrm{H}^{+}$-adenosine triphosphatase; Vangl2: Vang-like 2; VDR: Vitamin D receptor; VEGFs: Vascular endothelial growth factors; WIF1: Wnt inhibitory factor 1; Wnts: Wnt proteins; WTX: Wilms tumor gene on $X$ chromosome

\section{Acknowledgments}

Not applicable.

\section{Authors' contributions}

SJ drafted the manuscript with $X X, M Z$, and FX; SJ conceived the idea, constructed the figures, and revised the manuscript. All authors read and approved the final manuscript.

\section{Funding}

This study was supported by the Zhejiang Provincial Natural Science Foundation of China (LGF18H180009 to XX, LY21C070002 to SJ, LY20H160035 to MZ \& LY19H280009 to FX); the General Program of National Natural Science Foundation of China (61976075 to XX); and the Zhejiang Provincial Science and Technology Plan of Traditional Chinese Medicine (C2019ZB079 to FX).

\section{Availability of data and materials}

Not applicable.

Ethics approval and consent to participate Not applicable. 


\section{Consent for publication}

Not applicable.

\section{Competing interests}

The authors have declared that no competing interests exist.

\section{Author details}

${ }^{1}$ School of Medical Imaging, Hangzhou Medical College, Hangzhou 310053, Zhejiang, China. ${ }^{2}$ Department of Orthopedic Surgery, Second Affiliated Hospital, School of Medicine, Zhejiang University, Hangzhou 310009, Zhejiang, China.

Received: 3 August 2020 Accepted: 22 October 2020

Published online: 24 November 2020

\section{References}

1. DeSantis CE, Ma J, Gaudet MM, Newman LA, Miller KD, Goding Sauer A, Jemal A, Siegel RL. Breast cancer statistics, 2019. CA Cancer J Clin. 2019; 69(6):438-51.

2. Kos K, Wellenstein M, Vrijland K, Hau CS, De Visser K. PO-386 dissecting the role of regulatory $T$ cells in metastatic breast cancer. In: Tumour Immunology. 2018:A378.373-A379.

3. Wellenstein MD, Coffelt SB, Duits DEM, van Miltenburg MH, Slagter M, de Rink I, Henneman L, Kas SM, Prekovic S, Hau CS, et al. Loss of p53 triggers WNT-dependent systemic inflammation to drive breast cancer metastasis. Nature. 2019:572(7770):538-42.

4. Komiya Y, Habas R. Wnt signal transduction pathways. Organogenesis. 2008, 4(2):68-75.

5. Nusse R, Varmus HE. Many tumors induced by the mouse mammary tumor virus contain a provirus integrated in the same region of the host genome. Cell. 1982;31(1):99-109.

6. van Ooyen A, Nusse R. Structure and nucleotide sequence of the putative mammary oncogene int-1; proviral insertions leave the protein-encoding domain intact. Cell. 1984;39(1):233-40.

7. Cabrera CV, Alonso MC, Johnston P, Phillips RG, Lawrence PA. Phenocopies induced with antisense RNA identify the wingless gene. Cell. 1987;50(4): 659-63.

8. Rijsewijk F, Schuermann M, Wagenaar E, Parren P, Weigel D, Nusse R. The Drosophila homolog of the mouse mammary oncogene int-1 is identical to the segment polarity gene wingless. Cell. 1987;50(4):649-57.

9. Wend P, Runke S, Wend K, Anchondo B, Yesayan M, Jardon M, Hardie N, Loddenkemper C, Ulasov I, Lesniak MS, et al. WNT10B/beta-catenin signalling induces HMGA2 and proliferation in metastatic triple-negative breast cancer. EMBO Mol Med. 2013;5(2):264-79.

10. Luga V, Zhang L, Viloria-Petit AM, Ogunjimi AA, Inanlou MR, Chiu E, Buchanan M, Hosein AN, Basik M, Wrana JL. Exosomes mediate stromal mobilization of autocrine Wnt-PCP signaling in breast cancer cell migration. Cell. 2012;151(7):1542-56.

11. Harper KL, Sosa MS, Entenberg D, Hosseini H, Cheung JF, Nobre R, AvivarValderas A, Nagi C, Girnius N, Davis RJ, et al. Mechanism of early dissemination and metastasis in Her2(+) mammary cancer. Nature. 2016;540(7634):588-92.

12. Malladi $S$, Macalinao DG, Jin X, He L, Basnet $H$, Zou Y, de Stanchina E, Massague J. Metastatic latency and immune evasion through autocrine inhibition of WNT. Cell. 2016;165(1):45-60.

13. Wang $X$, Jung $Y S$, Jun $S$, Lee $S$, Wang $W$, Schneider $A$, Sun Oh $Y$, Lin SH, Park BJ, Chen J, et al. PAF-Wnt signaling-induced cell plasticity is required for maintenance of breast cancer cell stemness. Nat Commun. 2016;7:10633.

14. Piva M, Domenici G, Iriondo O, Rabano M, Simoes BM, Comaills V, Barredo I, Lopez-Ruiz JA, Zabalza I, Kypta R, et al. Sox2 promotes tamoxifen resistance in breast cancer cells. EMBO Mol Med. 2014;6(1):66-79.

15. Shi J, Wang Y, Zeng L, Wu Y, Deng J, Zhang Q, Lin Y, Li J, Kang T, Tao M, et al. Disrupting the interaction of BRD4 with diacetylated twist suppresses tumorigenesis in basal-like breast cancer. Cancer Cell. 2014;25(2):210-25.

16. Jiang S, Zhang M, Zhang Y, Zhou W, Zhu T, Ruan Q, Chen H, Fang J, Zhou F, Sun J, et al. WNT5B governs the phenotype of basal-like breast cancer by activating WNT signaling. Cell Commun Signal. 2019;17(1):109.

17. Kahn M. Can we safely target the WNT pathway? Nat Rev Drug Discov. 2014;13(7):513-32.

18. Staal FJ, Clevers HC. WNT signalling and haematopoiesis: a WNT-WNT situation. Nat Rev Immunol. 2005;5(1):21-30.
19. Sidaway P. Prostate cancer: Wnt signalling induces resistance. Nat Rev Urol. 2015;12(11):597.

20. Niehrs C. The complex world of WNT receptor signalling. Nat Rev Mol Cell Biol. 2012;13(12):767-79.

21. Shipitsin M, Campbell LL, Argani P, Weremowicz S, Bloushtain-Qimron N, Yao J, Nikolskaya T, Serebryiskaya T, Beroukhim R, Hu M, et al. Molecular definition of breast tumor heterogeneity. Cancer Cell. 2007;11(3):259-73.

22. Gujral TS, Chan M, Peshkin L, Sorger PK, Kirschner MW, MacBeath G. A noncanonical Frizzled2 pathway regulates epithelial-mesenchymal transition and metastasis. Cell. 2014;159(4):844-56.

23. Prasad CP, Chaurasiya SK, Axelsson L, Andersson T. WNT-5A triggers Cdc42 activation leading to an ERK1/2 dependent decrease in MMP9 activity and invasive migration of breast cancer cells. Mol Oncol. 2013;7(5):870-83.

24. Cleary AS, Leonard TL, Gestl SA, Gunther EJ. Tumour cell heterogeneity maintained by cooperating subclones in Wnt-driven mammary cancers. Nature. 2014;508(7494):113-7.

25. Ayyanan A, Civenni G, Ciarloni L, Morel C, Mueller N, Lefort K, Mandinova A, Raffoul W, Fiche M, Dotto GP, et al. Increased Wnt signaling triggers oncogenic conversion of human breast epithelial cells by a notchdependent mechanism. Proc Natl Acad Sci U S A. 2006;103(10):3799-804.

26. Wong SC, Lo SF, Lee KC, Yam JW, Chan JK, Wendy Hsiao WL. Expression of frizzled-related protein and Wnt-signalling molecules in invasive human breast tumours. J Pathol. 2002;196(2):145-53.

27. Huguet EL, McMahon JA, McMahon AP, Bicknell R, Harris AL. Differential expression of human Wnt genes 2, 3, 4, and 7B in human breast cell lines and normal and disease states of human breast tissue. Cancer Res. 1994; 54(10):2615-21.

28. Dale TC, Weber-Hall SJ, Smith K, Huguet EL, Jayatilake H, Gusterson BA, Shuttleworth G, O'Hare M, Harris AL. Compartment switching of WNT-2 expression in human breast tumors. Cancer Res. 1996;56(19):4320-3.

29. Zhang M, Tsimelzon A, Chang CH, Fan C, Wolff A, Perou CM, Hilsenbeck SG, Rosen JM. Intratumoral heterogeneity in a Trp53-null mouse model of human breast cancer. Cancer Discov. 2015;5(5):520-33.

30. Xiu DH, Liu GF, Yu SN, Li LY, Zhao GQ, Liu L, Li XF. Long non-coding RNA LINC00968 attenuates drug resistance of breast cancer cells through inhibiting the Wnt2/beta-catenin signaling pathway by regulating WNT2. J Exp Clin Cancer Res. 2019;38(1):94.

31. Watanabe O, Imamura H, Shimizu T, Kinoshita J, Okabe T, Hirano A, Yoshimatsu K, Konno S, Aiba M, Ogawa K. Expression of twist and wnt in human breast cancer. Anticancer Res. 2004;24(6):3851-6.

32. Ellsworth RE, Seebach J, Field LA, Heckman C, Kane J, Hooke JA, Love B, Shriver CD. A gene expression signature that defines breast cancer metastases. Clin Exp Metastasis. 2009;26(3):205-13.

33. Ober EA, Verkade H, Field HA, Stainier DY. Mesodermal Wnt2b signalling positively regulates liver specification. Nature. 2006;442(7103):688-91.

34. Chang WL, Wu H, Chiu YK, Wang S, Jiang TX, Luo ZL, Lin YC, Li A, Hsu JT, Huang $\mathrm{HL}$, et al. The making of a flight feather: bio-architectural principles and adaptation. Cell. 2019;179(6):1409-23 e1417.

35. Wu Y, Ginther C, Kim J, Mosher N, Chung S, Slamon D, Vadgama JV. Expression of Wnt3 activates Wnt/beta-catenin pathway and promotes EMTlike phenotype in trastuzumab-resistant HER2-overexpressing breast cancer cells. Mol Cancer Res. 2012;10(12):1597-606.

36. Gong C, Qu S, Lv XB, Liu B, Tan W, Nie Y, Su F, Liu Q, Yao H, Song E. BRMS1L suppresses breast cancer metastasis by inducing epigenetic silence of FZD10. Nat Commun. 2014:5:5406.

37. Wu Y, Tran T, Dwabe S, Sarkissyan M, Kim J, Nava M, Clayton S, Pietras R, Farias-Eisner R, Vadgama JV. A83-01 inhibits TGF-beta-induced upregulation of Wnt3 and epithelial to mesenchymal transition in HER2overexpressing breast cancer cells. Breast Cancer Res Treat. 2017;163(3): 449-60.

38. Joshi PA, Jackson HW, Beristain AG, Di Grappa MA, Mote PA, Clarke $C L$, Stingl J, Waterhouse PD, Khokha R. Progesterone induces adult mammary stem cell expansion. Nature. 2010;465(7299):803-7.

39. Sikora MJ, Jacobsen BM, Levine K, Chen J, Davidson NE, Lee AV, Alexander CM, Oesterreich S. WNT4 mediates estrogen receptor signaling and endocrine resistance in invasive lobular carcinoma cell lines. Breast Cancer Res. 2016;18(1):92.

40. Lejeune S, Huguet EL, Hamby A, Poulsom R, Harris AL. Wnt5a cloning, expression, and up-regulation in human primary breast cancers. Clin Cancer Res. 1995:1(2):215-22. 
41. Kessenbrock K, Dijkgraaf GJ, Lawson DA, Littlepage LE, Shahi P, Pieper $U$, Werb $Z$. A role for matrix metalloproteinases in regulating mammary stem cell function via the Wnt signaling pathway. Cell Stem Cell. 2013; 13(3):300-13.

42. Samanta S, Guru S, Elaimy AL, Amante JJ, Ou J, Yu J, Zhu LJ, Mercurio AM. IMP3 stabilization of WNT5B mRNA facilitates TAZ activation in breast Cancer. Cell Rep. 2018;23(9):2559-67.

43. Klemm F, Bleckmann A, Siam L, Chuang HN, Rietkotter E, Behme D, Schulz M, Schaffrinski M, Schindler S. Trumper $L$ et al: beta-catenin-independent WNT signaling in basal-like breast cancer and brain metastasis. Carcinogenesis. 2011;32(3):434-42.

44. Avgustinova A, Iravani M, Robertson D, Fearns A, Gao Q, Klingbeil P, Hanby AM, Speirs V, Sahai E, Calvo F, et al. Tumour cell-derived Wnt7a recruits and activates fibroblasts to promote tumour aggressiveness. Nat Commun. 2016; 7:10305.

45. Sundqvist A, Morikawa M, Ren J, Vasilaki E, Kawasaki N, Kobayashi M, Koinuma D, Aburatani $\mathrm{H}$, Miyazono K, Heldin $\mathrm{CH}$, et al. JUNB governs a feed-forward network of TGFbeta signaling that aggravates breast cancer invasion. Nucleic Acids Res. 2018;46(3):1180-95.

46. Yeo EJ, Cassetta L, Qian BZ, Lewkowich I, Li JF, Stefater JA 3rd, Smith AN, Wiechmann LS, Wang Y, Pollard JW, et al. Myeloid WNT7b mediates the angiogenic switch and metastasis in breast cancer. Cancer Res. 2014;74(11): 2962-73.

47. Mattes B, Dang Y, Greicius G, Kaufmann LT, Prunsche B, Rosenbauer J, Stegmaier J, Mikut R, Ozbek S, Nienhaus GU, et al. Wnt/PCP controls spreading of Wnt/beta-catenin signals by cytonemes in vertebrates. Elife. 2018;7.

48. Fang Z, Liu X, Wen J, Tang F, Zhou Y, Jing N, Jin Y. SOX21 ensures rostral forebrain identity by suppression of WNT8B during neural regionalization of human embryonic stem cells. Stem Cell Reports. 2019;13(6):1038-52.

49. Grainger S, Nguyen N, Richter J, Setayesh J, Lonquich B, Oon CH, Wozniak JM, Barahona R, Kamei CN, Houston J, et al. EGFR is required for Wnt9aFzd9b signalling specificity in haematopoietic stem cells. Nat Cell Biol. 2019; 21(6):721-30.

50. Karner CM, Chirumamilla R, Aoki S, Igarashi P, Wallingford JB, Carroll TJ. Wnt9b signaling regulates planar cell polarity and kidney tubule morphogenesis. Nat Genet. 2009;41(7):793-9.

51. Carroll TJ, Park JS, Hayashi S, Majumdar A, McMahon AP. Wnt9b plays a central role in the regulation of mesenchymal to epithelial transitions underlying organogenesis of the mammalian urogenital system. Dev Cell. 2005;9(2):283-92.

52. Goddard LM, Duchemin AL, Ramalingan H, Wu B, Chen M, Bamezai S, Yang J, Li L, Morley MP, Wang T, et al. Hemodynamic forces sculpt developing heart valves through a KLF2-WNT9B paracrine signaling Axis. Dev Cell. 2017; 43(3):274-89 e275

53. Matsunaga N, Ogino T, Hara Y, Tanaka T, Koyanagi S, Ohdo S. Optimized dosing schedule based on circadian dynamics of mouse breast Cancer stem cells improves the antitumor effects of aldehyde dehydrogenase inhibitor. Cancer Res. 2018;78(13):3698-708.

54. Chen $Y$, Zeng C, Zhan Y, Wang H, Jiang X, Li W. Aberrant low expression of p85alpha in stromal fibroblasts promotes breast cancer cell metastasis through exosome-mediated paracrine Wnt10b. Oncogene. 2017;36(33): 4692-705.

55. El Ayachi I, Fatima I, Wend P, Alva-Ornelas JA, Runke S, Kuenzinger WL, Silva J, Silva W, Gray JK, Lehr S, et al. The WNT10B network is associated with survival and metastases in Chemoresistant triple-negative breast Cancer. Cancer Res. 2019;79(5):982-93.

56. Bui TD, Rankin J, Smith K, Huguet EL, Ruben S, Strachan T, Harris AL, Lindsay S. A novel human WNT gene, WNT10B, maps to $12 q 13$ and is expressed in human breast carcinomas. Oncogene. 1997;14(10):1249-53.

57. Dwyer MA, Joseph JD, Wade HE, Eaton ML, Kunder RS, Kazmin D, Chang CY, McDonnell DP. WNT11 expression is induced by estrogen-related receptor alpha and beta-catenin and acts in an autocrine manner to increase cancer cell migration. Cancer Res. 2010;70(22):9298-308.

58. Yu KD, Zhu R, Zhan M, Rodriguez AA, Yang W, Wong S, Makris A, Lehmann $B D$, Chen $X$, Mayer I, et al. Identification of prognosis-relevant subgroups in patients with chemoresistant triple-negative breast cancer. Clin Cancer Res. 2013;19(10):2723-33.

59. Clements WK, Kim AD, Ong KG, Moore JC, Lawson ND, Traver D. A somitic Wnt16/notch pathway specifies haematopoietic stem cells. Nature. 2011; 474(7350):220-4
60. Moverare-Skrtic S, Henning P, Liu X, Nagano K, Saito H, Borjesson AE, Sjogren K, Windahl SH, Farman H, Kindlund B, et al. Osteoblast-derived WNT16 represses osteoclastogenesis and prevents cortical bone fragility fractures. Nat Med. 2014;20(11):1279-88.

61. Nalesso G, Thomas BL, Sherwood JC, Yu J, Addimanda O, Eldridge SE, Thorup AS, Dale L, Schett G, Zwerina J, et al. WNT16 antagonises excessive canonical WNT activation and protects cartilage in osteoarthritis. Ann Rheum Dis. 2017;76(1):218-26.

62. Tong W, Zeng Y, Chow DHK, Yeung W, Xu J, Deng Y, Chen S, Zhao H, Zhang $X$, Ho KK, et al. Wnt16 attenuates osteoarthritis progression through a PCP/JNK-mTORC1-PTHrP cascade. Ann Rheum Dis. 2019;78(4):551-61.

63. Liu J, Pan S, Hsieh MH, Ng N, Sun F, Wang T, Kasibhatla S, Schuller AG, Li $A G$, Cheng D, et al. Targeting Wnt-driven cancer through the inhibition of porcupine by LGK974. Proc Natl Acad Sci U S A. 2013;110(50):20224-9.

64. Lin X, Liu J, Hu SF, Hu X. Increased expression of TMED2 is an unfavorable prognostic factor in patients with breast cancer. Cancer Manag Res. 2019;11: 2203-14.

65. Lu D, Li Y, Liu QR, Wu Q, Zhang H, Xie P, Wang Q. Wls promotes the proliferation of breast cancer cells via Wnt signaling. Med Oncol. 2015;32(5):140.

66. Sulli G, D'Elia E, Moroni MC. The Frizzled-ligand Norrin acts as a tumour suppressor linking oncogenic RAS signalling to p53. bioRxiv; 2019.

67. Cai C, Yu QC, Jiang W, Liu W, Song W, Yu H, Zhang L, Yang Y, Zeng YA. Rspondin1 is a novel hormone mediator for mammary stem cell self-renewal. Genes Dev. 2014;28(20):2205-18.

68. Zhang M, Rosen JM. Developmental insights into breast Cancer Intratumoral heterogeneity. Trends Cancer. 2015;1(4):242-51.

69. Suzuki H, Toyota M, Carraway H, Gabrielson E, Ohmura T, Fujikane T, Nishikawa N, Sogabe Y, Nojima M, Sonoda T, et al. Frequent epigenetic inactivation of Wnt antagonist genes in breast cancer. Br J Cancer. 2008; 98(6):1147-56

70. Veeck J, Niederacher D, An H, Klopocki E, Wiesmann F, Betz B, Galm O, Camara O, Durst M, Kristiansen G, et al. Aberrant methylation of the Wnt antagonist SFRP1 in breast cancer is associated with unfavourable prognosis. Oncogene. 2006;25(24):3479-88.

71. Lo PK, Mehrotra J, D'Costa A, Fackler MJ, Garrett-Mayer E, Argani P, Sukumar S. Epigenetic suppression of secreted frizzled related protein 1 (SFRP1) expression in human breast cancer. Cancer Biol Ther. 2006;5(3):281-6.

72. Veeck J, Geisler C, Noetzel E, Alkaya S, Hartmann A, Knuchel R, Dahl E. Epigenetic inactivation of the secreted frizzled-related protein-5 (SFRP5) gene in human breast cancer is associated with unfavorable prognosis. Carcinogenesis. 2008;29(5):991-8.

73. Veeck J, Noetzel E, Bektas N, Jost E, Hartmann A, Knuchel R, Dahl E. Promoter hypermethylation of the SFRP2 gene is a high-frequent alteration and tumor-specific epigenetic marker in human breast cancer. Mol Cancer. 2008;7:83.

74. Bernemann C, Hulsewig C, Ruckert C, Schafer S, Blumel L, Hempel G, Gotte M, Greve B, Barth PJ, Kiesel L, et al. Influence of secreted frizzled receptor protein 1 (SFRP1) on neoadjuvant chemotherapy in triple negative breast cancer does not rely on WNT signaling. Mol Cancer. 2014;13:174.

75. Trifa F, Karray-Chouayekh S, Jmal E, Jmaa ZB, Khabir A, Sellami-Boudawara T, Frikha M, Daoud J, Mokdad-Gargouri R. Loss of WIF-1 and Wnt5a expression is related to aggressiveness of sporadic breast cancer in Tunisian patients. Tumour Biol. 2013;34(3):1625-33.

76. Ai L, Tao Q, Zhong S, Fields CR, Kim WJ, Lee MW, Cui Y, Brown KD, Robertson KD. Inactivation of Wnt inhibitory factor-1 (WIF1) expression by epigenetic silencing is a common event in breast cancer. Carcinogenesis. 2006;27(7):1341-8.

77. Mendoza-Villanueva D, Zeef L, Shore P. Metastatic breast cancer cells inhibit osteoblast differentiation through the Runx2/CBFbeta-dependent expression of the Wnt antagonist, sclerostin. Breast Cancer Res. 2011;13(5):R106.

78. Ryan AJ, Napoletano S, Fitzpatrick PA, Currid CA, O'Sullivan NC, Harmey JH. Expression of a protease-resistant insulin-like growth factor-binding protein4 inhibits tumour growth in a murine model of breast cancer. $\mathrm{Br} J$ Cancer. 2009;101(2):278-86.

79. Xiao Q, Chen Z, Jin X, Mao R, Chen Z. The many postures of noncanonical Wnt signaling in development and diseases. Biomed Pharmacother. 2017;93: 359-69.

80. Willert K, Brown JD, Danenberg E, Duncan AW, Weissman IL, Reya T, Yates JR 3rd, Nusse R. Wht proteins are lipid-modified and can act as stem cell growth factors. Nature. 2003;423(6938):448-52. 
81. Port F, Hausmann G, Basler K. A genome-wide RNA interference screen uncovers two p24 proteins as regulators of wingless secretion. EMBO Rep. 2011;12(11):1144-52.

82. Buechling T, Chaudhary V, Spirohn K, Weiss M, Boutros M. p24 proteins are required for secretion of Wnt ligands. EMBO Rep. 2011;12(12):1265-72.

83. Aber R, Chan W, Mugisha S, Jerome-Majewska LA. Transmembrane emp24 domain proteins in development and disease. Genet Res (Camb). 2019;101:e14.

84. Yu J, Chia J, Canning CA, Jones CM, Bard FA, Virshup DM. WLS retrograde transport to the endoplasmic reticulum during Wnt secretion. Dev Cell. 2014:29(3):277-91.

85. Banziger C, Soldini D, Schutt C, Zipperlen P, Hausmann G, Basler K. Wntless, a conserved membrane protein dedicated to the secretion of Wnt proteins from signaling cells. Cell. 2006;125(3):509-22.

86. Fu J, Jiang M, Mirando AJ, Yu HM, Hsu W. Reciprocal regulation of Wnt and Gpr177/mouse Wntless is required for embryonic axis formation. Proc Natl Acad Sci U S A. 2009;106(44):18598-603

87. Goodman RM, Thombre S, Firtina Z, Gray D, Betts D, Roebuck J, Spana EP Selva EM. Sprinter: a novel transmembrane protein required for $\mathrm{Wg}$ secretion and signaling. Development. 2006;133(24):4901-11.

88. Franch-Marro X, Wendler F, Guidato S, Griffith J, Baena-Lopez A, Itasaki N, Maurice MM, Vincent JP. Wingless secretion requires endosome-to-Golgi retrieval of Wntless/Evi/sprinter by the retromer complex. Nat Cell Biol. 2008;10(2):170-7.

89. Port F, Kuster M, Herr P, Furger E, Banziger C, Hausmann G, Basler K. Wingless secretion promotes and requires retromer-dependent cycling of Wntless. Nat Cell Biol. 2008;10(2):178-85.

90. Nusse R, Clevers H. Wnt/beta-catenin signaling, disease, and emerging therapeutic modalities. Cell. 2017;169(6):985-99.

91. Korkut C, Ataman B, Ramachandran P, Ashley J, Barria R, Gherbesi N, Budnik V. Trans-synaptic transmission of vesicular Wnt signals through Evi/Wntless. Cell. 2009;139(2):393-404

92. Gross JC, Chaudhary V, Bartscherer K, Boutros M. Active Wnt proteins are secreted on exosomes. Nat Cell Biol. 2012;14(10):1036-45.

93. Zhang $L$, Wrana JL. The emerging role of exosomes in Wht secretion and transport. Curr Opin Genet Dev. 2014;27:14-9.

94. Kakugawa S, Langton PF, Zebisch M, Howell S, Chang TH, Liu Y, Feizi T, Bineva G, O'Reilly N, Snijders AP, et al. Notum deacylates Wnt proteins to suppress signalling activity. Nature. 2015;519(7542):187-92.

95. Zhang X, Cheong SM, Amado NG, Reis AH, MacDonald BT, Zebisch M, Jones EY, Abreu JG, He X. Notum is required for neural and head induction via Wnt deacylation, oxidation, and inactivation. Dev Cell. 2015;32(6):719-30

96. Bhanot P, Brink M, Samos CH, Hsieh JC, Wang Y, Macke JP, Andrew D, Nathans J, Nusse R. A new member of the frizzled family from Drosophila functions as a wingless receptor. Nature. 1996:382(6588):225-30.

97. Dann CE, Hsieh JC, Rattner A, Sharma D, Nathans J, Leahy DJ. Insights into Wnt binding and signalling from the structures of two frizzled cysteine-rich domains. Nature. 2001;412(6842):86-90.

98. Janda CY, Waghray D, Levin AM, Thomas C, Garcia KC. Structural basis of Wnt recognition by frizzled. Science. 2012;337(6090):59-64.

99. Wehrli M, Dougan ST, Caldwell K, O'Keefe L, Schwartz S, Vaizel-Ohayon D, Schejter E, Tomlinson A. DiNardo S: arrow encodes an LDL-receptor-related protein essential for wingless signalling. Nature. 2000:407(6803):527-30.

100. Tamai K, Semenov M, Kato Y, Spokony R, Liu C, Katsuyama Y, Hess F, SaintJeannet JP, He X. LDL-receptor-related proteins in Wnt signal transduction. Nature. 2000;407(6803):530-5.

101. Pinson KI, Brennan J, Monkley S, Avery BJ, Skarnes WC. An LDL-receptor-related protein mediates Wnt signalling in mice. Nature. 2000;407(6803):535-8.

102. Hsieh JC, Kodjabachian L, Rebbert ML, Rattner A, Smallwood PM, Samos CH, Nusse R, Dawid IB, Nathans J. A new secreted protein that binds to Wnt proteins and inhibits their activities. Nature. 1999;398(6726):431-6.

103. Piccolo S, Agius E, Leyns L, Bhattacharyya S, Grunz H, Bouwmeester T, De Robertis EM. The head inducer Cerberus is a multifunctional antagonist of nodal. BMP and Wnt signals Nature. 1999:397(6721):707-10

104. Rattner A, Hsieh JC, Smallwood PM, Gilbert DJ, Copeland NG, Jenkins NA, Nathans J. A family of secreted proteins contains homology to the cysteinerich ligand-binding domain of frizzled receptors. Proc Natl Acad Sci U S A. 1997:94(7):2859-63.

105. Itasaki N, Jones CM, Mercurio S, Rowe A, Domingos PM, Smith JC, Krumlauf R. Wise, a context-dependent activator and inhibitor of Wnt signalling. Development. 2003;130(18):4295-305.
106. Lintern KB, Guidato S, Rowe A, Saldanha JW, Itasaki N. Characterization of wise protein and its molecular mechanism to interact with both Wnt and BMP signals. J Biol Chem. 2009;284(34):23159-68.

107. Semenov M, Tamai $K$, He X. SOST is a ligand for LRP5/LRP6 and a Wnt signaling inhibitor. J Biol Chem. 2005;280(29):26770-5.

108. Glinka A, Wu W, Delius H, Monaghan AP, Blumenstock C, Niehrs C. Dickkopf1 is a member of a new family of secreted proteins and functions in head induction. Nature. 1998;391(6665):357-62.

109. Mao B, Wu W, Li Y, Hoppe D, Stannek P, Glinka A, Niehrs C. LDL-receptorrelated protein 6 is a receptor for Dickkopf proteins. Nature. 2001;411(6835): $321-5$.

110. Zhu W, Shiojima I, Ito Y, Li Z, Ikeda H, Yoshida M, Naito AT, Nishi J, Ueno H, Umezawa A, et al. IGFBP-4 is an inhibitor of canonical Wnt signalling required for cardiogenesis. Nature. 2008;454(7202):345-9.

111. Bafico A, Gazit A, Pramila T, Finch PW, Yaniv A, Aaronson SA. Interaction of frizzled related protein (FRP) with Wnt ligands and the frizzled receptor suggests alternative mechanisms for FRP inhibition of Wnt signaling. J Biol Chem. 1999;274(23):16180-7.

112. Rodriguez J, Esteve $P$, Weinl C, Ruiz JM, Fermin Y, Trousse F, Dwivedy A, Holt C, Bovolenta P. SFRP1 regulates the growth of retinal ganglion cell axons through the Fz2 receptor. Nat Neurosci. 2005;8(10):1301-9.

113. Koo BK, Spit M, Jordens I, Low TY, Stange DE, van de Wetering M, van Es JH, Mohammed S, Heck AJ, Maurice MM, et al. Tumour suppressor RNF43 is a stem-cell E3 ligase that induces endocytosis of Wnt receptors. Nature. 2012; 488(7413):665-9.

114. Hao HX, Xie Y, Zhang Y, Charlat O, Oster E, Avello M, Lei H, Mickanin C, Liu

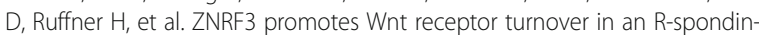
sensitive manner. Nature. 2012:485(7397):195-200.

115. Ozawa M, Baribault $H$, Kemler R. The cytoplasmic domain of the cell adhesion molecule uvomorulin associates with three independent proteins structurally related in different species. EMBO J. 1989;8(6):1711-7.

116. McCrea PD, Gumbiner BM. Purification of a $92-k D a$ cytoplasmic protein tightly associated with the cell-cell adhesion molecule E-cadherin (uvomorulin). Characterization and extractability of the protein complex from the cell cytostructure. J Biol Chem. 1991;266(7):4514-20.

117. McCrea PD, Turck CW, Gumbiner B. A homolog of the armadillo protein in Drosophila (plakoglobin) associated with E-cadherin. Science. 1991; 254(5036):1359-61.

118. Hulsken J, Birchmeier W, Behrens J. E-cadherin and APC compete for the interaction with beta-catenin and the cytoskeleton. J Cell Biol. 1994;127(6 Pt 2):2061-9.

119. Rubinfeld B, Souza B, Albert I, Muller O, Chamberlain SH, Masiarz FR, Munemitsu S, Polakis P. Association of the APC gene product with betacatenin. Science. 1993;262(5140):1731-4.

120. Munemitsu S, Albert I, Souza B, Rubinfeld B, Polakis P. Regulation of intracellular beta-catenin levels by the adenomatous polyposis coli (APC) tumor-suppressor protein. Proc Natl Acad Sci U S A. 1995;92(7):3046-50.

121. Zeng L, Fagotto F, Zhang T, Hsu W, Vasicek TJ, Perry WL 3rd, Lee J J, Tilghman SM, Gumbiner BM, Costantini F. The mouse fused locus encodes Axin, an inhibitor of the Wnt signaling pathway that regulates embryonic axis formation. Cell. 1997;90(1):181-92.

122. Hart MJ. de los Santos R, Albert IN, Rubinfeld B, Polakis P: downregulation of beta-catenin by human Axin and its association with the APC tumor suppressor, beta-catenin and GSK3 beta. Curr Biol. 1998;8(10):573-81.

123. Mao J, Wang J, Liu B, Pan W, Farr GH 3rd, Flynn C, Yuan H, Takada S, Kimelman D, Li L, et al. Low-density lipoprotein receptor-related protein-5 binds to Axin and regulates the canonical Wnt signaling pathway. Mol Cell. 2001;7(4):801-9.

124. Ikeda S, Kishida S, Yamamoto H, Murai H, Koyama S, Kikuchi A. Axin, a negative regulator of the Wnt signaling pathway, forms a complex with GSK-3beta and beta-catenin and promotes GSK-3beta-dependent phosphorylation of beta-catenin. EMBO J. 1998;17(5):1371-84

125. Peifer M, Pai LM, Casey M. Phosphorylation of the Drosophila adherens junction protein Armadillo: roles for wingless signal and zeste-white 3 kinase. Dev Biol. 1994;166(2):543-56.

126. Yost C, Torres M, Miller JR, Huang E, Kimelman D, Moon RT. The axisinducing activity, stability, and subcellular distribution of beta-catenin is regulated in Xenopus embryos by glycogen synthase kinase 3. Genes Dev. $1996 \cdot 10(12) \cdot 1443-54$ 
127. Liu C, Li Y, Semenov M, Han C, Baeg GH, Tan Y, Zhang Z, Lin X, He X. Control of beta-catenin phosphorylation/degradation by a dual-kinase mechanism. Cell. 2002;108(6):837-47.

128. Amit S, Hatzubai A, Birman Y, Andersen JS, Ben-Shushan E, Mann M, BenNeriah Y, Alkalay I. Axin-mediated CKI phosphorylation of beta-catenin at Ser 45: a molecular switch for the Wnt pathway. Genes Dev. 2002;16(9): 1066-76.

129. Seeling JM, Miller JR, Gil R, Moon RT, White R, Virshup DM. Regulation of beta-catenin signaling by the B56 subunit of protein phosphatase $2 \mathrm{~A}$. Science. 1999;283(5410):2089-91.

130. Major MB, Camp ND, Berndt JD, Yi X, Goldenberg SJ, Hubbert C, Biechele TL, Gingras AC, Zheng N, Maccoss MJ, et al. Wilms tumor suppressor WTX negatively regulates WNT/beta-catenin signaling. Science. 2007;316(5827):1043-6.

131. Wu G, Xu G, Schulman BA, Jeffrey PD, Harper JW, Pavletich NP. Structure of a beta-TrCP1-Skp1-beta-catenin complex: destruction motif binding and lysine specificity of the SCF (beta-TrCP1) ubiquitin ligase. Mol Cell. 2003; 11(6):1445-56.

132. Stamos JL, Weis WI. The beta-catenin destruction complex. Cold Spring Harb Perspect Biol. 2013;5(1):a007898.

133. Huang SM, Mishina YM, Liu S, Cheung A, Stegmeier F, Michaud GA, Charlat $O$, Wiellette $E$, Zhang $Y$, Wiessner $S$, et al. Tankyrase inhibition stabilizes axin and antagonizes Wnt signalling. Nature. 2009;461(7264):614-20.

134. Liu J, Stevens J, Rote CA, Yost HJ, Hu Y, Neufeld KL, White RL, Matsunami N. Siah-1 mediates a novel beta-catenin degradation pathway linking p53 to the adenomatous polyposis coli protein. Mol Cell. 2001;7(5):927-36.

135. Roose J, Molenaar M, Peterson J, Hurenkamp J, Brantjes H, Moerer P, van de Wetering $\mathrm{M}$, Destree $\mathrm{O}$, Clevers $\mathrm{H}$. The Xenopus Wnt effector XTcf-3 interacts with Groucho-related transcriptional repressors. Nature. 1998; 395(6702):608-12.

136. Cavallo RA, Cox RT, Moline MM, Roose J, Polevoy GA, Clevers H, Peifer M, Bejsovec A. Drosophila Tcf and Groucho interact to repress wingless signalling activity. Nature. 1998;395(6702):604-8.

137. Brannon M, Brown JD, Bates R, Kimelman D, Moon RT. XCtBP is a XTcf-3 corepressor with roles throughout Xenopus development. Development. 1999; 126(14):3159-70.

138. Ye F, Chen Y, Hoang T, Montgomery RL, Zhao XH, Bu H, Hu T, Taketo MM, van Es JH, Clevers $\mathrm{H}$, et al. HDAC1 and HDAC2 regulate oligodendrocyte differentiation by disrupting the beta-catenin-TCF interaction. Nat Neurosci. 2009;12(7):829-38.

139. Billin AN, Thirlwell H, Ayer DE. Beta-catenin-histone deacetylase interactions regulate the transition of LEF1 from a transcriptional repressor to an activator. Mol Cell Biol. 2000;20(18):6882-90.

140. Staal FJ, Luis TC, Tiemessen MM. WNT signalling in the immune system: WNT is spreading its wings. Nat Rev Immunol. 2008;8(8):581-93.

141. Daniels DL, Weis WI. ICAT inhibits beta-catenin binding to Tcf/Lef-family transcription factors and the general coactivator p300 using independent structural modules. Mol Cell. 2002;10(3):573-84.

142. Takemaru K, Yamaguchi S, Lee YS, Zhang Y, Carthew RW, Moon RT. Chibby, a nuclear beta-catenin-associated antagonist of the Wnt/wingless pathway. Nature. 2003;422(6934):905-9.

143. Xu Q, Wang Y, Dabdoub A, Smallwood PM, Williams J, Woods C, Kelley MW, Jiang L, Tasman W, Zhang K, et al. Vascular development in the retina and inner ear: control by Norrin and Frizzled-4, a high-affinity ligand-receptor pair. Cell. 2004;116(6):883-95.

144. Junge HJ, Yang S, Burton JB, Paes K, Shu X, French DM, Costa M, Rice DS, Ye W. TSPAN12 regulates retinal vascular development by promoting Norrin- but not Wnt-induced FZD4/beta-catenin signaling. Cell. 2009;139(2):299-311.

145. Ke J, Harikumar KG, Erice C, Chen C, Gu X, Wang L, Parker N, Cheng Z, Xu W, Williams BO, et al. Structure and function of Norrin in assembly and activation of a frizzled 4-Lrp5/6 complex. Genes Dev. 2013;27(21):2305-19.

146. Zeng X, Tamai K, Doble B, Li S, Huang H, Habas R, Okamura H, Woodgett J, He X. A dual-kinase mechanism for Wnt co-receptor phosphorylation and activation. Nature. 2005;438(7069):873-7.

147. Davidson G, Wu W, Shen J, Bilic J, Fenger U, Stannek P, Glinka A, Niehrs C. Casein kinase 1 gamma couples Wnt receptor activation to cytoplasmic signal transduction. Nature. 2005;438(7069):867-72.

148. Tamai $K$, Zeng X, Liu C, Zhang X, Harada Y, Chang Z, He X. A mechanism for Wnt coreceptor activation. Mol Cell. 2004;13(1):149-56.

149. Wong HC, Bourdelas A, Krauss A, Lee HJ, Shao Y, Wu D, Mlodzik M, Shi DL, Zheng J. Direct binding of the PDZ domain of Dishevelled to a conserved internal sequence in the C-terminal region of frizzled. Mol Cell. 2003;12(5): 1251-60.

150. Murillo-Garzon V, Kypta R. WNT signalling in prostate cancer. Nat Rev Urol. 2017;14(11):683-96.

151. Wu X, Tu X, Joeng KS, Hilton MJ, Williams DA, Long F. Rac1 activation controls nuclear localization of beta-catenin during canonical Wnt signaling. Cell. 2008;133(2):340-53.

152. Rubinfeld B, Robbins P, El-Gamil M, Albert I, Porfiri E, Polakis P. Stabilization of beta-catenin by genetic defects in melanoma cell lines. Science. 1997; 275(5307):1790-2.

153. Behrens J, von Kries JP, Kuhl M, Bruhn L, Wedlich D, Grosschedl R, Birchmeier W. Functional interaction of beta-catenin with the transcription factor LEF-1. Nature. 1996:382(6592):638-42.

154. Molenaar M, van de Wetering M, Oosterwegel M, Peterson-Maduro J, Godsave S, Korinek V, Roose J, Destree O, Clevers H. XTcf-3 transcription factor mediates beta-catenin-induced axis formation in Xenopus embryos. Cell. 1996;86(3):391-9.

155. Korinek V, Barker N, Morin PJ, van Wichen D, de Weger R, Kinzler KW, Vogelstein $\mathrm{B}$, Clevers $\mathrm{H}$. Constitutive transcriptional activation by a beta-catenin-Tcf complex in APC-/- colon carcinoma. Science. 1997;275(5307):1784-7.

156. Morin PJ, Sparks AB, Korinek V, Barker N, Clevers H, Vogelstein B, Kinzler KW. Activation of beta-catenin-Tcf signaling in colon cancer by mutations in beta-catenin or APC. Science. 1997;275(5307):1787-90.

157. Hecht A, Vleminckx K, Stemmler MP, van Roy F, Kemler R. The p300/CBP acetyltransferases function as transcriptional coactivators of beta-catenin in vertebrates. EMBO J. 2000;19(8):1839-50.

158. Kramps T, Peter O, Brunner E, Nellen D, Froesch B, Chatterjee S, Murone M, Zullig S, Basler K. Wnt/wingless signaling requires BCL9/legless-mediated recruitment of pygopus to the nuclear beta-catenin-TCF complex. Cell. 2002:109(1):47-60

159. Townsley FM, Cliffe A, Bienz M. Pygopus and legless target Armadillo/betacatenin to the nucleus to enable its transcriptional co-activator function. Nat Cell Biol. 2004;6(7):626-33.

160. Yang Y, Mlodzik M. Wnt-frizzled/planar cell polarity signaling: cellular orientation by facing the wind (Wnt). Annu Rev Cell Dev Biol. 2015;31:623-46.

161. Butler MT, Wallingford JB. Planar cell polarity in development and disease. Nat Rev Mol Cell Biol. 2017;18(6):375-88.

162. Katoh M. WNT/PCP signaling pathway and human cancer (review). Oncol Rep. 2005;14(6):1583-8.

163. Cruciat CM, Niehrs C. Secreted and transmembrane wnt inhibitors and activators. Cold Spring Harb Perspect Biol. 2013;5(3):a015081.

164. Adler PN, Zhu C, Stone D. Inturned localizes to the proximal side of wing cells under the instruction of upstream planar polarity proteins. Curr Biol. 2004;14(22):2046-51.

165. Jenny A, Reynolds-Kenneally J, Das G, Burnett M, Mlodzik M. Diego and Prickle regulate frizzled planar cell polarity signalling by competing for Dishevelled binding. Nat Cell Biol. 2005;7(7):691-7.

166. Narimatsu M, Bose R, Pye M, Zhang L, Miller B, Ching P, Sakuma R, Luga V, Roncari L, Attisano L, et al. Regulation of planar cell polarity by Smurf ubiquitin ligases. Cell. 2009;137(2):295-307.

167. Vinson CR, Adler PN. Directional non-cell autonomy and the transmission of polarity information by the frizzled gene of Drosophila. Nature. 1987; 329(6139):549-51.

168. Vinson CR, Conover S, Adler PN. A Drosophila tissue polarity locus encodes a protein containing seven potential transmembrane domains. Nature. 1989; 338(6212):263-4

169. Wang Y, Guo N, Nathans J. The role of Frizzled3 and Frizzled6 in neural tube closure and in the planar polarity of inner-ear sensory hair cells. J Neurosci. 2006;26(8):2147-56.

170. Guo N, Hawkins C, Nathans J. Frizzled6 controls hair patterning in mice. Proc Natl Acad Sci U S A. 2004:101(25):9277-81.

171. Usui T, Shima Y, Shimada Y, Hirano S, Burgess RW, Schwarz TL, Takeichi M, Uemura T. Flamingo, a seven-pass transmembrane cadherin, regulates planar cell polarity under the control of frizzled. Cell. 1999;98(5):585-95

172. Das G, Reynolds-Kenneally J, Mlodzik M. The atypical cadherin flamingo links frizzled and notch signaling in planar polarity establishment in the Drosophila eye. Dev Cell. 2002;2(5):655-66.

173. Curtin JA, Quint E, Tsipouri V, Arkell RM, Cattanach B, Copp AJ, Henderson DJ, Spurr N, Stanier P, Fisher EM, et al. Mutation of Celsr1 disrupts planar polarity of inner ear hair cells and causes severe neural tube defects in the mouse. Curr Biol. 2003;13(13):1129-33. 
174. Montcouquiol M, Rachel RA, Lanford PJ, Copeland NG, Jenkins NA, Kelley MW. Identification of Vangl2 and Scrb1 as planar polarity genes in mammals. Nature. 2003;423(6936):173-7.

175. Torban E, Kor C, Gros P. Van Gogh-like2 (strabismus) and its role in planar cell polarity and convergent extension in vertebrates. Trends Genet. 2004; 20(11):570-7.

176. Ciruna B, Jenny A, Lee D, Mlodzik M, Schier AF. Planar cell polarity signalling couples cell division and morphogenesis during neurulation. Nature. 2006; 439(7073):220-4

177. Nishimura T, Honda H, Takeichi M. Planar cell polarity links axes of spatial dynamics in neural-tube closure. Cell. 2012;149(5):1084-97.

178. Yang W, Garrett L, Feng D, Elliott G, Liu X, Wang N, Wong YM, Choi NT, Yang Y, Gao B. Wnt-induced Vangl2 phosphorylation is dose-dependently required for planar cell polarity in mammalian development. Cell Res. 2017; 27(12):1466-84.

179. Hayes MN, McCarthy K, Jin A, Oliveira ML, lyer S, Garcia SP, Sindiri S, Gryder B, Motala Z, Nielsen GP, et al. Vangl2/RhoA signaling pathway regulates stem cell self-renewal programs and growth in rhabdomyosarcoma. Cell Stem Cell. 2018;22(3):414-27 e416.

180. Fradkin LG, Dura JM, Noordermeer JN. Ryks: new partners for Wnts in the developing and regenerating nervous system. Trends Neurosci. 2010;33(2):84-92.

181. Luo ZG, Wang Q, Zhou JZ, Wang J, Luo Z, Liu M, He X, Wynshaw-Boris A, Xiong WC, Lu B, et al. Regulation of AChR clustering by Dishevelled interacting with MuSK and PAK1. Neuron. 2002;35(3):489-505.

182. Jing L, Lefebvre JL, Gordon LR, Granato M. Wht signals organize synaptic prepattern and axon guidance through the zebrafish unplugged/MuSK receptor. Neuron. 2009;61(5):721-33.

183. Gordon LR, Gribble KD, Syrett CM, Granato M. Initiation of synapse formation by Wnt-induced MuSK endocytosis. Development. 2012;139(5):1023-33.

184. Lu X, Borchers AG, Jolicoeur C, Rayburn H, Baker JC, Tessier-Lavigne M. PTK7/CCK-4 is a novel regulator of planar cell polarity in vertebrates. Nature. 2004:430(6995):93-8

185. Munoz R, Moreno M, Oliva C, Orbenes C, Larrain J. Syndecan-4 regulates non-canonical Wnt signalling and is essential for convergent and extension movements in Xenopus embryos. Nat Cell Biol. 2006;8(5):492-500.

186. Ohkawara B, Glinka A, Niehrs C. Rspo3 binds syndecan 4 and induces Wnt/ PCP signaling via clathrin-mediated endocytosis to promote morphogenesis. Dev Cell. 2011;20(3):303-14.

187. Ohkawara B, Yamamoto TS, Tada M, Ueno N. Role of glypican 4 in the regulation of convergent extension movements during gastrulation in Xenopus laevis. Development. 2003;130(10):2129-38.

188. Goffinet AM, Tissir F. Seven pass Cadherins CELSR1-3. Semin Cell Dev Biol. 2017;69:102-10

189. Puvirajesinghe TM, Bertucci $F$, Jain A, Scerbo P, Belotti $E$, Audebert $S$, Sebbagh M, Lopez M, Brech A, Finetti P, et al. Identification of p62/SQSTM1 as a component of non-canonical Wnt VANGL2-JNK signalling in breast cancer. Nat Commun. 2016;7:10318.

190. Gombos R, Migh E, Antal O, Mukherjee A, Jenny A, Mihaly J. The Formin DAAM functions as molecular effector of the planar cell polarity pathway during axonal development in Drosophila. J Neurosci. 2015;35(28):10154-67.

191. Nakaya MA, Habas R, Biris K, Dunty WC Jr, Kato Y, He X, Yamaguchi TP. Identification and comparative expression analyses of Daam genes in mouse and Xenopus. Gene Expr Patterns. 2004;5(1):97-105.

192. Aspenstrom P, Richnau N, Johansson AS. The diaphanous-related formin DAAM1 collaborates with the rho GTPases RhoA and Cdc42, CIP4 and Src in regulating cell morphogenesis and actin dynamics. Exp Cell Res. 2006;312(12):2180-94.

193. Coso OA, Chiariello M, Yu JC, Teramoto H, Crespo P, Xu N, Miki T, Gutkind JS. The small GTP-binding proteins Rac1 and Cdc42 regulate the activity of the JNK/SAPK signaling pathway. Cell. 1995;81(7):1137-46.

194. Derijard B, Hibi M, Wu IH, Barrett T, Su B, Deng T, Karin M, Davis RJ. JNK1: a protein kinase stimulated by UV light and ha-Ras that binds and phosphorylates the c-Jun activation domain. Cell. 1994;76(6):1025-37.

195. Kitzing TM, Sahadevan AS, Brandt DT, Knieling H, Hannemann S, Fackler OT, Grosshans J, Grosse R. Positive feedback between Dia1, LARG, and RhoA regulates cell morphology and invasion. Genes Dev. 2007;21(12):1478-83.

196. Eyers CE, McNeill H, Knebel A, Morrice N, Arthur SJ, Cuenda A, Cohen P. The phosphorylation of CapZ-interacting protein (CapZIP) by stress-activated protein kinases triggers its dissociation from CapZ. Biochem J. 2005;389(Pt 1):127-35.

197. Peng Y, Chen Z, Chen Y, Li S, Jiang Y, Yang H, Wu C, You F, Zheng C, Zhu J, et al. ROCK isoforms differentially modulate cancer cell motility by mechanosensing the substrate stiffness. Acta Biomater. 2019;88:86-101.
198. Barko S, Bugyi B, Carlier MF, Gombos R, Matusek T, Mihaly J, Nyitrai M. Characterization of the biochemical properties and biological function of the formin homology domains of Drosophila DAAM. J Biol Chem. 2010; 285(17):13154-69.

199. Nusse R. Wnt signaling. Cold Spring Harb Perspect Biol. 2012;4:5.

200. Semenov MV, Habas R, Macdonald BT, He X. SnapShot: noncanonical Wnt signaling pathways. Cell. 2007;131(7):1378.

201. Saneyoshi T, Kume S, Amasaki Y, Mikoshiba K. The Wnt/calcium pathway activates NF-AT and promotes ventral cell fate in Xenopus embryos. Nature. 2002;417(6886):295-9.

202. Liang H, Chen Q, Coles AH, Anderson SJ, Pihan G, Bradley A, Gerstein R, Jurecic R, Jones SN. Wnt5a inhibits B cell proliferation and functions as a tumor suppressor in hematopoietic tissue. Cancer Cell. 2003;4(5):349-60.

203. Gregory MA, Phang TL, Neviani P, Alvarez-Calderon F, Eide CA, O'Hare T, Zaberezhnyy V, Williams RT, Druker BJ, Perrotti D, et al. Wnt/Ca2+/NFAT signaling maintains survival of Ph+ leukemia cells upon inhibition of BcrAbl. Cancer Cell. 2010;18(1):74-87.

204. Zhuang X, Zhang H, Li X, Li X, Cong M, Peng F, Yu J, Zhang X, Yang Q, Hu $G$. Differential effects on lung and bone metastasis of breast cancer by Wnt signalling inhibitor DKK1. Nat Cell Biol. 2017;19(10):1274-85.

205. Vargas JY, Loria F, Wu YJ, Cordova G, Nonaka T, Bellow S, Syan S, Hasegawa M, van Woerden GM, Trollet C, et al. The Wnt/ca (2+) pathway is involved in interneuronal communication mediated by tunneling nanotubes. EMBO J. 2019;38(23):e101230

206. Mahdi T, Hanzelmann S, Salehi A, Muhammed SJ, Reinbothe TM, Tang Y, Axelsson AS, Zhou Y, Jing X, Almgren P, et al. Secreted frizzled-related protein 4 reduces insulin secretion and is overexpressed in type 2 diabetes. Cell Metab. 2012;16(5):625-33.

207. Slusarski DC, Corces VG, Moon RT. Interaction of Wnt and a frizzled homologue triggers G-protein-linked phosphatidylinositol signalling. Nature. 1997;390(6658):410-3.

208. Mikoshiba K. IP3 receptor/Ca2+ channel: from discovery to new signaling concepts. J Neurochem. 2007;102(5):1426-46.

209. Gong B, Shen W, Xiao W, Meng Y, Meng A, Jia S. The Sec14-like phosphatidylinositol transfer proteins Sec14l3/SEC14L2 act as GTPase proteins to mediate Wnt/ca (2+) signaling. Elife. 2017;6.

210. Potier M, Trebak M. New developments in the signaling mechanisms of the store-operated calcium entry pathway. Pflugers Arch. 2008;457(2):405-15.

211. Trebak M, Kinet JP. Calcium signalling in T cells. Nat Rev Immunol. 2019; 19(3):154-69.

212. Heit JJ, Apelqvist AA, Gu X, Winslow MM, Neilson JR, Crabtree GR, Kim SK. Calcineurin/NFAT signalling regulates pancreatic beta-cell growth and function. Nature. 2006;443(7109):345-9.

213. Smit L, Baas A, Kuipers J, Korswagen $H$, van de Wetering M, Clevers $H$. Wnt activates the Tak1/nemo-like kinase pathway. J Biol Chem. 2004;279(17): $17232-40$.

214. Huang T, Alvarez AA, Pangeni RP, Horbinski CM, Lu S, Kim SH, James CD. J JR, J AK, Brenann CW et al: a regulatory circuit of miR-125b/miR-20b and Wnt signalling controls glioblastoma phenotypes through FZD6-modulated pathways. Nat Commun. 2016;7:12885.

215. Raingeaud J, Gupta S, Rogers JS, Dickens M, Han J, Ulevitch RJ, Davis RJ. Pro-inflammatory cytokines and environmental stress cause p38 mitogenactivated protein kinase activation by dual phosphorylation on tyrosine and threonine. J Biol Chem. 1995;270(13):7420-6

216. Raingeaud J, Whitmarsh AJ, Barrett T, Derijard B, Davis RJ. MKK3- and MKK6-regulated gene expression is mediated by the p38 mitogenactivated protein kinase signal transduction pathway. Mol Cell Biol. 1996;16(3):1247-55

217. van Schie EH, van Amerongen R. Aberrant WNT/CTNNB1 signaling as a therapeutic target in human breast Cancer: weighing the evidence. Front Cell Dev Biol. 2020;8:25.

218. Jonsson M, Dejmek J, Bendahl PO, Andersson T. Loss of Wnt-5a protein is associated with early relapse in invasive ductal breast carcinomas. Cancer Res. 2002;62(2):409-16.

219. Dejmek J, Leandersson K, Manjer J, Bjartell A, Emdin SO, Vogel WF, Landberg G, Andersson T. Expression and signaling activity of Wnt-5a/ discoidin domain receptor-1 and Syk plays distinct but decisive roles in breast cancer patient survival. Clin Cancer Res. 2005:11(2 Pt 1):520-8.

220. Borcherding N, Kusner D, Kolb R, Xie Q, Li W, Yuan F, Velez G, Askeland R, Weigel RJ, Zhang W. Paracrine WNT5A signaling inhibits expansion of tumor-initiating cells. Cancer Res. 2015;75(10):1972-82. 
221. Safholm A, Tuomela J, Rosenkvist J, Dejmek J, Harkonen P, Andersson T. The Wnt-5a-derived hexapeptide Foxy-5 inhibits breast cancer metastasis in vivo by targeting cell motility. Clin Cancer Res. 2008;14(20):6556-63.

222. Berx G, Cleton-Jansen AM, Nollet F, de Leeuw WJ, van de Vijver M, Cornelisse C, van Roy F. E-cadherin is a tumour/invasion suppressor gene mutated in human lobular breast cancers. EMBO J. 1995;14(24):6107-15.

223. Hajra KM, Chen DY, Fearon ER. The SLUG zinc-finger protein represses Ecadherin in breast cancer. Cancer Res. 2002;62(6):1613-8.

224. Dong C, Yuan T, Wu Y, Wang Y, Fan TW, Miriyala S, Lin Y, Yao J, Shi J, Kang $T$, et al. Loss of FBP1 by snail-mediated repression provides metabolic advantages in basal-like breast cancer. Cancer Cell. 2013;23(3):316-31.

225. Milovanovic T, Planutis K, Nguyen A, Marsh JL, Lin F, Hope C, Holcombe RF. Expression of Wnt genes and frizzled 1 and 2 receptors in normal breast epithelium and infiltrating breast carcinoma. Int J Oncol. 2004;25(5):1337-42.

226. Zhang H, Zhang X, Wu X, Li W, Su P, Cheng H, Xiang L, Gao P, Zhou G. Interference of frizzled 1 (FZD1) reverses multidrug resistance in breast cancer cells through the Wnt/beta-catenin pathway. Cancer Lett. 2012;323(1):106-13.

227. Corda G, Sala G, Lattanzio R, lezzi M, Sallese M, Fragassi G, Lamolinara A, Mirza $H$, Barcaroli D, Ermler S, et al. Functional and prognostic significance of the genomic amplification of frizzled 6 (FZD6) in breast cancer. J Pathol. 2017;241(3):350-61.

228. Chakrabarti R, Wei Y, Hwang J, Hang X, Andres Blanco M, Choudhury A, Tiede B, Romano RA, DeCoste C, Mercatali L, et al. DeltaNp63 promotes stem cell activity in mammary gland development and basal-like breast cancer by enhancing Fzd7 expression and Wnt signalling. Nat Cell Biol. 2014;16(10):1004-15 1001-1013.

229. Yang L, Wu X, Wang Y, Zhang K, Wu J, Yuan YC, Deng X, Chen L, Kim CC, Lau $S$, et al. FZD7 has a critical role in cell proliferation in triple negative breast cancer. Oncogene. 2011;30(43):4437-46.

230. Dey N, Young B, Abramovitz M, Bouzyk M, Barwick B, De P, Leyland-Jones B. Differential activation of Wnt-beta-catenin pathway in triple negative breast cancer increases MMP7 in a PTEN dependent manner. PLoS One. 2013;8(10): e77425.

231. Conway K, Edmiston SN, May R, Kuan PF, Chu H, Bryant C, Tse CK, SwiftScanlan T, Geradts J, Troester MA, et al. DNA methylation profiling in the Carolina breast Cancer study defines cancer subclasses differing in clinicopathologic characteristics and survival. Breast Cancer Res. 2014;16(5):450.

232. Liu CC, Prior J, Piwnica-Worms D, Bu G. LRP6 overexpression defines a class of breast cancer subtype and is a target for therapy. Proc Natl Acad Sci U S A. 2010;107(11):5136-41.

233. Hou MF, Chen PM, Chu PY. LGR5 overexpression confers poor relapse-free survival in breast cancer patients. BMC Cancer. 2018;18(1):219.

234. Yang L, Tang H, Kong Y, Xie X, Chen J, Song C, Liu X, Ye F, Li N, Wang N, et al. LGR5 promotes breast Cancer progression and maintains stem-like cells through activation of Wnt/beta-catenin signaling. Stem Cells. 2015; 33(10):2913-24.

235. Krijgsman O, Roepman P, Zwart W, Carroll JS, Tian S, de Snoo FA, Bender RA, Bernards R, Glas AM. A diagnostic gene profile for molecular subtyping of breast cancer associated with treatment response. Breast Cancer Res Treat. 2012;133(1):37-47.

236. Zhang S, Chen L, Cui B, Chuang HY, Yu J, Wang-Rodriguez J, Tang L, Chen G, Basak GW, Kipps TJ. ROR1 is expressed in human breast cancer and associated with enhanced tumor-cell growth. PLoS One. 2012;7(3):e31127.

237. Cui B, Zhang S, Chen L, Yu J, Widhopf GF 2nd, Fecteau JF, Rassenti LZ, Kipps TJ. Targeting ROR1 inhibits epithelial-mesenchymal transition and metastasis. Cancer Res. 2013;73(12):3649-60.

238. Chien HP, Ueng SH, Chen SC, Chang YS, Lin YC, Lo YF, Chang HK, Chuang WY, Huang YT, Cheung YC, et al. Expression of ROR1 has prognostic significance in triple negative breast cancer. Virchows Arch. 2016;468(5):589-95.

239. Cao J, Wang X, Dai T, Wu Y, Zhang M, Cao R, Zhang R, Wang G, Jiang R, Zhou $B P$, et al. Twist promotes tumor metastasis in basal-like breast cancer by transcriptionally upregulating ROR1. Theranostics. 2018;8(10):2739-51.

240. Balakrishnan A, Goodpaster T, Randolph-Habecker J, Hoffstrom BG, Jalikis FG, Koch LK, Berger C, Kosasih PL, Rajan A, Sommermeyer D, et al. Analysis of ROR1 protein expression in human Cancer and Normal tissues. Clin Cancer Res. 2017;23(12):3061-71.

241. Henry C, Quadir A, Hawkins NJ, Jary E, Llamosas E, Kumar D, Daniels B, Ward $\mathrm{RL}$, Ford CE. Expression of the novel Wnt receptor ROR2 is increased in breast cancer and may regulate both beta-catenin dependent and independent Wnt signalling. J Cancer Res Clin Oncol. 2015;141(2):243-54.
242. Ataseven B, Angerer R, Kates R, Gunesch A, Knyazev P, Hogel B, Becker C, Eiermann W, Harbeck N. PTK7 expression in triple-negative breast cancer. Anticancer Res. 2013;33(9):3759-63.

243. Gartner S, Gunesch A, Knyazeva T, Wolf P, Hogel B, Eiermann W, Ullrich A, Knyazev $P$, Ataseven B. PTK 7 is a transforming gene and prognostic marker for breast cancer and nodal metastasis involvement. PLoS One. 2014;9(1):e84472.

244. Damelin M, Bankovich A, Bernstein J, Lucas J, Chen L, Williams S, Park A, Aguilar J, Ernstoff E, Charati M, et al. A PTK7-targeted antibody-drug conjugate reduces tumor-initiating cells and induces sustained tumor regressions. Sci Transl Med. 2017;9:372.

245. Barbareschi M, Maisonneuve P, Aldovini D, Cangi MG, Pecciarini L, Angelo Mauri F, Veronese S, Caffo O, Lucenti A, Palma PD, et al. High syndecan-1 expression in breast carcinoma is related to an aggressive phenotype and to poorer prognosis. Cancer. 2003;98(3):474-83.

246. Alexander CM, Reichsman F, Hinkes MT, Lincecum J, Becker KA, Cumberledge S, Bernfield M. Syndecan-1 is required for Wnt-1-induced mammary tumorigenesis in mice. Nat Genet. 2000;25(3):329-32.

247. Maeda T, Alexander CM, Friedl A. Induction of syndecan-1 expression in stromal fibroblasts promotes proliferation of human breast cancer cells. Cancer Res. 2004;64(2):612-21.

248. Ibrahim SA, Gadalla R, El-Ghonaimy EA, Samir O, Mohamed HT, Hassan H, Greve B, El-Shinawi M, Mohamed MM, Gotte M. Syndecan-1 is a novel molecular marker for triple negative inflammatory breast cancer and modulates the cancer stem cell phenotype via the IL-6/STAT3, notch and EGFR signaling pathways. Mol Cancer. 2017;16(1):57.

249. Xiang YY, Ladeda V, Filmus J. Glypican-3 expression is silenced in human breast cancer. Oncogene. 2001;20(50):7408-12.

250. McAndrew D, Grice DM, Peters AA, Davis FM, Stewart T, Rice M, Smart CE, Brown MA, Kenny PA, Roberts-Thomson SJ, et al. ORAl1-mediated calcium influx in lactation and in breast cancer. Mol Cancer Ther. 2011;10(3):448-60.

251. Motiani RK, Abdullaev IF, Trebak M. A novel native store-operated calcium channel encoded by Orai3: selective requirement of Orai3 versus Orai1 in estrogen receptor-positive versus estrogen receptor-negative breast cancer cells. J Biol Chem. 2010;285(25):19173-83.

252. Faouzi M, Hague F, Potier M, Ahidouch A, Sevestre H, Ouadid-Ahidouch H. Down-regulation of Orai3 arrests cell-cycle progression and induces apoptosis in breast cancer cells but not in normal breast epithelial cells. J Cell Physiol. 2011;226(2):542-51.

253. Faouzi M, Kischel P, Hague F, Ahidouch A, Benzerdjeb N, Sevestre H, Penner $\mathrm{R}$, Ouadid-Ahidouch $\mathrm{H}$. ORAl3 silencing alters cell proliferation and cell cycle progression via c-myc pathway in breast cancer cells. Biochim Biophys Acta. 2013;1833(3):752-60.

254. Brunquell C, Biliran H, Jennings S, Ireland SK, Chen R, Ruoslahti E. TLE1 is an anoikis regulator and is downregulated by Bit1 in breast cancer cells. Mol Cancer Res. 2012;10(11):1482-95.

255. Di LJ, Byun JS, Wong MM, Wakano C, Taylor T, Bilke S, Baek S, Hunter K, Yang $\mathrm{H}$, Lee $\mathrm{M}$, et al. Genome-wide profiles of CtBP link metabolism with genome stability and epithelial reprogramming in breast cancer. Nat Commun. 2013:4:1449.

256. Geyer FC, Lacroix-Triki M, Savage K, Arnedos M, Lambros MB, MacKay A, Natrajan R. Reis-Filho JS: beta-catenin pathway activation in breast cancer is associated with triple-negative phenotype but not with CTNNB1 mutation. Mod Pathol. 2011;24(2):209-31.

257. Khramtsov Al, Khramtsova GF, Tretiakova M, Huo D, Olopade Ol, Goss KH. Wnt/beta-catenin pathway activation is enriched in basal-like breast cancers and predicts poor outcome. Am J Pathol. 2010;176(6):2911-20.

258. Sarrio D, Moreno-Bueno G, Hardisson D, Sanchez-Estevez C, Guo M, Herman JG, Gamallo C, Esteller M, Palacios J. Epigenetic and genetic alterations of APC and $\mathrm{CDH1}$ genes in lobular breast cancer: relationships with abnormal E-cadherin and catenin expression and microsatellite instability. Int J Cancer. 2003;106(2):208-15.

259. Mukherjee N, Bhattacharya N, Alam N, Roy A, Roychoudhury S, Panda CK. Subtype-specific alterations of the Wht signaling pathway in breast cancer: clinical and prognostic significance. Cancer Sci. 2012;103(2):210-20.

260. Prasad CP, Mirza S, Sharma G, Prashad R, DattaGupta S, Rath G, Ralhan R. Epigenetic alterations of $\mathrm{CDH} 1$ and $\mathrm{APC}$ genes: relationship with activation of Wnt/beta-catenin pathway in invasive ductal carcinoma of breast. Life Sci. 2008;83(9-10):318-25.

261. Furuuchi K, Tada M, Yamada H, Kataoka A, Furuuchi N, Hamada J, Takahashi M, Todo S, Moriuchi T. Somatic mutations of the APC gene in primary breast cancers. Am J Pathol. 2000:156(6):1997-2005. 
262. Van der Auwera I, Van Laere SJ, Van den Bosch SM, Van den Eynden GG, Trinh BX, van Dam PA, Colpaert CG, van Engeland M, Van Marck EA Vermeulen PB, et al. Aberrant methylation of the adenomatous polyposis coli (APC) gene promoter is associated with the inflammatory breast cancer phenotype. Br J Cancer. 2008;99(10):1735-42.

263. Janghorban M, Farrell AS, Allen-Petersen BL, Pelz C, Daniel CJ, Oddo J, Langer EM, Christensen DJ, Sears RC. Targeting c-MYC by antagonizing PP2A inhibitors in breast cancer. Proc Natl Acad Sci U S A. 2014;111(25):9157-62.

264. Zhang YY, Wang QM, Niu HL, Liu X, Zhang QL. The general expression analysis of WTX gene in Normal and Cancer tissues. Pathol Oncol Res. 2017; 23(2):439-46.

265. Webster MT, Rozycka M, Sara E, Davis E, Smalley M, Young N, Dale TC, Wooster R. Sequence variants of the axin gene in breast, colon, and other cancers: an analysis of mutations that interfere with GSK3 binding. Genes Chromosomes Cancer. 2000;28(4):443-53.

266. Gelmini S, Poggesi M, Distante V, Bianchi S, Simi L, Luconi M, Raggi CC, Cataliotti L, Pazzagli M, Orlando C. Tankyrase, a positive regulator of telomere elongation, is over expressed in human breast cancer. Cancer Lett. 2004;216(1):81-7.

267. Schnelzer A, Prechtel D, Knaus U, Dehne K, Gerhard M, Graeff H, Harbeck N, Schmitt M, Lengyel E. Rac1 in human breast cancer: overexpression, mutation analysis, and characterization of a new isoform, Rac1b. Oncogene. 2000;19(26):3013-20.

268. Nguyen A, Rosner A, Milovanovic T, Hope C, Planutis K, Saha B, Chaiwun B, Lin F, Imam SA, Marsh JL, et al. Wht pathway component LEF1 mediates tumor cell invasion and is expressed in human and murine breast cancers lacking ErbB2 (her-2/neu) overexpression. Int J Oncol. 2005;27(4):949-56.

269. Xiao XS, Cai MY, Chen JW, Guan XY, Kung HF, Zeng YX, Xie D. High expression of p300 in human breast Cancer correlates with tumor recurrence and predicts adverse prognosis. Chin J Cancer Res. 2011;23(3):201-7.

270. Andrews PG, Lake BB, Popadiuk C, Kao KR. Requirement of Pygopus 2 in breast cancer. Int J Oncol. 2007;30(2):357-63.

271. Elsarraj HS, Hong Y, Valdez KE, Michaels W, Hook M, Smith WP, Chien J, Herschkowitz Jl, Troester MA, Beck M, et al. Expression profiling of in vivo ductal carcinoma in situ progression models identified B cell lymphoma-9 as a molecular driver of breast cancer invasion. Breast Cancer Res. 2015;17:128.

272. Harbeck N, Penault-Llorca F, Cortes J, Gnant M, Houssami N, Poortmans P, Ruddy K, Tsang J, Cardoso F. Breast cancer. Nat Rev Dis Primers. 2019;5(1):66.

273. Hashizume R, Koizumi H, Ihara A, Ohta T, Uchikoshi T. Expression of betacatenin in normal breast tissue and breast carcinoma: a comparative study with epithelial cadherin and alpha-catenin. Histopathology. 1996;29(2):139-46.

274. De Leeuw WJ, Berx G, Vos CB, Peterse JL, Van de Vijver MJ, Litvinov S, Van Roy F, Cornelisse CJ, Cleton-Jansen AM. Simultaneous loss of E-cadherin and catenins in invasive lobular breast cancer and lobular carcinoma in situ. J Pathol. 1997;183(4):404-11.

275. Sinha PS, Bendall S, Bates T. Does routine grading of invasive lobular cancer of the breast have the same prognostic significance as for ductal cancers? Eur J Surg Oncol. 2000;26(8):733-7.

276. Perou CM, Sorlie T, Eisen MB, van de Rijn M, Jeffrey SS, Rees CA, Pollack JR, Ross DT, Johnsen H, Akslen LA, et al. Molecular portraits of human breast tumours. Nature. 2000;406(6797):747-52.

277. Sorlie T, Perou CM, Tibshirani R, Aas T, Geisler S, Johnsen H, Hastie T, Eisen $M B$, van de Rijn $M$, Jeffrey SS, et al. Gene expression patterns of breast carcinomas distinguish tumor subclasses with clinical implications. Proc Nat Acad Sci U S A. 2001;98(19):10869-74.

278. Sorlie T, Tibshirani R, Parker J, Hastie T, Marron JS, Nobel A, Deng S, Johnsen $H$, Pesich R, Geisler S, et al. Repeated observation of breast tumor subtypes in independent gene expression data sets. Proc Natl Acad Sci U S A. 2003; 100(14):8418-23.

279. Peppercorn J, Perou CM, Carey LA. Molecular subtypes in breast cancer evaluation and management: divide and conquer. Cancer Investig. 2008 26(1):1-10.

280. Herschkowitz JI, Simin K, Weigman VJ, Mikaelian I, Usary J, Hu Z, Rasmussen

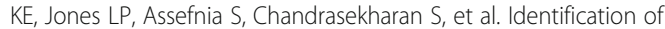
conserved gene expression features between murine mammary carcinoma models and human breast tumors. Genome Biol. 2007;8(5):R76.

281. Prat A, Parker JS, Karginova O, Fan C, Livasy C, Herschkowitz Jl, He X, Perou CM. Phenotypic and molecular characterization of the claudin-low intrinsic subtype of breast cancer. Breast Cancer Res. 2010;12(5):R68.

282. Fougner $\mathrm{C}$, Bergholtz $\mathrm{H}$, Norum JH, Sorlie T. Re-definition of claudin-low as a breast cancer phenotype. Nat Commun. 2020;11(1):1787.
283. Voduc KD, Cheang MC, Tyldesley S, Gelmon K, Nielsen TO, Kennecke H. Breast cancer subtypes and the risk of local and regional relapse. J Clin Oncol. 2010;28(10):1684-91.

284. Foulkes WD, Smith IE, Reis-Filho JS. Triple-negative breast cancer. N Engl J Med. 2010;363(20):1938-48.

285. Lehmann BD, Bauer JA, Chen X, Sanders ME, Chakravarthy AB, Shyr $Y$, Pietenpol JA. Identification of human triple-negative breast cancer subtypes and preclinical models for selection of targeted therapies. J Clin Invest. 2011;121(7):2750-67.

286. Lehmann BD, Pietenpol JA. Identification and use of biomarkers in treatment strategies for triple-negative breast cancer subtypes. J Pathol. 2014;232(2):142-50.

287. Hayes MJ, Thomas D, Emmons A, Giordano TJ, Kleer CG. Genetic changes of Wnt pathway genes are common events in metaplastic carcinomas of the breast. Clin Cancer Res. 2008;14(13):4038-44.

288. Li Y, Welm B, Podsypanina K, Huang S, Chamorro M, Zhang X, Rowlands T, Egeblad M, Cowin P, Werb Z, et al. Evidence that transgenes encoding components of the Wnt signaling pathway preferentially induce mammary cancers from progenitor cells. Proc Natl Acad Sci U S A. 2003: 100(26):15853-8.

289. Reis ES, Mastellos DC, Ricklin D, Mantovani A, Lambris JD. Complement in cancer: untangling an intricate relationship. Nat Rev Immunol. 2018;18(1):5-18.

290. Yarchoan M, Johnson BA 3rd, Lutz ER, Laheru DA, Jaffee EM. Targeting neoantigens to augment antitumour immunity. Nat Rev Cancer. 2017;17(4): 209-22.

291. Zhang X, Kim S, Hundal J, Herndon JM, Li S, Petti AA, Soysal SD, Li L, McLellan MD, Hoog J, et al. Breast Cancer Neoantigens can induce CD8(+) T-cell responses and antitumor immunity. Cancer Immunol Res. 2017;5(7): 516-23.

292. Ahmadzadeh M, Pasetto A, Jia L, Deniger DC, Stevanovic S, Robbins PF, Rosenberg SA. Tumor-infiltrating human CD4(+) regulatory $T$ cells display a distinct TCR repertoire and exhibit tumor and neoantigen reactivity. Sci Immunol. 2019;4:31.

293. Blanco P, Pitard V, Viallard JF, Taupin JL, Pellegrin JL, Moreau JF. Increase in activated CD8+ T lymphocytes expressing perforin and granzyme B correlates with disease activity in patients with systemic lupus erythematosus. Arthritis Rheum. 2005;52(1):201-11.

294. Janssen EM, Droin NM, Lemmens EE, Pinkoski MJ, Bensinger SJ, Ehst BD, Griffith TS, Green DR, Schoenberger SP. CD4+ T-cell help controls CD8+ Tcell memory via TRAlL-mediated activation-induced cell death. Nature. 2005; 434(7029):88-93.

295. Mahmoud SM, Paish EC, Powe DG, Macmillan RD, Grainge MJ, Lee AH, Ellis IO, Green AR. Tumor-infiltrating CD8+ lymphocytes predict clinical outcome in breast cancer. J Clin Oncol. 2011;29(15):1949-55.

296. Macatonia SE, Hsieh CS, Murphy KM, O'Garra A. Dendritic cells and macrophages are required for Th1 development of CD4+ T cells from alpha beta TCR transgenic mice: IL-12 substitution for macrophages to stimulate IFN-gamma production is IFN-gamma-dependent. Int Immunol. 1993;5(9): 1119-28.

297. Hix LM, Shi YH, Brutkiewicz RR, Stein PL, Wang CR, Zhang M. CD1dexpressing breast cancer cells modulate NKT cell-mediated antitumor immunity in a murine model of breast cancer metastasis. PLoS One. 2011; 6(6):e20702.

298. Spranger S, Bao R, Gajewski TF. Melanoma-intrinsic beta-catenin signalling prevents anti-tumour immunity. Nature. 2015;523(7559):231-5.

299. Barkal AA, Brewer RE, Markovic M, Kowarsky M, Barkal SA, Zaro BW, Krishnan $\checkmark$, Hatakeyama J, Dorigo O, Barkal LJ, et al. CD24 signalling through macrophage Siglec-10 is a target for cancer immunotherapy. Nature. 2019; 572(7769):392-6.

300. Oldenborg PA, Zheleznyak A, Fang YF, Lagenaur CF, Gresham HD, Lindberg FP. Role of CD47 as a marker of self on red blood cells. Science. 2000; 288(5473):2051-4

301. Blazar BR, Lindberg FP, Ingulli E, Panoskaltsis-Mortari A, Oldenborg PA, lizuka K, Yokoyama WM, Taylor PA. CD47 (integrin-associated protein) engagement of dendritic cell and macrophage counterreceptors is required to prevent the clearance of donor lymphohematopoietic cells. J Exp Med. 2001;194(4):541-9.

302. Betancur PA, Abraham BJ, Yiu YY, Willingham SB, Khameneh F, Zarnegar M, Kuo AH, McKenna K, Kojima Y, Leeper NJ, et al. A CD47-associated superenhancer links pro-inflammatory signalling to CD47 upregulation in breast cancer. Nat Commun. 2017:8:14802 
303. Shulewitz M, Soloviev I, Wu T, Koeppen H, Polakis P, Sakanaka C. Repressor roles for TCF-4 and Sfrp1 in Wnt signaling in breast cancer. Oncogene. 2006;25(31):4361-9.

304. Noman MZ, Van Moer K, Marani V, Gemmill RM, Tranchevent LC, Azuaje F, Muller A, Chouaib S, Thiery JP, Berchem G, et al. CD47 is a direct target of SNAI1 and ZEB1 and its blockade activates the phagocytosis of breast cancer cells undergoing EMT. Oncoimmunology. 2018;7(4):e1345415.

305. Casey SC, Tong L, Li Y, Do R, Walz S, Fitzgerald KN, Gouw AM, Baylot V, Gutgemann I, Eilers M, et al. MYC regulates the antitumor immune response through CD47 and PD-L1. Science. 2016;352(6282):227-31.

306. Castagnoli L, Cancila V, Cordoba-Romero SL, Faraci S, Talarico G, Belmonte B, lorio MV, Milani M, Volpari T, Chiodoni C, et al. WNT signaling modulates PD-L1 expression in the stem cell compartment of triple-negative breast cancer. Oncogene. 2019;38(21):4047-60.

307. Shah KV, Chien AJ, Yee C, Moon RT. CTLA-4 is a direct target of Wnt/betacatenin signaling and is expressed in human melanoma tumors. J Invest Dermatol. 2008;128(12):2870-9.

308. DeNardo DG, Brennan DJ, Rexhepaj E, Ruffell B, Shiao SL, Madden SF, Gallagher WM, Wadhwani N, Keil SD, Junaid SA, et al. Leukocyte complexity predicts breast cancer survival and functionally regulates response to chemotherapy. Cancer Discov. 2011;1(1):54-67.

309. Mahmoud SM, Paish EC, Powe DG, Macmillan RD, Lee AH, Ellis 1O, Green AR. An evaluation of the clinical significance of FOXP3+ infiltrating cells in human breast cancer. Breast Cancer Res Treat. 2011;127(1):99-108.

310. Liu F, Lang R, Zhao J, Zhang X, Pringle GA, Fan Y, Yin D, Gu F, Yao Z, Fu L. CD8(+) cytotoxic T cell and FOXP3(+) regulatory $T$ cell infiltration in relation to breast cancer survival and molecular subtypes. Breast Cancer Res Treat. 2011;130(2):645-55.

311. Liu F, Li Y, Ren M, Zhang X, Guo X, Lang R, Gu F, Fu L. Peritumoral FOXP3(+) regulatory $T$ cell is sensitive to chemotherapy while intratumoral FOXP3(+) regulatory $T$ cell is prognostic predictor of breast cancer patients. Breast Cancer Res Treat. 2012;135(2):459-67.

312. Wagner J, Rapsomaniki MA, Chevrier S, Anzeneder T, Langwieder C, Dykgers A, Rees M, Ramaswamy A, Muenst S, Soysal SD, et al. A single-cell atlas of the tumor and immune ecosystem of human breast Cancer. Cell. 2019; 177(5):1330-45 e1318.

313. Cassetta L, Pollard JW. Targeting macrophages: therapeutic approaches in cancer. Nat Rev Drug Discov. 2018;17(12):887-904.

314. Togashi Y, Shitara K, Nishikawa H. Regulatory T cells in cancer immunosuppression - implications for anticancer therapy. Nat Rev Clin Oncol. 2019;16(6):356-71.

315. Narayan P, Wahby S, Gao JJ, Amiri-Kordestani L, Ibrahim A, Bloomquist E, Tang S, Xu Y, Liu J, Fu W, et al. FDA approval summary: Atezolizumab plus paclitaxel protein-bound for the treatment of patients with advanced or metastatic TNBC whose tumors express PD-L1. Clin Cancer Res. 2020;26(10): 2284-9.

316. Bertucci F, Ng CKY, Patsouris A, Droin N, Piscuoglio S, Carbuccia N, Soria JC, Dien AT, Adnani Y, Kamal M, et al. Genomic characterization of metastatic breast cancers. Nature. 2019;569(7757):560-4.

317. Coffelt SB, Kersten K, Doornebal CW, Weiden J, Vrijland K, Hau CS, Verstegen NJM, Ciampricotti $M$, Hawinkels $L$, Jonkers J, et al. IL-17-producing gammadelta T cells and neutrophils conspire to promote breast cancer metastasis. Nature. 2015;522(7556):345-8.

318. Tan W, Zhang W, Strasner A, Grivennikov S, Cheng JQ, Hoffman RM, Karin $M$. Tumour-infiltrating regulatory $T$ cells stimulate mammary cancer metastasis through RANKL-RANK signalling. Nature. 2011;470(7335):548-53.

319. Kato T, Noma K, Ohara T, Kashima H, Katsura Y, Sato H, Komoto S, Katsube R, Ninomiya T, Tazawa $H$, et al. Cancer-associated fibroblasts affect Intratumoral CD8(+) and FoxP3(+) T cells via IL6 in the tumor microenvironment. Clin Cancer Res. 2018;24(19):4820-33.

320. DiMeo TA, Anderson K, Phadke P, Fan C, Perou CM, Naber S, Kuperwasser C. A novel lung metastasis signature links Wnt signaling with cancer cell selfrenewal and epithelial-mesenchymal transition in basal-like breast cancer. Cancer Res. 2009;69(13):5364-73.

321. Wu ZQ, Li XY, Hu CY, Ford M, Kleer CG, Weiss SJ. Canonical Wnt signaling regulates slug activity and links epithelial-mesenchymal transition with epigenetic breast Cancer 1, early onset (BRCA1) repression. Proc Natl Acad Sci U S A. 2012;109(41):16654-9.

322. Yook JI, Li XY, Ota I, Hu C, Kim HS, Kim NH, Cha SY, Ryu JK, Choi YJ, Kim J, et al. A Wnt-Axin2-GSK3beta cascade regulates Snail1 activity in breast cancer cells. Nat Cell Biol. 2006;8(12):1398-406.
323. Schmalhofer O, Brabletz S, Brabletz T. E-cadherin, beta-catenin, and ZEB1 in malignant progression of cancer. Cancer Metastasis Rev. 2009;28(1-2):151-66.

324. Zhao Z, Lu P, Zhang H, Xu H, Gao N, Li M, Liu C. Nestin positively regulates the Wnt/beta-catenin pathway and the proliferation, survival and invasiveness of breast cancer stem cells. Breast Cancer Res. 2014;16(4):408.

325. Balestrieri E, Argaw-Denboba A, Gambacurta A, Cipriani C, Bei R, Serafino A, Sinibaldi-Vallebona $P$, Matteucci C. Human endogenous retrovirus $K$ in the crosstalk between Cancer cells microenvironment and plasticity: a new perspective for combination therapy. Front Microbiol. 2018;9:1448.

326. Sarrio D, Rodriguez-Pinilla SM, Hardisson D, Cano A, Moreno-Bueno G, Palacios J. Epithelial-mesenchymal transition in breast cancer relates to the basal-like phenotype. Cancer Res. 2008;68(4):989-97.

327. Polyak K, Weinberg RA. Transitions between epithelial and mesenchymal states: acquisition of malignant and stem cell traits. Nat Rev Cancer. 2009; 9(4):265-73.

328. Yang J, Antin P, Berx G, Blanpain C, Brabletz T, Bronner M, Campbell K, Cano A, Casanova J, Christofori G, et al. Guidelines and definitions for research on epithelial-mesenchymal transition. Nat Rev Mol Cell Biol. 2020;21(6):341-52.

329. Lamouille S, Xu J, Derynck R. Molecular mechanisms of epithelialmesenchymal transition. Nat Rev Mol Cell Biol. 2014;15(3):178-96.

330. Come C, Magnino F, Bibeau F, De Santa BP, Becker KF, Theillet C, Savagner P. Snail and slug play distinct roles during breast carcinoma progression. Clin Cancer Res. 2006;12(18):5395-402.

331. Zhou BP, Deng J, Xia W, Xu J, Li YM, Gunduz M, Hung MC. Dual regulation of snail by GSK-3beta-mediated phosphorylation in control of epithelialmesenchymal transition. Nat Cell Biol. 2004;6(10):931-40.

332. Martin TA, Goyal A, Watkins G, Jiang WG. Expression of the transcription factors snail, slug, and twist and their clinical significance in human breast cancer. Ann Surg Oncol. 2005;12(6):488-96.

333. Karihtala P, Auvinen P, Kauppila S, Haapasaari KM, Jukkola-Vuorinen A, Soini Y. Vimentin, zeb1 and Sip1 are up-regulated in triple-negative and basal-like breast cancers: association with an aggressive tumour phenotype. Breast Cancer Res Treat. 2013;138(1):81-90.

334. Proia TA, Keller PJ, Gupta PB, Klebba I, Jones AD, Sedic M, Gilmore H, Tung N, Naber SP, Schnitt S, et al. Genetic predisposition directs breast cancer phenotype by dictating progenitor cell fate. Cell Stem Cell. 2011;8(2):149-63.

335. Howe LR, Watanabe O, Leonard J, Brown AM. Twist is up-regulated in response to Wnt1 and inhibits mouse mammary cell differentiation. Cancer Res. 2003;63(8):1906-13.

336. Wang Y, Bu F, Royer C, Serres S, Larkin JR, Soto MS, Sibson NR, Salter V, Fritzsche F, Turnquist $C$, et al. ASPP2 controls epithelial plasticity and inhibits metastasis through beta-catenin-dependent regulation of ZEB1. Nat Cell Biol. 2014;16(11):1092-104.

337. Miquelajauregui A, Van de Putte T, Polyakov A, Nityanandam A, Boppana S, Seuntjens E, Karabinos A, Higashi Y, Huylebroeck D, Tarabykin V. Smadinteracting protein-1 (Zfh $\times 1$ b) acts upstream of Wht signaling in the mouse hippocampus and controls its formation. Proc Natl Acad Sci U S A. 2007; 104(31):12919-24.

338. Zhou DD, Wang X, Wang Y, Xiang XJ, Liang ZC, Zhou Y, Xu A, Bi CH, Zhang L. MicroRNA-145 inhibits hepatic stellate cell activation and proliferation by targeting ZEB2 through Wnt/beta-catenin pathway. Mol Immunol. 2016;75: 151-60.

339. Thiery JP, Sleeman JP. Complex networks orchestrate epithelialmesenchymal transitions. Nat Rev Mol Cell Biol. 2006;7(2):131-42.

340. Dongre A, Weinberg RA. New insights into the mechanisms of epithelialmesenchymal transition and implications for cancer. Nat Rev Mol Cell Biol. 2019;20(2):69-84.

341. Yang J, Mani SA, Donaher JL, Ramaswamy S, Itzykson RA, Come C, Savagner P, Gitelman I, Richardson A, Weinberg RA. Twist, a master regulator of morphogenesis, plays an essential role in tumor metastasis. Cell. 2004;117(7): 927-39.

342. Dong C, Wu Y, Yao J, Wang Y, Yu Y, Rychahou PG, Evers BM, Zhou BP. G9a interacts with snail and is critical for snail-mediated E-cadherin repression in human breast cancer. J Clin Invest. 2012;122(4):1469-86.

343. Fischer KR, Durrans A, Lee S, Sheng J, Li F, Wong ST, Choi H, El Rayes T, Ryu $\mathrm{S}$, Troeger J, et al. Epithelial-to-mesenchymal transition is not required for lung metastasis but contributes to chemoresistance. Nature. 2015;527(7579): 472-6.

344. Mani SA, Guo W, Liao MJ, Eaton EN, Ayyanan A, Zhou AY, Brooks M, Reinhard F, Zhang CC, Shipitsin M, et al. The epithelial-mesenchymal transition generates cells with properties of stem cells. Cell. 2008;133(4):704-15. 
345. Thiery JP, Acloque H, Huang RY, Nieto MA. Epithelial-mesenchymal transitions in development and disease. Cell. 2009;139(5):871-90.

346. Jackson HW, Fischer JR, Zanotelli VRT, Ali HR, Mechera R, Soysal SD, Moch H, Muenst S, Varga Z, Weber WP, et al. The single-cell pathology landscape of breast cancer. Nature. 2020;578(7796):615-20.

347. Bedard PL, Hansen AR, Ratain MJ, Siu LL. Tumour heterogeneity in the clinic. Nature. 2013;501(7467):355-64.

348. Prasetyanti PR, Medema JP. Intra-tumor heterogeneity from a cancer stem cell perspective. Mol Cancer. 2017;16(1):41.

349. Fu NY, Nolan E, Lindeman GJ, Visvader JE. Stem cells and the differentiation hierarchy in mammary gland development. Physiol Rev. 2020;100(2):489-523.

350. Fu NY, Rios AC, Pal B, Law CW, Jamieson P, Liu R, Vaillant F, Jackling F, Liu $\mathrm{KH}$, Smyth GK, et al. Identification of quiescent and spatially restricted mammary stem cells that are hormone responsive. Nat Cell Biol. 2017;19(3): $164-76$.

351. Lloyd-Lewis B, Harris OB, Watson CJ, Davis FM. Mammary stem cells: premise, properties, and perspectives. Trends Cell Biol. 2017;27(8):556-67.

352. Li L, Clevers H. Coexistence of quiescent and active adult stem cells in mammals. Science. 2010;327(5965):542-5.

353. Shackleton M, Vaillant F, Simpson KJ, Stingl J, Smyth GK, Asselin-Labat ML, Wu L, Lindeman GJ, Visvader JE. Generation of a functional mammary gland from a single stem cell. Nature. 2006;439(7072):84-8.

354. Wang D, Cai C, Dong X, Yu QC, Zhang XO, Yang L, Zeng YA. Identification of multipotent mammary stem cells by protein $C$ receptor expression. Nature. 2015;517(7532):81-4.

355. Barker N, van Es JH, Kuipers J, Kujala P, van den Born M, Cozijnsen M, Haegebarth A, Korving J, Begthel H, Peters PJ, et al. Identification of stem cells in small intestine and colon by marker gene Lgr5. Nature. 2007; 449(7165):1003-7.

356. de Visser KE, Ciampricotti M, Michalak EM, Tan DW, Speksnijder EN, Hau CS, Clevers H, Barker N, Jonkers J. Developmental stage-specific contribution of LGR5(+) cells to basal and luminal epithelial lineages in the postnatal mammary gland. J Pathol. 2012;228(3):300-9.

357. Zeng YA, Nusse R. Wht proteins are self-renewal factors for mammary stem cells and promote their long-term expansion in culture. Cell Stem Cell. 2010;6(6):568-77.

358. van Amerongen R, Bowman AN, Nusse R. Developmental stage and time dictate the fate of Wnt/beta-catenin-responsive stem cells in the mammary gland. Cell Stem Cell. 2012;11(3):387-400.

359. Zhao C, Cai S, Shin K, Lim A, Kalisky T, Lu WJ, Clarke MF, Beachy PA. Stromal Gli2 activity coordinates a niche signaling program for mammary epithelial stem cells. Science. 2017;356:6335.

360. Chakrabarti R, Celia-Terrassa T, Kumar S, Hang X, Wei Y, Choudhury A, Hwang J, Peng J, Nixon B, Grady JJ, et al. Notch ligand Dll1 mediates crosstalk between mammary stem cells and the macrophageal niche. Science. 2018:360:6396.

361. Lim E, Vaillant F, Wu D, Forrest NC, Pal B, Hart AH, Asselin-Labat ML, Gyorki DE, Ward T, Partanen A, et al. Aberrant luminal progenitors as the candidate target population for basal tumor development in BRCA1 mutation carriers. Nat Med. 2009;15(8):907-13.

362. Shehata M, Teschendorff A, Sharp G, Novcic N, Russell IA, Avril S, Prater M, Eirew P, Caldas C, Watson CJ, et al. Phenotypic and functional characterisation of the luminal cell hierarchy of the mammary gland. Breast Cancer Res. 2012;14(5):R134.

363. Stingl J, Caldas C. Molecular heterogeneity of breast carcinomas and the cancer stem cell hypothesis. Nat Rev Cancer. 2007;7(10):791-9.

364. Visvader JE. Cells of origin in cancer. Nature. 2011:469(7330):314-22.

365. Al-Hajj M, Wicha MS, Benito-Hernandez A, Morrison SJ, Clarke MF. Prospective identification of tumorigenic breast cancer cells. Proc Natl Acad Sci U S A. 2003;100(7):3983-8.

366. Ginestier C, Hur MH, Charafe-Jauffret E, Monville F, Dutcher J, Brown M, Jacquemier J, Viens P, Kleer CG, Liu S, et al. ALDH1 is a marker of normal and malignant human mammary stem cells and a predictor of poor clinical outcome. Cell Stem Cell. 2007;1(5):555-67.

367. Liu X, Taftaf R, Kawaguchi M, Chang YF, Chen W, Entenberg D, Zhang Y, Gerratana L, Huang S, Patel DB, et al. Homophilic CD44 interactions mediate tumor cell aggregation and polyclonal metastasis in patient-derived breast Cancer models. Cancer Discov. 2019;9(1):96-113.

368. Liu BY, McDermott SP, Khwaja SS, Alexander CM. The transforming activity of Wnt effectors correlates with their ability to induce the accumulation of mammary progenitor cells. Proc Natl Acad Sci U S A. 2004;101(12):4158-63.
369. Sternlicht MD, Lochter A, Sympson CJ, Huey B, Rougier JP, Gray JW, Pinkel D, Bissell MJ, Werb Z. The stromal proteinase MMP3/stromelysin-1 promotes mammary carcinogenesis. Cell. 1999;98(2):137-46.

370. Vasan N, Baselga J, Hyman DM. A view on drug resistance in cancer. Nature. 2019;575(7782):299-309.

371. Goldie JH, Coldman AJ. A mathematic model for relating the drug sensitivity of tumors to their spontaneous mutation rate. Cancer Treat Rep. 1979;63(11-12):1727-33.

372. Giantonio BJ. Targeted therapies: Goldie-Coldman and bevacizumab beyond disease progression. Nat Rev Clin Oncol. 2009;6(6):311-2.

373. Bai X, Ni J, Beretov J, Graham P, Li Y. Cancer stem cell in breast cancer therapeutic resistance. Cancer Treat Rev. 2018;69:152-63.

374. Sideras K, Ingle JN, Ames MM, Loprinzi CL, Mrazek DP, Black JL, Weinshilboum RM, Hawse JR, Spelsberg TC, Goetz MP. Coprescription of tamoxifen and medications that inhibit CYP2D6. J Clin Oncol. 2010;28(16): 2768-76.

375. Schinkel AH, Jonker JW. Mammalian drug efflux transporters of the ATP binding cassette (ABC) family: an overview. Adv Drug Deliv Rev. 2003;55(1):3-29.

376. Zhang ZM, Wu JF, Luo QC, Liu QF, Wu QW, Ye GD, She HQ, Li BA. Pygo2 activates MDR1 expression and mediates chemoresistance in breast cancer via the Wnt/beta-catenin pathway. Oncogene. 2016;35(36):4787-97.

377. Pinilla SM, Honrado E, Hardisson D, Benitez J, Palacios J. Caveolin-1 expression is associated with a basal-like phenotype in sporadic and hereditary breast cancer. Breast Cancer Res Treat. 2006;99(1):85-90.

378. Savage K, Lambros MB, Robertson D, Jones RL, Jones C, Mackay A, James M, Hornick JL, Pereira EM, Milanezi F, et al. Caveolin 1 is overexpressed and amplified in a subset of basal-like and metaplastic breast carcinomas: a morphologic, ultrastructural, immunohistochemical, and in situ hybridization analysis. Clin Cancer Res. 2007;13(1):90-101.

379. Wang Z, Wang N, Li W, Liu P, Chen Q, Situ H, Zhong S, Guo L, Lin Y, Shen J, et al. Caveolin-1 mediates chemoresistance in breast cancer stem cells via beta-catenin/ABCG2 signaling pathway. Carcinogenesis. 2014;35(10):2346-56.

380. Wang N, Wang Z, Peng C, You J, Shen J, Han S, Chen J. Dietary compound isoliquiritigenin targets GRP78 to chemosensitize breast cancer stem cells via beta-catenin/ABCG2 signaling. Carcinogenesis. 2014;35(11):2544-54.

381. Guan J, Zhou W, Hafner M, Blake RA, Chalouni C, Chen IP, De Bruyn T, Giltnane JM, Hartman SJ, Heidersbach A, et al. Therapeutic ligands antagonize estrogen receptor function by impairing its mobility. Cell. 2019; 178(4):949-63 e918.

382. Musgrove EA, Sutherland RL. Biological determinants of endocrine resistance in breast cancer. Nat Rev Cancer. 2009;9(9):631-43.

383. Hoskins JM, Carey LA, McLeod HL. CYP2D6 and tamoxifen: DNA matters in breast cancer. Nat Rev Cancer. 2009;9(8):576-86.

384. Loh YN, Hedditch EL, Baker LA, Jary E, Ward RL, Ford CE. The Wnt signalling pathway is upregulated in an in vitro model of acquired tamoxifen resistant breast cancer. BMC Cancer. 2013;13:174.

385. Teft WA, Gong IY, Dingle B, Potvin K, Younus J, Vandenberg TA, Brackstone M, Perera FE, Choi YH, Zou G, et al. CYP3A4 and seasonal variation in vitamin D status in addition to CYP2D6 contribute to therapeutic endoxifen level during tamoxifen therapy. Breast Cancer Res Treat. 2013;139(1):95-105.

386. Schmiedlin-Ren P, Thummel KE, Fisher JM, Paine MF, Lown KS, Watkins PB. Expression of enzymatically active CYP3A4 by Caco-2 cells grown on extracellular matrix-coated permeable supports in the presence of 1alpha,25-dihydroxyvitamin D3. Mol Pharmacol. 1997;51(5):741-54.

387. Thummel KE, Brimer C, Yasuda K, Thottassery J, Senn T, Lin Y, Ishizuka H, Kharasch E, Schuetz J, Schuetz E. Transcriptional control of intestinal cytochrome P-4503A by 1alpha,25-dihydroxy vitamin D3. Mol Pharmacol. 2001;60(6):1399-406

388. Zheng W, Duan B, Zhang Q, Ouyang L, Peng W, Qian F, Wang Y, Huang S. Vitamin D-induced vitamin D receptor expression induces tamoxifen sensitivity in MCF-7 stem cells via suppression of Wnt/beta-catenin signaling. Biosci Rep. 2018;38:6.

389. Palmer HG, Gonzalez-Sancho JM, Espada J, Berciano MT, Puig I, Baulida J, Quintanilla M, Cano A, de Herreros AG, Lafarga M, et al. Vitamin D (3) promotes the differentiation of colon carcinoma cells by the induction of $E$ cadherin and the inhibition of beta-catenin signaling. J Cell Biol. 2001; 154(2):369-87

390. Shah S, Hecht A, Pestell R, Byers SW. Trans-repression of beta-catenin activity by nuclear receptors. J Biol Chem. 2003;278(48):48137-45. 
391. Teft WA, Mansell SE, Kim RB. Endoxifen, the active metabolite of tamoxifen, is a substrate of the efflux transporter P-glycoprotein (multidrug resistance 1). Drug Metab Dispos. 2011;39(3):558-62.

392. Adams S, Gatti-Mays ME, Kalinsky K, Korde LA, Sharon E, Amiri-Kordestani L, Bear H, McArthur HL, Frank E, Perlmutter J, et al. Current landscape of immunotherapy in breast Cancer: a review. JAMA Oncol. 2019.

393. Pardoll DM. The blockade of immune checkpoints in cancer immunotherapy. Nat Rev Cancer. 2012;12(4):252-64.

394. Schmid P, Adams S, Rugo HS, Schneeweiss A, Barrios CH, Iwata H, Dieras V, Hegg R, Im SA, Shaw Wright G, et al. Atezolizumab and nab-paclitaxel in advanced triple-negative breast Cancer. N Engl J Med. 2018;379(22):2108-21.

395. Wang B, Tian T, Kalland KH, Ke X, Qu Y. Targeting Wnt/beta-catenin signaling for Cancer immunotherapy. Trends Pharmacol Sci. 2018;39(7):648-58.

396. Hsu JM, Xia W, Hsu YH, Chan LC, Yu WH, Cha JH, Chen CT, Liao HW, Kuo CW, Khoo KH, et al. STT3-dependent PD-L1 accumulation on cancer stem cells promotes immune evasion. Nat Commun. 2018;9(1):1908.

397. Kim IS, Gao Y, Welte T, Wang H, Liu J, Janghorban M, Sheng K, Niu Y, Goldstein A, Zhao N, et al. Immuno-subtyping of breast cancer reveals distinct myeloid cell profiles and immunotherapy resistance mechanisms. Nat Cell Biol. 2019;21(9):1113-26.

398. Proffitt KD, Madan B, Ke Z, Pendharkar V, Ding L, Lee MA, Hannoush RN, Virshup DM. Pharmacological inhibition of the Wnt acyltransferase PORCN prevents growth of WNT-driven mammary cancer. Cancer Res. 2013;73(2):502-7.

399. Jiang J, Lan C, Li L, Yang D, Xia X, Liao Q, Fu W, Chen X, An S, Wang WE, et al. A novel porcupine inhibitor blocks WNT pathways and attenuates cardiac hypertrophy. Biochim Biophys Acta Mol basis Dis. 2018;1864(10):3459-67.

400. Li C, Liang Y, Cao J, Zhang N, Wei X, Tu M, Xu F, Xu Y. The delivery of a Wnt pathway inhibitor toward CSCs requires stable liposome encapsulation and delayed drug release in tumor tissues. Mol Ther. 2019;27(9):1558-67.

401. Madan B, Ke Z, Harmston N, Ho SY, Frois AO, Alam J, Jeyaraj DA, Pendharkar

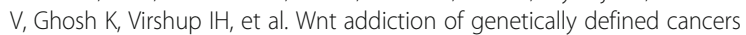
reversed by PORCN inhibition. Oncogene. 2016;35(17):2197-207.

402. Cheng D, Liu J, Han D, Zhang G, Gao W, Hsieh MH, Ng N, Kasibhatla S, Tompkins C, Li J, et al. Discovery of Pyridinyl Acetamide derivatives as potent, selective, and orally bioavailable porcupine inhibitors. ACS Med Chem Lett. 2016;7(7):676-80.

403. Chen B, Dodge ME, Tang W, Lu J, Ma Z, Fan CW, Wei S, Hao W, Kilgore J, Williams NS, et al. Small molecule-mediated disruption of Wnt-dependent signaling in tissue regeneration and cancer. Nat Chem Biol. 2009;5(2):100-7.

404. Leung EY, Askarian-Amiri ME, Sarkar D, Ferraro-Peyret C, Joseph WR, Finlay GJ, Baguley BC. Endocrine therapy of estrogen receptor-positive breast Cancer cells: early differential effects on stem cell markers. Front Oncol. 2017;7:184.

405. Wang X, Moon J, Dodge ME, Pan X, Zhang L, Hanson JM, Tuladhar R, Ma Z, Shi $\mathrm{H}$, Williams NS, et al. The development of highly potent inhibitors for porcupine. J Med Chem. 2013;56(6):2700-4.

406. You L, Zhang C, Yarravarapu N, Morlock L, Wang X, Zhang L, Williams NS, Lum L, Chen C. Development of a triazole class of highly potent Porcn inhibitors. Bioorg Med Chem Lett. 2016;26(24):5891-5.

407. Xu Z, Xu X, O'Laoi R, Ma H, Zheng J, Chen S, Luo L, Hu Z, He S, Li J, et al. Design, synthesis, and evaluation of novel porcupine inhibitors featuring a fused 3-ring system based on the 'reversed' amide scaffold. Bioorg Med Chem. 2016;24(22):5861-72.

408. Jimeno A, Gordon MS, Chugh R, Messersmith WA, Mendelson DS, Dupont J, Stagg RJ, Kapoun A, Xu L, Brachmann RK et al: A first-in-human phase 1 study of anticancer stem cell agent OMP-54F28 (FZD8-FC), decoy receptor for WNT ligands, in patients with advanced solid tumors. Journal of Clinical Oncology 2014, 32(15_suppl):2505-2505.

409. Zeng CM, Chen Z, Fu L: Frizzled Receptors as Potential Therapeutic Targets in Human Cancers. Int J Mol Sci 2018, 19(5).

410. Bendell J, Eckhardt GS, Hochster HS, Morris VK, Strickler J, Kapoun AM, Wang M, Xu L, McGuire K, Dupont J, et al. Initial results from a phase 1a/b study of OMP-131R10, a first-in-class anti-RSPO3 antibody, in advanced solid tumors and previously treated metastatic colorectal cancer (CRC). Eur J Cancer. 2016;69:S29-30

411. Chen M, Wang J, Lu J, Bond MC, Ren XR, Lyerly HK, Barak LS, Chen W. The anti-helminthic niclosamide inhibits Wnt/Frizzled1 signaling. Biochemistry. 2009;48(43):10267-74.

412. Mook RA Jr, Wang J, Ren XR, Chen M, Spasojevic I, Barak LS, Lyerly HK, Chen W. Structure-activity studies of Wnt/beta-catenin inhibition in the
Niclosamide chemotype: identification of derivatives with improved drug exposure. Bioorg Med Chem. 2015;23(17):5829-38.

413. Wang J, Mook RA Jr, Ren XR, Zhang Q, Jing G, Lu M, Spasojevic I, Lyerly HK, Hsu D, Chen W. Identification of DK419, a potent inhibitor of Wnt/betacatenin signaling and colorectal cancer growth. Bioorg Med Chem. 2018; 26(20):5435-42

414. Gurney A, Axelrod F, Bond CJ, Cain J, Chartier C, Donigan L, Fischer M, Chaudhari A, Ji M, Kapoun AM, et al. Wnt pathway inhibition via the targeting of frizzled receptors results in decreased growth and tumorigenicity of human tumors. Proc Natl Acad Sci U S A. 2012;109(29):11717-22.

415. Steinhart Z, Pavlovic Z, Chandrashekhar M, Hart T, Wang X, Zhang X, Robitaille M, Brown KR, Jaksani S, Overmeer R, et al. Genome-wide CRISPR screens reveal a Wnt-FZD5 signaling circuit as a druggable vulnerability of RNF43-mutant pancreatic tumors. Nat Med. 2017;23(1):60-8.

416. Nile AH, de Sousa EMF, Mukund S, Piskol R, Hansen S, Zhou L, Zhang Y, Fu $Y$, Gogol EB, Komuves LG, et al. A selective peptide inhibitor of frizzled 7 receptors disrupts intestinal stem cells. Nat Chem Biol. 2018;14(6):582-90.

417. Nambotin SB, Lefrancois L, Sainsily X, Berthillon P, Kim M, Wands JR, Chevallier M, Jalinot P, Scoazec JY, Trepo C, et al. Pharmacological inhibition of Frizzled-7 displays anti-tumor properties in hepatocellular carcinoma. J Hepatol. 2011;54(2):288-99.

418. Zhang W, Lu W, Ananthan S, Suto MJ, Li Y. Discovery of novel frizzled-7 inhibitors by targeting the receptor's transmembrane domain. Oncotarget. 2017;8(53):91459-70

419. Lee HJ, Bao J, Miller A, Zhang C, Wu J, Baday YC, Guibao C, Li L, Wu D, Zheng JJ. Structure-based discovery of novel small molecule Wnt signaling inhibitors by targeting the cysteine-rich domain of frizzled. J Biol Chem. 2015;290(51):30596-606.

420. Giraudet AL, Cassier PA, Iwao-Fukukawa C, Garin G, Badel JN, Kryza D, Chabaud S, Gilles-Afchain L, Clapisson G, Desuzinges C, et al. A first-inhuman study investigating biodistribution, safety and recommended dose of a new radiolabeled MAb targeting FZD10 in metastatic synovial sarcoma patients. BMC Cancer. 2018;18(1):646.

421. Franco Machado J, Silva RD, Melo R, GC JD. Less Exploited GPCRs in Precision Medicine: Targets for Molecular Imaging and Theranostics. Molecules. 2018;24:1.

422. Lu D, Choi MY, Yu J, Castro JE, Kipps TJ, Carson DA. Salinomycin inhibits Wht signaling and selectively induces apoptosis in chronic lymphocytic leukemia cells. Proc Natl Acad Sci U S A. 2011;108(32):13253-7.

423. Gong X, Azhdarinia A, Ghosh SC, Xiong W, An Z, Liu Q, Carmon KS. LGR5targeted antibody-drug conjugate eradicates gastrointestinal tumors and prevents recurrence. Mol Cancer Ther. 2016;15(7):1580-90.

424. Gupta PB, Onder TT, Jiang G, Tao K, Kuperwasser C, Weinberg RA, Lander ES Identification of selective inhibitors of cancer stem cells by high-throughput screening. Cell. 2009;138(4):645-59.

425. Boolbol SK, Dannenberg AJ, Chadburn A, Martucci C, Guo XJ, Ramonetti JT, Abreu-Goris M, Newmark HL, Lipkin ML, DeCosse JJ, et al. Cyclooxygenase-2 overexpression and tumor formation are blocked by sulindac in a murine model of familial adenomatous polyposis. Cancer Res. 1996:56(11):2556-60.

426. Lee HJ, Wang NX, Shi DL, Zheng JJ. Sulindac inhibits canonical Wnt signaling by blocking the PDZ domain of the protein Dishevelled. Angew Chem Int Ed Engl. 2009;48(35):6448-52.

427. Piazza GA, Alberts DS, Hixson LJ, Paranka NS, Li H, Finn T, Bogert C, Guillen JM, Brendel K, Gross PH, et al. Sulindac sulfone inhibits azoxymethaneinduced colon carcinogenesis in rats without reducing prostaglandin levels. Cancer Res. 1997;57(14):2909-15.

428. Chiu CH, McEntee MF, Whelan J. Sulindac causes rapid regression of preexisting tumors in $\mathrm{min} /+$ mice independent of prostaglandin biosynthesis. Cancer Res. 1997:57(19):4267-73.

429. Grandy D, Shan J, Zhang X, Rao S, Akunuru S, Li H, Zhang Y, Alpatov I, Zhang $X A$, Lang RA, et al. Discovery and characterization of a small molecule inhibitor of the PDZ domain of dishevelled. J Biol Chem. 2009;284(24):16256-63.

430. Choi J, Ma S, Kim HY, Yun JH, Heo JN, Lee W, Choi KY, No KT. Identification of small-molecule compounds targeting the dishevelled PDZ domain by virtual screening and binding studies. Bioorg Med Chem. 2016;24(15):3259-66.

431. Fujii N, You L, Xu Z, Uematsu K, Shan J, He B, Mikami I, Edmondson LR, Neale G, Zheng J, et al. An antagonist of dishevelled protein-protein interaction suppresses beta-catenin-dependent tumor cell growth. Cancer Res. 2007:67(2):573-9. 
432. Shan J, Zhang X, Bao J, Cassell R, Zheng JJ. Synthesis of potent dishevelled PDZ domain inhibitors guided by virtual screening and NMR studies. Chem Biol Drug Des. 2012;79(4):376-83.

433. Kim HY, Choi S, Yoon JH, Lim HJ, Lee H, Choi J, Ro EJ, Heo JN, Lee W, No $\mathrm{KT}$, et al. Small molecule inhibitors of the Dishevelled-CXXC5 interaction are new drug candidates for bone anabolic osteoporosis therapy. EMBO Mol Med. 2016;8(4):375-87.

434. Shan J, Zheng JJ. Optimizing DVI PDZ domain inhibitor by exploring chemical space. J Comput Aided Mol Des. 2009;23(1):37-47.

435. Hwang SY, Deng X, Byun S, Lee C, Lee SJ, Suh H, Zhang J, Kang Q, Zhang T, Westover KD, et al. Direct targeting of beta-catenin by a small molecule stimulates proteasomal degradation and suppresses oncogenic Wnt/betacatenin signaling. Cell Rep. 2016;16(1):28-36.

436. Simonetta KR, Taygerly J, Boyle K, Basham SE, Padovani C, Lou Y, Cummins TJ, Yung SL, von Soly SK, Kayser F, et al. Prospective discovery of small molecule enhancers of an E3 ligase-substrate interaction. Nat Commun. 2019;10(1):1402

437. Thorne CA, Hanson AJ, Schneider J, Tahinci E, Orton D, Cselenyi CS, Jernigan KK, Meyers KC, Hang BI, Waterson AG, et al. Small-molecule inhibition of Wnt signaling through activation of casein kinase 1alpha. Nat Chem Biol. 2010;6(11):829-36

438. Li B, Orton D, Neitzel LR, Astudillo L, Shen C, Long J, Chen X, Kirkbride KC, Doundoulakis T, Guerra ML, et al. Differential abundance of CK1alpha provides selectivity for pharmacological CK1alpha activators to target WNTdependent tumors. Sci Signal. 2017;10:485.

439. Jiang S, Zhang M, Sun J, Yang X. Casein kinase 1alpha: biological mechanisms and theranostic potential. Cell Commun Signal. 2018;16(1):23.

440. Ewan K, Pajak B, Stubbs M, Todd H, Barbeau O, Quevedo C, Botfield H, Young R, Ruddle R, Samuel $L$, et al. A useful approach to identify novel small-molecule inhibitors of Wnt-dependent transcription. Cancer Res. 2010; 70(14):5963-73.

441. Cha PH, Cho YH, Lee SK, Lee J, Jeong WJ, Moon BS, Yun JH, Yang JS, Choi S, Yoon J, et al. Small-molecule binding of the axin RGS domain promotes beta-catenin and Ras degradation. Nat Chem Biol. 2016;12(8):593-600.

442. Park S, Gwak J, Cho M, Song T, Won J, Kim DE, Shin JG, Oh S. Hexachlorophene inhibits Wnt/beta-catenin pathway by promoting Siahmediated beta-catenin degradation. Mol Pharmacol. 2006;70(3):960-6.

443. McGonigle S, Chen Z, Wu J, Chang P, Kolber-Simonds D, Ackermann K, Twine NC, Shie JL, Miu JT, Huang KC, et al. E7449: a dual inhibitor of PARP1/ 2 and tankyrase1/2 inhibits growth of DNA repair deficient tumors and antagonizes Wnt signaling. Oncotarget. 2015;6(38):41307-23.

444. Plummer ER, Dua D, Cresti N, Suder A, Drew Y, Stephens P, Foegh M, Knudsen S, McGonigle S, Ink B, et al. First-in-human phase 1 study of the PARP/tankyrase inhibitor 2X-121 (E7449) as monotherapy in patients with advanced solid tumors and validation of a novel drug response predictor (DRP) mRNA biomarker. J Clin Oncol. 2018;36(15_suppl):2505-5.

445. Lau T, Chan E, Callow M, Waaler J, Boggs J, Blake RA, Magnuson S, Sambrone A, Schutten M, Firestein R, et al. A novel tankyrase smallmolecule inhibitor suppresses APC mutation-driven colorectal tumor growth. Cancer Res. 2013;73(10):3132-44.

446. Voronkov A, Holsworth DD, Waaler J, Wilson SR, Ekblad B, Perdreau-Dahl H, Dinh H, Drewes G, Hopf C, Morth JP, et al. Structural basis and SAR for G007-LK, a lead stage 1,2,4-triazole based specific tankyrase 1/2 inhibitor. J Med Chem. 2013;56(7):3012-23.

447. Coussy F, Lallemand F, Vacher S, Schnitzler A, Chemlali W, Caly M, Nicolas A, Richon S, Meseure D, El Botty R, et al. Clinical value of R-spondins in triplenegative and metaplastic breast cancers. Br J Cancer. 2017;116(12):1595-603.

448. Waaler J, Machon O, Tumova L, Dinh H, Korinek V, Wilson SR, Paulsen JE, Pedersen NM, Eide TJ, Machonova O, et al. A novel tankyrase inhibitor decreases canonical Wnt signaling in colon carcinoma cells and reduces tumor growth in conditional APC mutant mice. Cancer Res. 2012;72(11):2822-32.

449. Waaler J, Machon O, von Kries JP, Wilson SR, Lundenes E, Wedlich D, Gradl D, Paulsen JE, Machonova O, Dembinski JL, et al. Novel synthetic antagonists of canonical Wnt signaling inhibit colorectal cancer cell growth. Cancer Res. 2011;71(1):197-205.

450. Okada-Iwasaki R, Takahashi Y, Watanabe Y, Ishida H, Saito J, Nakai R, Asai A. The discovery and characterization of K-756, a novel Wnt/beta-catenin pathway inhibitor targeting Tankyrase. Mol Cancer Ther. 2016;15(7):1525-34.

451. Narwal M, Koivunen J, Haikarainen T, Obaji E, Legala OE, Venkannagari H, Joensuu P, Pihlajaniemi T, Lehtio L. Discovery of tankyrase inhibiting flavones with increased potency and isoenzyme selectivity. J Med Chem. 2013:56(20):7880-9.

452. Shultz MD, Cheung AK, Kirby CA, Firestone B, Fan J, Chen $\mathrm{CH}$, Chen Z, Chin DN, Dipietro L, Fazal A, et al. Identification of NVP-TNKS656: the use of structure-efficiency relationships to generate a highly potent, selective, and orally active tankyrase inhibitor. J Med Chem. 2013;56(16):6495-511.

453. Kirby CA, Cheung A, Fazal A, Shultz MD, Stams T. Structure of human tankyrase 1 in complex with small-molecule inhibitors PJ34 and XAV939. Acta Crystallogr Sect F Struct Biol Cryst Commun. 2012;68(Pt 2):115-8.

454. Mizutani A, Yashiroda Y, Muramatsu Y, Yoshida H, Chikada T, Tsumura T, Okue M, Shirai F, Fukami T, Yoshida M, et al. RK-287107, a potent and specific tankyrase inhibitor, blocks colorectal cancer cell growth in a preclinical model. Cancer Sci. 2018;109(12):4003-14.

455. Buchstaller HP, Anlauf U, Dorsch D, Kuhn D, Lehmann M, Leuthner B, Musil D, Radtki D, Ritzert C, Rohdich F, et al. Discovery and optimization of 2Arylquinazolin-4-ones into a potent and selective Tankyrase inhibitor modulating Wnt pathway activity. J Med Chem. 2019;62(17):7897-909.

456. James RG, Davidson KC, Bosch KA, Biechele TL, Robin NC, Taylor RJ, Major MB, Camp ND, Fowler K, Martins TJ, et al. WIKI4, a novel inhibitor of tankyrase and Wnt/ss-catenin signaling. PLoS One. 2012;7(12):e50457.

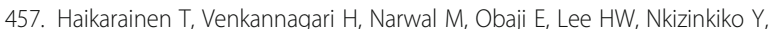
Lehtio L. Structural basis and selectivity of tankyrase inhibition by a Wnt signaling inhibitor WIKI4. PLoS One. 2013;8(6):e65404.

458. Bao R, Christova T, Song S, Angers S, Yan X, Attisano L. Inhibition of tankyrases induces Axin stabilization and blocks Wnt signalling in breast cancer cells. PLoS One. 2012;7(11):e48670.

459. Shetti D, Zhang B, Fan C, Mo C, Lee BH, Wei K. Low Dose of Paclitaxel Combined with XAV939 Attenuates Metastasis, Angiogenesis and Growth in Breast Cancer by Suppressing Wnt Signaling. Cells. 2019;8:8.

460. Manson JE, Cook NR, Lee IM, Christen W, Bassuk SS, Mora S, Gibson H, Gordon D, Copeland T, D'Agostino D, et al. Vitamin D supplements and prevention of Cancer and cardiovascular disease. N Engl J Med. 2019;380(1): 33-44.

461. Arnaout A, Robertson S, Pond GR, Vieth R, Jeong A, Hilton J, Ramsey T, Clemons M. Randomized window of opportunity trial evaluating high-dose vitamin D in breast cancer patients. Breast Cancer Res Treat. 2019:178(2): 347-56.

462. Osawa Y, Oboki K, Imamura J, Kojika E, Hayashi Y, Hishima T, Saibara T, Shibasaki F, Kohara M, Kimura K. Inhibition of cyclic adenosine monophosphate (CAMP)-response element-binding protein (CREB)-binding protein (CBP)/beta-catenin reduces liver fibrosis in mice. EBioMedicine. 2015; 2(11):1751-8.

463. Li J, Wang CY. TBL1-TBLR1 and beta-catenin recruit each other to Wnt target-gene promoter for transcription activation and oncogenesis. Nat Cell Biol. 2008;10(2):160-9.

464. Fiskus W, Sharma S, Saha S, Shah B, Devaraj SG, Sun B, Horrigan S, Leveque C, Zu Y, lyer S, et al. Pre-clinical efficacy of combined therapy with novel beta-catenin antagonist BC2059 and histone deacetylase inhibitor against AML cells. Leukemia. 2015;29(6):1267-78.

465. Cruciat CM, Ohkawara B, Acebron SP, Karaulanov E, Reinhard C, Ingelfinger $D$, Boutros M, Niehrs C. Requirement of prorenin receptor and vacuolar H+-ATPase-mediated acidification for Wnt signaling. Science. 2010; 327(5964):459-63.

466. Minami I, Yamada K, Otsuji TG, Yamamoto T, Shen Y, Otsuka S, Kadota S, Morone N, Barve M, Asai Y, et al. A small molecule that promotes cardiac differentiation of human pluripotent stem cells under defined, cytokineand xeno-free conditions. Cell Rep. 2012;2(5):1448-60.

467. Deshmukh V, Hu H, Barroga C, Bossard C, Kc S, Dellamary L, Stewart J, Chiu K, Ibanez M, Pedraza M, et al. A small-molecule inhibitor of the Wnt pathway (SM04690) as a potential disease modifying agent for the treatment of osteoarthritis of the knee. Osteoarthr Cartil. 2018;26(1):18-27.

468. Chen Z, Venkatesan AM, Dehnhardt CM, Dos Santos O, Delos Santos E, Ayral-Kaloustian S, Chen L, Geng Y, Arndt KT, Lucas J, et al. 2,4-Diaminoquinazolines as inhibitors of beta-catenin/Tcf-4 pathway: potential treatment for colorectal cancer. Bioorg Med Chem Lett. 2009;19(17):4980-3.

469. Tian W, Han X, Yan M, Xu Y, Duggineni S, Lin N, Luo G, Li YM, Han X, Huang $Z$, et al. Structure-based discovery of a novel inhibitor targeting the betacatenin/Tcf4 interaction. Biochemistry. 2012;51(2):724-31.

470. Lepourcelet M, Chen YN, France DS, Wang H, Crews P, Petersen F, Bruseo C, Wood AW, Shivdasani RA. Small-molecule antagonists of the oncogenic Tcf/ beta-catenin protein complex. Cancer Cell. 2004;5(1):91-102. 
471. Hallett RM, Kondratyev MK, Giacomelli AO, Nixon AM, Girgis-Gabardo A, llieva D, Hassell JA. Small molecule antagonists of the Wnt/beta-catenin signaling pathway target breast tumor-initiating cells in a Her2/Neu mouse model of breast cancer. PLoS One. 2012;7(3):e33976.

472. Jang GB, Hong IS, Kim RJ, Lee SY, Park SJ, Lee ES, Park JH, Yun CH, Chung $\mathrm{JU}$, Lee KJ, et al. Wnt/beta-catenin small-molecule inhibitor CWP232228 preferentially inhibits the growth of breast Cancer stem-like cells. Cancer Res. 2015;75(8):1691-702.

473. Gonsalves FC, Klein K, Carson BB, Katz S, Ekas LA, Evans S, Nagourney R, Cardozo T, Brown AM, DasGupta R. An RNAi-based chemical genetic screen identifies three small-molecule inhibitors of the Wnt/wingless signaling pathway. Proc Natl Acad Sci U S A. 2011;108(15):5954-63.

474. Fang L, Zhu Q, Neuenschwander M, Specker E, Wulf-Goldenberg A, Weis WI, von Kries JP, Birchmeier W. A small-molecule antagonist of the betacatenin/TCF4 interaction blocks the self-renewal of Cancer stem cells and suppresses tumorigenesis. Cancer Res. 2016;76(4):891-901.

475. Trosset JY, Dalvit C, Knapp S, Fasolini M, Veronesi M, Mantegani S, Gianellini LM, Catana C, Sundstrom M, Stouten PF, et al. Inhibition of protein-protein interactions: the discovery of druglike beta-catenin inhibitors by combining virtual and biophysical screening. Proteins. 2006;64(1):60-7.

476. Takada K, Zhu D, Bird GH, Sukhdeo K, Zhao JJ, Mani M, Lemieux M, Carrasco DE, Ryan J, Horst D, et al. Targeted disruption of the BCL9/beta-catenin complex inhibits oncogenic Wnt signaling. Sci Transl Med. 2012;4(148):148ra117.

477. Emami KH, Nguyen C, Ma H, Kim DH, Jeong KW, Equchi M, Moon RT, Teo $J$, Kim HY, Moon SH, et al. A small molecule inhibitor of beta-catenin/CREBbinding protein transcription [corrected]. Proc Natl Acad Sci U S A. 2004; 101(34):12682-7.

478. Huss M, Sasse F, Kunze B, Jansen R, Steinmetz H, Ingenhorst G, Zeeck A, Wieczorek H. Archazolid and apicularen: novel specific V-ATPase inhibitors. BMC Biochem. 2005;6:13.

479. Zhang MZ, Ferrigno O, Wang Z, Ohnishi M, Prunier C, Levy L, Razzaque M, Horne WC, Romero D, Tzivion G, et al. TGIF governs a feed-forward network that empowers Wnt signaling to drive mammary tumorigenesis. Cancer Cell. 2015;27(4):547-60.

480. Sellers KJ, Elliott C, Jackson J, Ghosh A, Ribe E, Rojo Al, Jarosz-Griffiths HH, Watson IA, Xia W, Semenov M, et al. Amyloid beta synaptotoxicity is Wnt-PCP dependent and blocked by fasudil. Alzheimers Dement. 2018;14(3):306-17.

481. Ying J, Li H, Yu J, Ng KM, Poon FF, Wong SC, Chan AT, Sung J, Tao Q. WNT5A exhibits tumor-suppressive activity through antagonizing the WNT/ beta-catenin signaling, and is frequently methylated in colorectal cancer. Clin Cancer Res. 2008;14(1):55-61.

482. Safholm A, Leandersson K, Dejmek J, Nielsen CK, Villoutreix BO, Andersson T. A formylated hexapeptide ligand mimics the ability of Wnt-5a to impair migration of human breast epithelial cells. J Biol Chem. 2006;281(5):2740-9.

483. Wang L, Zhang F, Duan F, Huang $R$, Chen X, Ming J, Na J. Homozygous MESP1 knock-in reporter hESCs facilitated cardiovascular cell differentiation and myocardial infarction repair. Theranostics. 2020; 10(15):6898-914

484. Liu B, Zhou J, Wang C, Chi Y, Wei Q, Fu Z, Lian C, Huang Q, Liao C, Yang Z, et al. LncRNA SOX2OT promotes temozolomide resistance by elevating SOX2 expression via ALKBH5-mediated epigenetic regulation in glioblastoma. Cell Death Dis. 2020;11(5):384

485. Mikels AJ, Nusse R. Purified Wnt5a protein activates or inhibits beta-cateninTCF signaling depending on receptor context. PLoS Biol. 2006;4(4):e115.

486. Skvortsova K, lovino N, Bogdanovic O. Functions and mechanisms of epigenetic inheritance in animals. Nat Rev Mol Cell Biol. 2018;19(12):774-90.

\section{Publisher's Note}

Springer Nature remains neutral with regard to jurisdictional claims in published maps and institutional affiliations.

\section{Ready to submit your research? Choose BMC and benefit from:}

- fast, convenient online submission

- thorough peer review by experienced researchers in your field

- rapid publication on acceptance

- support for research data, including large and complex data types

- gold Open Access which fosters wider collaboration and increased citations

- maximum visibility for your research: over $100 \mathrm{M}$ website views per year

At BMC, research is always in progress.

Learn more biomedcentral.com/submissions 